Precht, W.F. and S.L. Miller. 2007. Ecological Shifts along the Florida Reef Tract: The Past is a Key to the Future. In: Geological Approaches to Coral Reef Ecology. R. B. Aronson (Editor). Chapter 9: 237-312. Springer, NY.

\title{
9. Ecological Shifts along the Florida Reef Tract: The Past as a Key to the Future
}

\author{
William F. Precht and Steven L. Miller
}

\begin{abstract}
As it is not in human record, but in natural history, that we are to look for the means of ascertaining what has already been ... in order to be informed of operations which have been transacted in times past ... or to events which are in time to happen.
\end{abstract}

—James Hutton (1785)

\subsection{Introduction}

Does the Quaternary fossil record of Caribbean coral reefs provide an adequate baseline from which a variety of pressing issues and challenges facing modern reefs can be addressed? For more than a decade it has been recognized that the sedimentary and fossil record of Quaternary coral reefs has the potential to help decipher the role of history in the study of living reefs (Jackson 1991, 1992; Jackson, Budd, and Pandolfi 1996). Pandolfi and Jackson (Chapter 8) demonstrate that the predictable patterns of community membership and dominance of acroporid species in the Caribbean throughout the Pleistocene epoch allow for a baseline of pristine coral community composition before human exploitation. Thus, the Pleistocene fossil record of Caribbean reefs provides a clear frame of reference as to what to manage and conserve, and why. Or does it?

\subsection{The Problem}

The ecology of Caribbean and western Atlantic coral reefs has changed dramatically in recent decades and it is now believed that these reefs are in crisis (Rogers 1985; Wilkinson 1993; Ginsburg 1994; Brown 1997; Connell 1997; Eakin et al. 1997; Aronson and Precht 2001a; Gardner et al. 2003). This is especially true along the Florida reef tract (Shinn 1989; Ward 1990; Lidz 1997). But what defines 
the baseline from which we draw conclusions about change? Beginning in the 1950s with the work of the late Thomas F. Goreau and colleagues, it was recognized that typical Caribbean and western Atlantic reefs displayed a generalized zonation pattern with three common species of scleractinian corals as the primary builders of reef framework (Goreau 1959; Glynn 1973; Goreau and Goreau 1973; Kinzie 1973; Ginsburg and James 1974; Bak 1983; Jaap 1984; Hubbard 1988; Graus and Macintyre 1989; Aronson and Precht 2001b). These foundation species include Acropora palmata, A. cervicornis, and the Montastraea annularis species complex. The thickly branching elkhorn coral, A. palmata, was dominant at the reef crest and in the shallowest depths of the fore reef (0-5 m depth; Fig. 9.1A). The more thinly branching staghorn coral, A. cervicornis, was dominant at intermediate depths ( $\sim-25 \mathrm{~m})$ on exposed reefs, and it ranged into shallower habitats on more protected reefs (Adey and Burke 1977; Geister 1977; Hubbard 1988; Fig. 9.1B). The massive corals of the M. annularis species complex (Knowlton et al. 1992, 1997) were (and remain) common in a variety of reef habitats from $<5$ to $>30 \mathrm{~m}$. These Montastraea sibling species commonly exhibit intraspecific changes in morphology along depth gradients revealing broad zonational overlap (Fig. 9.1C). In addition, the branching coral A. prolifera was sometimes found at the interface between the A. palmata and A. cervicornis zones (Fig. 9.1D). The growth and form of this coral is intermediate between the other two Caribbean acroporids and it is most probably a hybrid (Vollmer and Palumbi 2002).

Similarly, Acropora-dominated zonation has been found in Pleistocene and Holocene fossil and subfossil reef deposits throughout the region. These patterns attest to the importance of Acropora spp. in time and space for the Caribbean (Mesolella 1967; Macintyre and Glynn 1976; James, Stern, and Harrison 1977; Geister 1983; Macintyre 1988; Precht and Hoyt 1991; Jackson 1992; Stemann and Johnson 1992; Hubbard, Gladfelter, and Bythell 1994; Greenstein, Harris, and Curran 1998; Aronson and Precht 2001b). However, starting in the late 1970s, and by the early 1980s, the coral zonation pattern dominated by the Acropora spp. had essentially disappeared on many, if not most, Caribbean reefs (Jackson 1991, 1992; Aronson and Precht 2001b,c). Disturbances of various types have been invoked to explain the changing face of Caribbean reefs over the last 25 years with coral mortality, especially mortality of the Acropora spp., being a major driving force in the transition (references in Aronson and Precht 2001b). At the same time, herbivorous fishes have been reduced on some Caribbean reefs by human exploitation, and the herbivorous echinoid Diadema antillarum experienced $>95 \%$ mortality from disease throughout the region in 1983 to 1984 (Hay 1984; Lessios 1988). Coral mortality has in general been followed by the proliferation of fleshy and filamentous (noncoralline) macroalgae, because the reduced populations of these herbivores have not been able to keep pace with algal growth in the vast areas of space opened by the death of corals (Steneck 1994; Aronson and Precht 2000, 2001b; McCook, Wolanski, and Spagnol 2001; Williams and Polunin, 2001; Williams, Polunin, and Hendrick 2001). A question of great significance to scientists, managers, and policymakers is whether the recent changes are something new or part of a long-term pattern of repeated community shifts. 
(A)

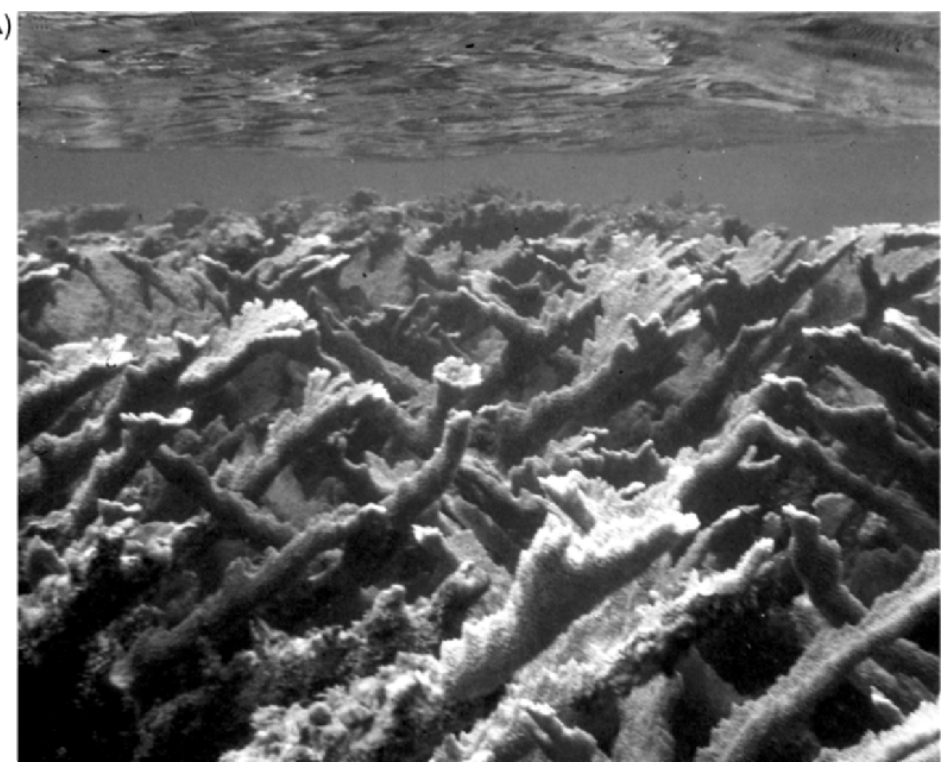

(B)

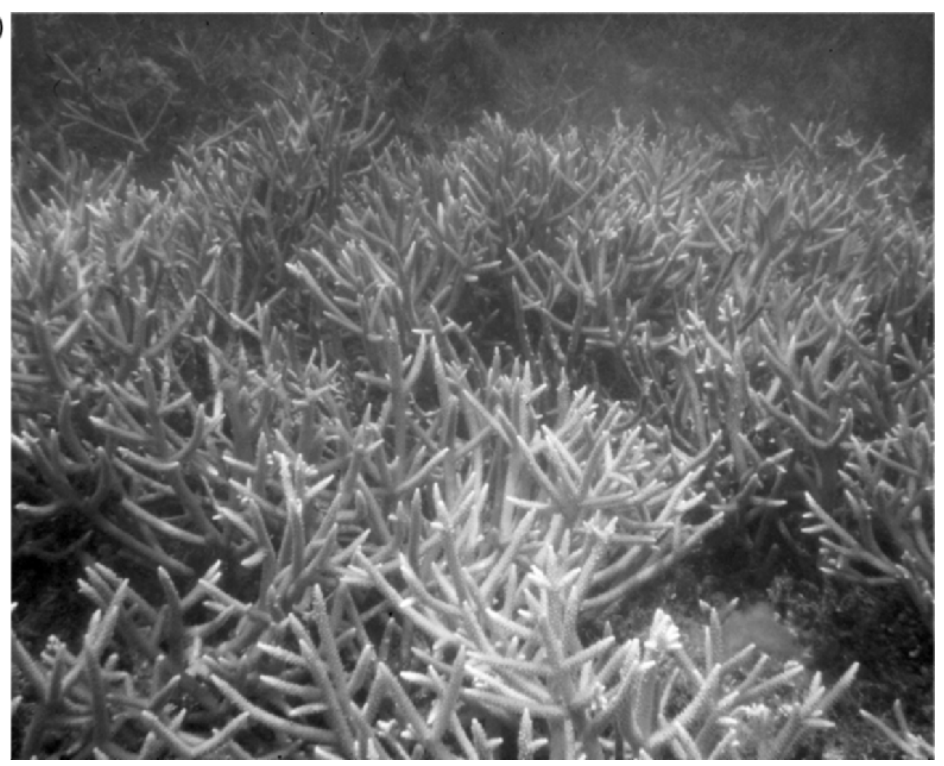

Figure 9.1. (A) Underwater photograph of typical in situ A. palmata forming reef flat prior to the mortality events of the past two decades. Upper horizontal surface of live coral is controlled by growth up to level of spring low tide. (B) Monospecific thicket of the branching coral A. cervicornis at intermediate depths on the fore reef. 
(C)

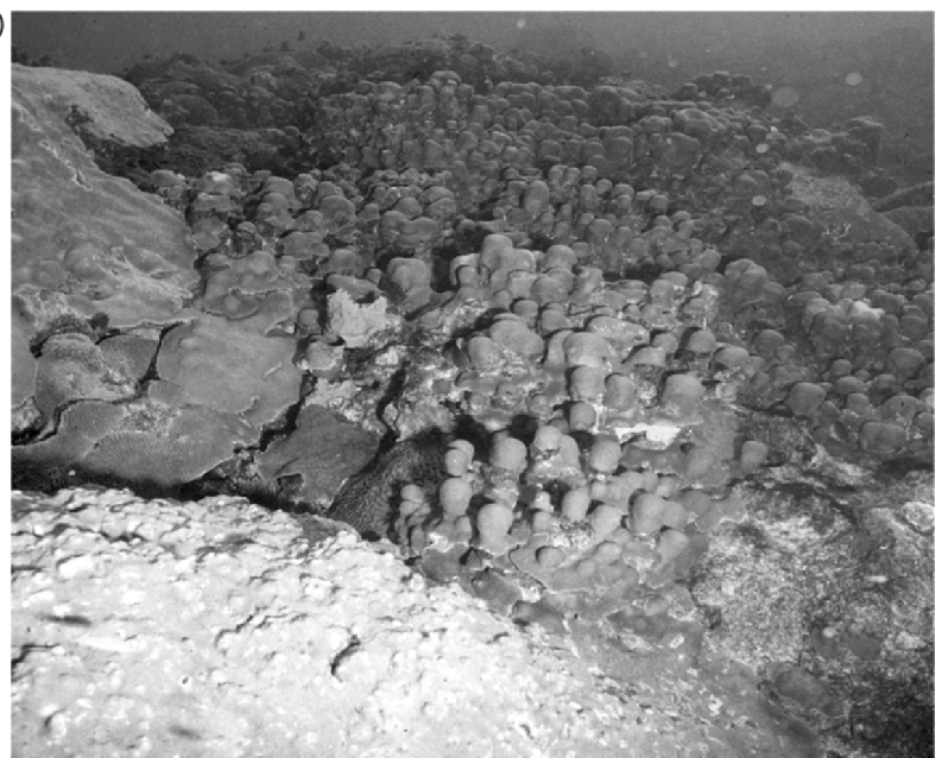

(D)

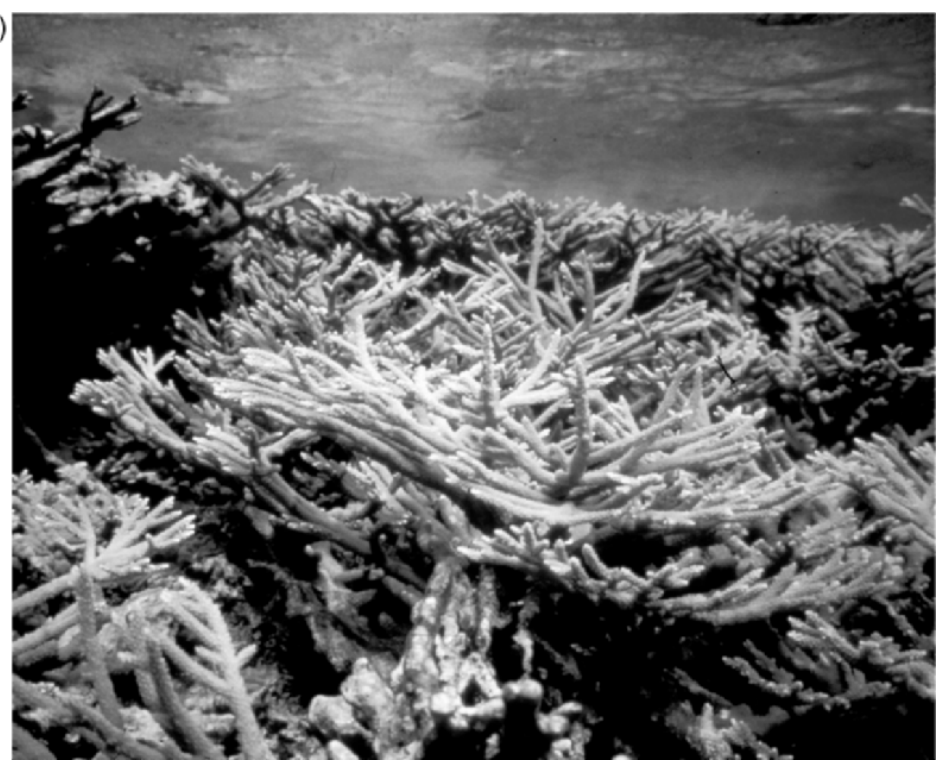

Figure 9.1. (continued) (C) Three common sibling species of the Montastraea annularis complex showing species/habitat overlap including $M$. franksi (lower left), $M$. faveolata (upper left), and $M$. annularis (right). (D) Photograph of A. prolifera at the zonational interface between $A$. palmata and A. cervicornis. 
There are a number of factors responsible for Acropora mortality, with whiteband disease, temperature stress, predation, and hurricanes being some of the most significant at reducing populations both locally and regionally. Corals of the M. annularis species complex have also declined on some reefs throughout the region. Their mortality, however, was caused by factors different from those for the Acropora species (see Aronson and Precht 2001b). In Florida, it is well documented that Acropora-dominated communities are dynamic at the scale of individual reefs and they have been extremely volatile over the past century (Mayer 1902; Shinn 1976; Enos 1977; Davis 1982; Shinn et al. 1989; Jaap and Sargent 1994; Jaap 1998). At the scale of the entire reef tract, deteriorating conditions throughout the late Holocene led to contraction of acroporid reefs and the reef system as a whole. The current regional decline of acroporids, however, appears to be unprecedented in at least the last few thousand years (Aronson and Precht 1997; Aronson et al. 2002a) and possibly longer (Greenstein, Pandolfi, and Curran 1998; Pandolfi and Jackson 2001; but see Rogers et al. 2002; Shinn et al. 2003).

Assessing the novelty of the recent demise of acroporid corals requires a multidisciplinary approach that addresses multiple scales of space and time (Aronson 2001). Because coral reefs are both geologic and biologic entities, it should be possible to observe the effects of various disturbances in ecological time, detect historical changes in the paleoecological record, and deduce the multiscale processes behind those patterns. By comparing and contrasting the structure, anatomy, and biofacies patterns in reef-building episodes of the Pleistocene and Holocene with the living, modern coral reef community, we focused on the question, "How do past ecological responses of coral reef systems, recorded by the fossil record, aid in predicting future response to global change?"

Jackson (1992), Hunter and Jones (1996), Pandolfi (1999, 2002), Pandolfi and Jackson (1997, 2001), and Aronson and Precht (2001b) have shown that, almost without exception, Caribbean Pleistocene fossil-reef sections exhibit species composition and zonation similar to modern reefs at the same location (at least prior to the 1980s). Thus, Pleistocene reef-coral communities within the same environment are more distinct between reefs of the same age from different places than between reefs formed at different times at the same location. Jackson (1992), citing examples from Barbados and other Caribbean locations, concluded that acroporids dominated more or less continuously during the high sea-level stands for the past few hundred thousand years. This concordance of species composition shows that the present clearly is a key to the past. Pandolfi $(2001,2002)$ suggested that the Pleistocene data point to a high degree of order and predictability in Caribbean coral communities over broad spatial and temporal scales. An important result of these studies is that the recent regional demise of the acroporids in the Caribbean and western Atlantic may be without geological precedent and that present trends are not predicted from history, implicating humans as the vector for this change (Stokstad 2001).

There is one major exception to this general pattern, and that is between reefs of the last major interglacial and their Holocene to recent counterparts along the Florida reef tract. In the Pleistocene Key Largo Limestone (Marine Isotope Stage $5 \mathrm{e} ; \sim 125 \mathrm{ka})$, Acropora palmata is absent and there is a paucity of A. cervicornis. 
The Holocene architecture of reefs in the Florida Keys, however, is comprised primarily acroporids (Shinn 1963, 1980, 1984, 1988, 1989; Kissling 1977a; Lighty 1977; Shinn et al. 1981, 1989; Macintyre 1988; Lidz et al. 1997a; Precht et al. 2000). We contend that this temporal difference provides an important clue to understanding the present community configuration along the Florida reef tract. This difference through time also provides essential information to help predict future changes to Florida's reefs in response to environmental perturbations and global change, both natural and anthropogenic.

\subsection{Major Causes of Acropora Mortality: The Roles of Temperature, Inimical Water, Disease, and Hurricanes}

\subsubsection{Temperature and Inimical Water}

Vaughan (1914) recognized that coral reefs in the Florida Keys are at the northern latitudinal limit of extensive reef growth along the Americas (that is, reefs that form high-relief, three-dimensional, complex features constructed by scleractinian corals and coralline algae). Although zooxanthellate corals occur at higher latitudes on both coasts of Florida, only in the Florida Keys do corals construct nearly emergent reef systems (Jaap and Hallock 1990; Fig. 9.2). Temperature has

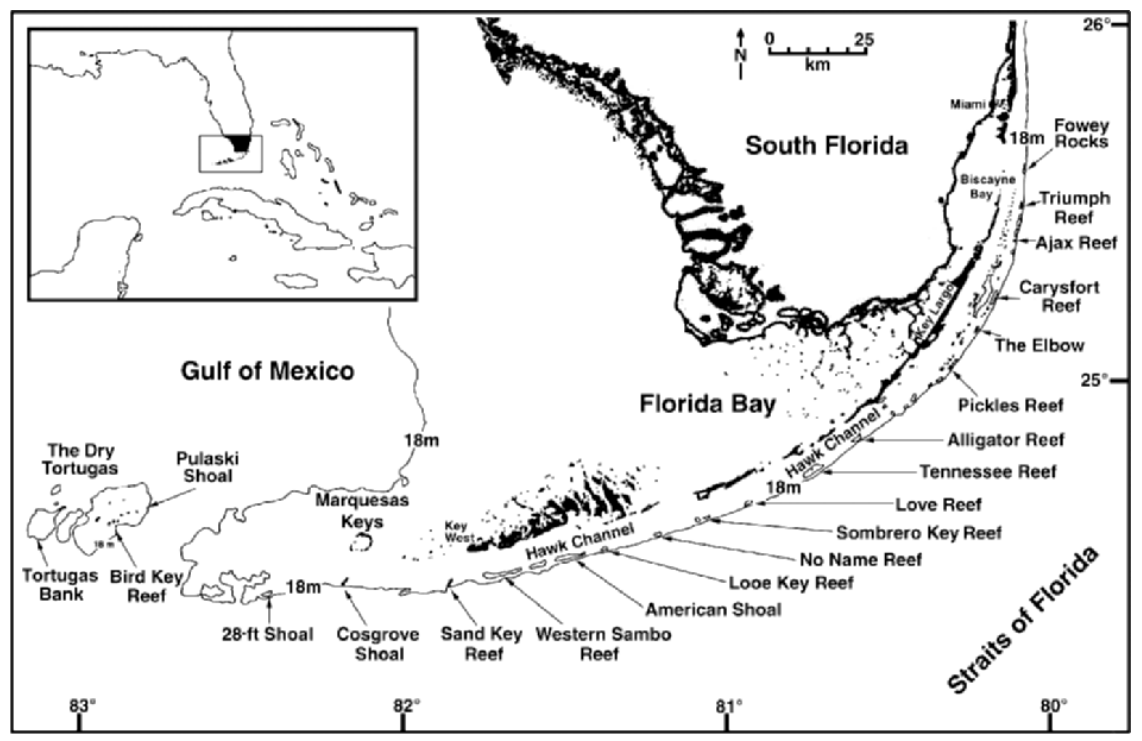

Figure 9.2. Index map of the Florida reef tract from the Dry Tortugas to Fowey Rocks. The named reefs on the map are the discontinuous, nearly emergent reefs that lie seaward of Pleistocene-age islands. Note the large tidal passes between Florida Bay and the open Atlantic in the middle Keys and the paucity of reefs in this area. Modified from Murdoch and Aronson (1999). 
long been considered the main control on reef distribution (Dana 1843; Vaughan 1918,1919 a) with the optimum temperature for coral growth around 26 to $27^{\circ} \mathrm{C}$ (Bosscher 1992). Cold-temperature tolerances are not well defined for corals but early experiments documented $16{ }^{\circ} \mathrm{C}$ as stressful to most corals and exposure to temperatures below $15^{\circ} \mathrm{C}$ can result in their mortality (Mayer 1914, 1915). The present-day global distribution of coral reefs generally coincides with the $18{ }^{\circ} \mathrm{C}$ monthly minimum seawater isotherm (Kleypas, McManus, and Menez 1999; Kleypas, Buddemeier, and Gattuso 2001). South Florida lies between the 18 and $20{ }^{\circ} \mathrm{C}$ isotherm, and shallow coastal waters are especially susceptible to cooling by the passage of cold fronts (Jones 1977; Burns 1985; Walker, Rouse, and Huh 1987). On average, 30 to 40 cold fronts are recorded in south Florida every winter season (Warzeski 1977). Using patterns of generic scleractinian coral diversity, Porter and Tougas (2001) documented rapid faunal diminution northward along the east coast of Florida due primarily to cold-temperature limitations. Historically, Fowey Rocks was the northern extent of true modern reef growth and coral assemblages dominated by the acroporids (Vaughan 1914; Fig. 9.2). Well-developed assemblages of reef-building head corals and octocorals have been described for Broward and Palm Beach Counties (Raymond 1972; Goldberg 1973), and individual colonies of reef-building species have been found as far north as North Carolina (Macintyre and Pilkey 1969). Recently, seven areally limited areas comprising thickets of A. cervicornis were discovered in the waters off Broward County, 50 km north of Fowey Rocks (Vargas-Ángel, Thomas, and Hoke 2003; Precht unpublished data). Although there has been much discussion as to the importance of these isolated coppices (Precht and Aronson 2004), being at the northern edge of acroporid survival and growth make them extremely vulnerable to natural as well as human disturbances.

Ginsburg and Shinn (1964) noted that the major reefs of south Florida occur seaward of islands of Pleistocene limestone. They speculated that the scarcity of thriving reefs opposite the large tidal passes of the Florida Keys is due to reduced water quality moving through the passes (see also Ginsburg and Shinn 1994). These waters are inimical to coral growth and hence to reef development. Newell et al. (1959) proposed a similar model for the depauperate nature of reefs adjacent to the Bahama Banks. Reefs in these areas are said to have been "shot in the back by their own lagoons" (Neumann and Macintyre 1985; Macintyre, Chapter 7).

Follow-up studies and natural abiotic disturbances have supported the inimical waters hypothesis (Marszalek et al. 1977; Shinn et al. 1989; Ginsburg and Shinn 1994; Shinn, Lidz, and Harris 1994; Smith 1994; Ginsburg, Gischler, and Kiene 2001; Cook et al. 2002; Lee et al. 2002; Smith and Pitts 2002). Specifically, Roberts et al. (1982) and Roberts, Wilson, and Lugo-Fernandez (1992) used satellite infrared spectral data and in situ water temperature measurements to identify plumes of cold $\left(<16^{\circ} \mathrm{C}\right)$, sediment-laden water flowing through the tidal passes for eight consecutive days in the winter of 1977, associated with the passage of three successive and unusually severe cold fronts (Fig. 9.3). The lowest measured water temperature in the middle Florida Keys during this period was $9{ }^{\circ} \mathrm{C}$ (Hudson 1981a). These prolonged cold temperatures proved lethal to hundreds 


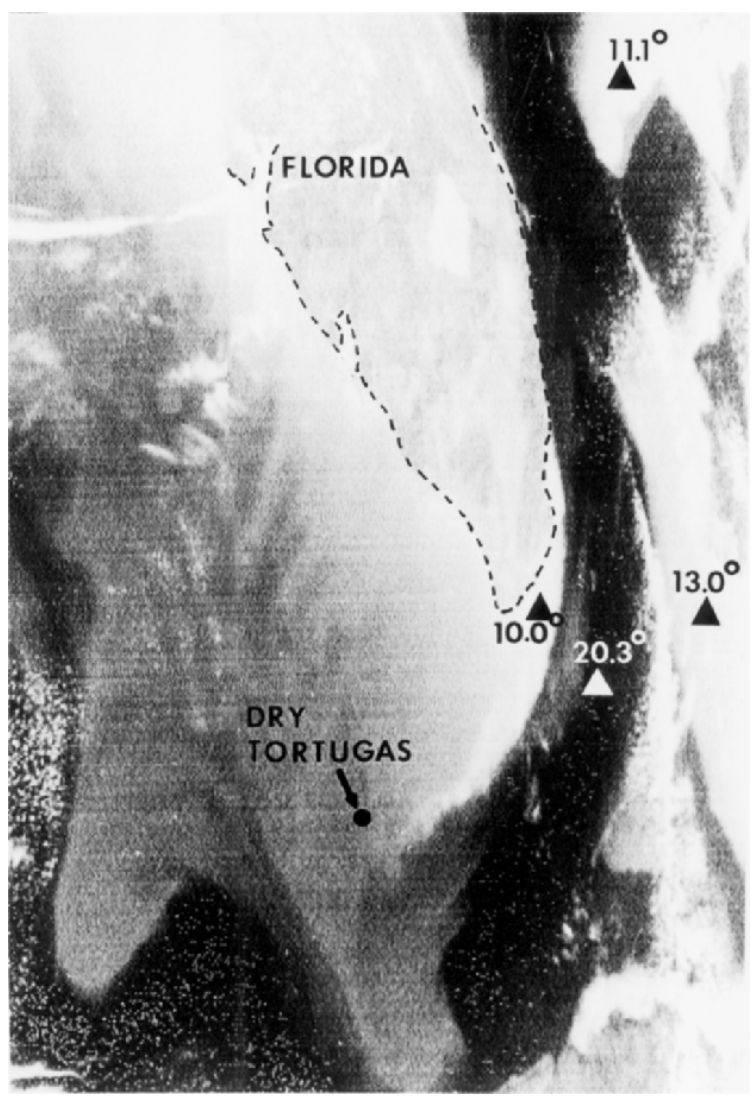

Figure 9.3. Satellite infrared image showing plumes of cold and turbid water flowing onto the reef tract in the lower Keys following the passage of numerous successive cold fronts in January 1977. Temperatures of inshore waters were $\sim 10^{\circ} \mathrm{C}$ cooler than waters in the Gulf Stream. Vast areas of acroporid-dominated reefs were killed during this event. Image courtesy of Harry Roberts.

of square kilometers of A. palmata and A. cervicornis (Davis 1982; Porter, Battey, and Smith 1982; Walker et al. 1982; Roberts, Rouse, and Walker 1983; Shinn 1989). In retrospect, this was not surprising, as coral translocation experiments moving A. cervicornis to inshore positions showed that the coral was killed outright when the water temperature fell to $13.3{ }^{\circ} \mathrm{C}$ (Shinn 1966, 1989). It has also been shown that A. palmata is equally sensitive to cold temperatures (Antonius 1977; Macintyre 1988; Shinn et al. 1989; Jaap and Sargent 1994).

In the Dry Tortugas, cold fronts have dramatically reduced acroporid populations at least twice in the last century (Jaap and Hallock 1990; Jaap and Sargent 1994). During the cold-water event of 1977 described above, the Dry Tortugas lost 96\% of corals surveyed (Porter, Battey, and Smith 1982). Shinn (1984) specifically attributed the late Holocene reduction of living coral in the middle 
and lower Keys, especially A. palmata and A. cervicornis, to frequent exposure to cold water from the Gulf of Mexico during winter months. In the northern Keys, Burns (1985) described conditions east of Biscayne Bay as generally suboptimal for coral growth, due to cold-water flow from tidal passes out of the bay, with shallower-water sites affected more than deeper reefs. Cold fronts cause the loss of sensible and latent heat of the shallow bank and bay waters, resulting in advection and off-bank transport of superchilled water masses (Walker et al. 1982; Roberts, Rouse, and Walker 1983). Murdoch and Aronson (1999) showed that reefs adjacent to large tidal passes exhibited particularly low coral cover (e.g., Sombrero Key Reef), whereas reefs opposite large islands (e.g., American Shoal and Alligator Reef) had higher coral cover. However, all reefs in their study showed significantly diminished coral populations, especially the acroporids, when compared to historical observations. Lighty, Macintyre, and Neumann (1980) inferred that similar stress conditions introduced by the off-bank transport of turbid and episodically cooled waters led to the demise of the Acropora-dominated Abaco reef system in the Bahamas between 3000 and 4000 years ago. Following the mortality of the acroporids, the shallow Abaco reef system converted to an alternative community state dominated by macroalgae that persists to this day (Lighty 1981; Conrad Neumann personal communication).

The response of coral reefs to maximum temperature is less clear, but elevated water temperatures can be equally detrimental to corals (Mayer 1918). Bleaching, the loss of algal symbionts is a response to a number of potential stresses (Williams and Bunkley-Williams 1990). These stresses vary regionally and seasonally, and they may act singly or synergistically to cause corals to bleach (Fitt et al. 2001). The most obvious is temperature-induced stress. Corals are typically exposed during local summertime to temperatures near the upper limits of their thermal tolerances (Jokiel and Coles 1990; Glynn 1993; Hoegh-Guldberg 1999); therefore, coral reefs are often considered to be the ecosystems most threatened by global warming (Glynn 1996; Hoegh-Guldberg 1999; Kleypas et al. 1999; Walther et al. 2002). Field and laboratory studies have shown unequivocally that sustained, anomalously high summer water temperatures are associated with coral reef bleaching (Glynn and D'Croz 1990; Podestá and Glynn 1997, 2001) and, if temperatures are elevated above the average maximum for a prolonged period, many species die (Mayer 1918; Glynn 1983; Aronson et al. 2002b). Coral bleaching in response to anomalously high summer-season temperatures has become more frequent since the early 1980s (Glynn 1991, 1993; Hoegh-Guldberg 1999; Aronson et al. 2000; Lough 2000; Williams and Williams 2000; Kleypas, Buddemeier, and Gattuso 2001; Wellington et al. 2001) with the earliest known bleaching event in Florida having occurred in 1973 (Jaap 1979). Causey (2001) documented at least seven bleaching episodes along the Florida reef tract since then. The increased and widespread nature of these coral bleaching events over the past two decades is convincingly correlated with increases in maximum sea surface temperature (Kleypas, Buddemeier, and Gattuso 2001). Bleaching is not always fatal, and some bleaching episodes on reefs in Florida have been followed by recovery of most of the affected coral colonies (Jaap 1985; Porter et al. 1989; 
Williams and Bunkley-Williams 1990; Lang et al. 1992; Fitt et al. 1993). Because the Acropora species live in relatively shallow water, it is thought that they may be tolerant of, or acclimatized to, warm summertime temperatures. Shinn (1966) recognized that the growth for A. cervicornis was greatest when temperatures ranged between 28 and $30^{\circ} \mathrm{C}$. However, Shinn (1966) described bleaching in A. cervicornis when transplanted in water temperatures above $31^{\circ} \mathrm{C}$. Bleachingrelated mortality of Acropora has been observed in Costa Rica (Cortés et al. 1984), Belize (Kramer and Kramer 2000), and the Florida Keys and the Bahamas (Causey et al. 1998; Miller et al. 2002; Precht unpublished data from the summer/fall of 1998).

The inimical-waters explanation of Ginsburg and Shinn (1964) may also be rooted in pulses of high-temperature water flowing through the tidal passes (Porter, Lewis, and Porter 1999). Shallow, lagoonal waters equilibrate rapidly with the atmosphere relative to the more deeply mixed oceanic waters that front the reef (Neumann and Macintyre 1985). Therefore, it is likely that at peak summertime temperatures waters in excess of $32{ }^{\circ} \mathrm{C}$ are commonly discharged from the Gulf of Mexico, Florida Bay, and Biscayne Bay onto the reefs of the Florida Keys (Ginsburg and Shinn 1994; Ogden et al. 1994). Global warming will probably exacerbate the situation (Hoegh-Guldberg 1999; Walther et al. 2002).

\subsubsection{White-Band Disease}

Although the effects of temperature are important at the scale of reef systems, it is becoming apparent that for more than two decades white-band disease (WBD) epizootics have been the primary cause of Acropora mortality over wide areas of the Caribbean and western Atlantic (Bythell and Sheppard 1993; Aronson and Precht 2001b,c), including Florida (Shinn 1989; Precht and Aronson 1997), with losses in excess of 95\% regionally (Precht et al. 2002). Robinson (1973), reporting on the reef condition of Buck Island National Monument in the U.S. Virgin Islands, was the first to discuss mortality related to WBD. Subsequently, Gladfelter (1982) recognized the devastating effects of WBD on coral reef community structure. Wells and Hanna (1992) noted anecdotally that acroporids from the Florida reef tract had up to $96 \%$ of reef cover in places in 1981. By 1986 these corals had succumbed to disease and were reduced to only $3 \%$ of the total reef cover. Jaap, Halas, and Muller (1988) measured a 96\% decline in A. cervicornis at Molasses Reef in the Florida Keys National Marine Sanctuary (FKNMS) during this same period. Gleason (1984) reported that by 1982 the acroporids had been exterminated on a large portion of the Florida reef tract, supporting a case for their complete protection (Antonius 1994a,b). Quantitative evidence reveals that the coverage of remnant A. palmata declined by $93 \%$ and A. cervicornis by $98 \%$ between 1983 and 2000 at Looe Key (Miller et al. 2002). Photographic evidence from Shinn shows that mass mortality of A. cervicornis at Grecian Rocks in the upper FKNMS occurred during 1978 to 1979 with complete loss by 1983 (in Miller 2002). Before-and-after photographs in Ward (1990) also emphasize the dramatic and devastating effects of coral death related to WBD in the 
Florida Keys. These various reports suggest that the 1960s and early 1970s may represent a baseline for the status of "healthy" acroporid populations in Florida and the Caribbean (Kramer 2002).

Even after 20 years, the etiology of the WBD epizootic remains unknown, and recent reports reveal that there may be multiple varieties of the disease (or white syndromes) with differing characteristics and pathologies (Antonius 1981; Gladfelter 1982; Peters, Yevich, and Oprandy 1983; Peters and McCarty 1996; Peters 1997; Santavy and Peters 1997; Richardson 1998; Ritchie and Smith 1998; Richardson and Aronson 2002). WBD can generally be recognized as areas of bare skeleton, sometimes bordered by narrow bands of disintegrating, necrotic coral tissue, on otherwise healthy-looking, golden-brown Acropora branches. The disease spreads rapidly along the branches, usually from base to tip. The branches initially turn white and are quickly covered with a microalgal turf. The rapidly killed colonies are often left standing in growth position; in time they are broken and reduced to coral rubble by both physical and biological processes. Dead stands of Acropora are especially susceptible to breakage and transport during major storms (Hubbard et al. 1991). The resulting low-relief fields of Acropora rubble are then overgrown by replacement species, usually macroalgae (McClanahan et al. 1999). There is no association of WBD outbreaks with proximity to human influences; reefs both near and far from human population centers have been affected (Aronson and Precht 2001c). Of course, it could be argued that the Caribbean is so small that the entire region lies in close proximity to sources of anthropogenic stress (Hallock, Muller-Karger, and Halas 1993; Connell 1997; Roberts 1997; Miller and Crosby 1999; Jackson 2001; Andréfouët et al. 2002). Based on the results of coring Holocene reefs in Belize, Aronson and Precht (1997; see also Aronson et al. 2002a; Aronson and Ellner, Chapter 3) have shown that the regional mass mortality of the acroporids due to WBD was a novel event in at least the last $3 \mathrm{ky}$.

\subsubsection{Hurricanes}

As previously mentioned, local populations of Acropora palmata and A. cervicornis can be highly variable on a time scale of decades to centuries (Shinn et al. 1989; Jaap 1998). Both species experienced significant mortality from hurricanes and other severe storms in the past as they have recently (Glynn, Almodóvar, and González 1964; Ball, Shinn, and Stockman 1967; Hubbard 1988; Blanchon, Jones, and Kalbfleisch 1997). In fact, these studies and others have led to the opinion that hurricanes are a primary cause of present and past coral mortality, diversity, and distribution on Caribbean reefs (Connell 1978; Porter et al. 1981; Rogers 1993a; Aronson and Precht 1995; Blanchon 1997; and many others). Some areas, such as Costa Rica and Panama, receive virtually no hurricanes while others, including the Florida reef tract, suffer from regular hurricane damage (Ball, Shinn, and Stockman 1967; Perkins and Enos 1968; Neumann et al. 1993; Treml, Colgan, and Keevican 1997). Although hurricanes have been important at some localities (e.g., Stoddart 1963; Woodley et al. 1981; Graus, Macintyre, and 
Herchenroder 1984; Hubbard et al. 1991; Lugo, Rogers, and Nixon 2000; Gardner et al. 2005), they do not explain recent patterns of coral mortality in much of the Caribbean region, including Florida.

Historical records of hurricanes in south Florida reliably date to 1871, with several trends of increased and decreased frequency apparent (Gentry 1984; Neumann et al. 1993). A large number of hurricanes struck the Florida Keys between 1910 and 1948, decreasing significantly over the next 50 years. In 1960 and 1965, Hurricanes Donna and Betsy struck the upper Keys but caused substantial damage to only a few reefs (Ball, Shinn, and Stockman 1967; Perkins and Enos 1968). Recovery was rapid after Hurricanes Donna and Betsy, with little evidence of storm effects present after one year and total recovery within five and three years, respectively (Shinn 1976). Two storms, Hurricane Andrew in 1992 and the March Storm of the century in 1993, caused different patterns of damage within the same reef system, suggesting that disturbance history is an important factor determining reef condition and resilience (Precht et al. 1993; Lirman and Fong 1997). Also, after Hurricane Andrew, 19 hard-bottom sites north of Miami revealed no pattern of damage relative to location, orientation, or depth (Blair, McIntosh, and Mostkoff 1994). In 1998, Hurricane Georges affected reefs of the lower and middle Keys. On the reef at Looe Key, the resulting damage included the nearelimination of remnant stands of Acropora spp. (Porter and Tougas 2001; Miller, Bourque, and Bohnsack 2002; WFP and SLM personal observations). Miller et al. (2002) commented that even in the upper Keys there was some mortality to remnant stands of A. palmata from this storm. Results from 12 reefs sampled before and six weeks after Hurricane Georges revealed that changes in the percent cover of hard corals varied among sites (Miller and Swanson 1999).

The effects of hurricanes in the Florida Keys over the last 50 years can be considered minimally important at the regional scale, but probably important at the scale of individual reefs (see Bythell, Hillis-Starr, and Rogers 2000). Significantly, the recent period of Acropora decline in Florida (the late 1970s to early 1980s) was coincident with an extended period of no major hurricanes. In addition, under all but the most extreme conditions, hurricanes can be favorable to the propagation and expansion of acroporid-dominated communities by asexual reproduction of storm-induced fragments (Shinn 1966, 1976; Gilmore and Hall 1976; Highsmith, Riggs, and D'Antonio 1980; Tunnicliffe 1981; Highsmith 1982; Fong and Lirman 1995; Lirman and Fong 1997; Lirman 2000; Precht et al. 2005a). It appears that, on a regional basis at least, corals suffer greater damage from chronic disturbances and stresses such as disease outbreaks (Shinn 1989; Bythell, Gladfelter, and Bythell 1993; Rogers 1993b; Bythell, Hillis-Starr, and Rogers 2000; Aronson and Precht 2001b,c; Precht et al. 2002).

\subsubsection{Other Causes of Acropora Mortality}

In Florida, Enos (1977) noted that on reefs close to Key West, spatial variability in reef vitality was random between reefs under similar physiographic and hydrodynamic settings. Specifically, he detailed a flourishing, healthy A. palmata reef 
assemblage at Sand Key reef, while at Rock Key about $2 \mathrm{~km}$ away the reef comprised totally dead in situ stands of A. palmata. What was responsible for the complete extirpation of $A$. palmata at Rock Key? In hindsight a disease epizootic or pest outbreak seems a likely cause. Enos (1977), commenting on these enigmatic observations made in the 1960s and early 1970s, stated, "The many dead reefs along the Florida shelf edges may attest to similar mass mortality rather than to creation of conditions continually unfavorable for reef growth." Unfortunately, we have neither premortality baselines for these reefs, nor before-during-and-after monitoring, limiting our ability to assign causality. At local scales, additional causes of acroporid mortality include cultural eutrophication (Weiss and Goddard 1977; Tomascik and Sander 1987; Bell and Tomascik 1994), predation by corallivores (Bak and van Eys 1975; Antonius 1977; Kaufman 1977; Tunnicliffe 1983; Knowlton, Lang, and Keller 1988, 1990; R. Bruckner, Bruckner, and Williams 1997; Miller 2001; Baums, Miller, and Szmant 2003), and sedimentation (Rogers 1983, 1990; Cortés 1994; Peters and McCarty 1996).

Jackson et al. (2001) and Jackson (2001) indicated that overgrowth by macroalgae following the mass mortality of Diadema antillarum was the main process responsible for the sudden and catastrophic mortality of the Caribbean corals during the 1980s. Based upon the timeline of disturbances in the Caribbean, however, this sequence of events is not possible. The rapid decline of Acropora in the late 1970s and early 1980s predated the mass die-off of the herbivorous urchin D. antillarum in 1983 to 1984 , which in turn triggered dramatic increases in the abundance of the macroalgae on which they graze. While some mortality of head corals can be attributed to overgrowth by macroalgae, it is our contention that coral mortality itself was the crucial precursor to macroalgal dominance (discussed in Aronson and Precht 2001b; see also Lirman 2001). This is especially so for rapidly growing species like the Acropora, which can outcompete algae for space and light (Jackson 1991).

Understanding the causes of recent coral mortality as well as the resulting patterns of community variability along the Florida reef tract allows us to develop a better understanding of the processes and products preserved in their Quaternary fossil counterparts. Using analogy-based models, we will shuttle back and forth between the ancient and the modern to develop a picture of the changing face of Floridian reefs through time and space. Our comparative examples will, in turn, aid in predicting the future of Florida's reefs in an era of rapid ecological change and the impact of man.

\subsection{The Quaternary History of Reef Building in the Florida Keys}

\subsubsection{The Pleistocene Reef System}

The Key Largo Limestone was originally named by Sanford (1909). It crops out in an arcuate pattern, forming the present-day islands of the upper and middle Florida Keys. The exposure extends in a discontinuous fashion from Soldier Key 
in the northeast for approximately $170 \mathrm{~km}$ to the southwest, terminating at the Newfound Harbor Keys. The entire Pleistocene section is of variable composition and consists of at least five punctuated stratigraphic units (parasequences) separated by unconformity surfaces (Perkins 1977; Multer et al. 2002a). These units record the major Pleistocene high-stands of sea level on the south Florida Peninsula. Reef development in the earliest Pleistocene (Q1-Q2 units of Perkins) was restricted to the tops of a few bathymetric highs (Multer et al. 2002a). Reefs developed in earnest during MIS 9 (Q3 unit of Perkins) forming a bank-barrier reef system dominated by fused massive corals (Multer et al. 2002a). These Q3 bank-barrier reefs formed at the shelf break on a broad platform and provided the templates for late Pleistocene reef growth (Q4-Q5 units of Perkins). (Age determinations for the Q1-Q4 units and assignments of Marine Isotope Stages are based on amino acid diagenesis of fossil Mercenaria bivalves (Mitterer 1974).)

The unit that is the focus of this chapter is confined to the uppermost exposed portions of the Key Largo Limestone and was originally described by Agassiz (1896). These exposed sections are equivalent to the Q5 unit of Perkins (1977). The reefs were formed during the last major interglacial high sea-level stand (MIS 5e) and are equivalent to and transitional with the oolitic facies of the Miami Limestone (Coniglio and Harrison 1983; Kindinger 1986; Evans 1987; Shinn et al. 1989). Age determinations for this unit give an estimate of between 120 and 135 ka (Broecker and Thurber 1964; Osmund, Carpenter, and Windom 1964; Muhs et al. 1992; Fruijtier, Elliott, and Schlager 2000). Evidence for at least two separate sea-level peaks during MIS 5e have been documented throughout the Caribbean including south Florida (Muhs et al. 1992; Precht 1993; Neumann and Hearty 1996; White, Curran, and Wilson 1998; Fruijtier, Elliott, and Schlager 2000). The local maximum sea level during MIS 5e has been calculated at $\sim 7 \mathrm{~m}$ above present (Randazzo and Halley 1997; Lidz 2000a,b) and is in close correlation with the elevation of $7.5 \pm 1.5 \mathrm{~m}$ proposed by Cronin et al. (1981) for the U.S. Atlantic Coastal Plain. This also corresponds with an elevation of $6 \pm 1 \mathrm{~m}$ measured along the north coast of Jamaica (Precht 1993). The maximum elevation of the Key Largo Limestone is presently found on Windley Key; the top surface of this formation is slightly less than $6 \mathrm{~m}$ above sea level (Halley, Vacher, and Shinn 1997). Where the elevated portions of the Key Largo Limestone are penetrated by mechanical methods (quarrying, canal cuts, marina excavations, mosquito ditches, building foundations, and core borings) they reveal the presence of a coral-rich, reefal limestone (Pasley 1972; Hodges 1977; Harrison, Cooper, and Coniglio 1984; Multer et al. 2002a).

All the coral species present in these limestones are found living today in the waters of the Florida reef tract (Stanley 1966). However, not all of the corals living today are present in the Key Largo Limestone (Hoffmeister et al. 1964). Specifically, there is an absence of A. palmata, a paucity of A. cervicornis, and dominance by an assemblage of $M$. annularis, Diploria strigosa, and Porites astreoides. Stanley (1966) commented that there is a fortuitous juxtaposition of these Pleistocene deposits with the recent, offering a special opportunity for application of the principle of uniformitarianism. Nevertheless, inferences drawn 
from comparison of modern and ancient reefs can give rise to misleading or incorrect interpretations, confounding our understanding of reef systems and hindering our ability to decipher the real story locked in the rocks (Wood 1999). Specifically, the time-averaged and incomplete nature of both the fossil and stratigraphic records may limit direct translation between the modern and ancient (Roy et al. 1996; Greenstein, Curran, and Pandolfi 1998; Pandolfi 2002; Shinn et al. 2003). Also, not all corals stand the same chance of preservation in the fossil record further confounding interpretations (Hubbard, Gladfelter, and Bythell 1994; Pandolfi 2002). Finally, having an understanding of paleogeographic setting is an important component to the application of uniformitarianism-based analogies. Interestingly, several different and contrasting explanations exist that describe the environment of formation of the exposed, coral-rich unit of the Pleistocene Key Largo Limestone. The most important aspect of the various explanations is reconciliation of the absence of A. palmata in the Pleistocene with an abundance of A. palmata in the Recent (the last $10 \mathrm{ka}$ ).

Six hypotheses have been developed for the Q5 unit (MIS 5e) of the Key Largo Limestone.

Hypothesis 1: The reefs grew in deeper water (water depths 6-12 m) dominated by Montastraea annularis and formed a broad and homogeneous coral plantation on the east Florida shelf but at some distance inside the shelf margin (Stanley 1966). Hypothesis 2: The deposit represents an arcuate series of coalesced low-energy patch reefs, dominated by $M$. annularis and located shoreward of an active acroporid-dominated barrier reef on a broad carbonate shelf (Hoffmeister and Multer 1968; Hoffmeister 1974; Friedman 1977; Hodges 1977; Jones 1977; Multer 1977; Greenstein and Pandolfi 1997; Greenstein, Pandolfi, and Curran 1998).

Hypothesis 3: Linear concentrations of lagoonal back-reef corals grew along the edge of an elongate, submerged, antecedent high (Dodd, Hattin, and Liebe 1973).

Hypothesis 4: The shelf-margin sand-shoal complex known as White Bank, and associated inner-shelf patch reefs, are the modern-day analogy for the exposed Key Largo Limestone (Perkins 1977). Similar shelf-margin sand shoals and patch reefs migrated landward during Pleistocene (Q5) sea-level rise and did not require a seaward reef barrier for their inception. At sea-level maximum, the leading shallowest edge of the transgressive unit was preserved as an arcuate patch-reef and skeletal-sand complex.

Hypothesis 5: Numerous shallow-water patch reefs developed over an antecedent bathymetric high (the Northern Keys High), with associated skeletal grainstones, packstones, and wackestones. From this topographic high, the limestone dips steeply seaward, suggesting a sloping, ramp-type, carbonate shelf (Multer et al. 2002a,b).

Hypothesis 6: A concentric rim of shallow-water reefs dominated by M. annularis formed a bank-barrier complex. The bank-barrier complex separated a vast, shallow, carbonate platform dominated by bryozoan-rich skeletal packstones with localized lagoonal patch-reefs to the west (Gulf of Mexico), from a broad, coral-studded shelf to the east (Shinn et al. 1977, 1989; Shinn 1984, 1988; Harrison and Coniglio 1985; Textoris, Fuhr, and Merriam 1989; Halley, Vacher, and Shinn 1997). 
Testing these hypotheses requires a careful evaluation of the chronostratigraphy and biofacies in relation to the known sea-level history during Key Largo time (MIS 5e):

Hypothesis 1: Stanley (1966) described the exposed MIS 5e Key Largo reef limestones as having a deep-water (6- to 12-m) origin. He based this interpretation on the absence of shallow-water A. palmata and an abundance of head corals, including large M. annularis colonies. Stanley (1966) emphasized that "the lack of zonation ... and the apparent homogeneity of the entire Key Largo reef mass indicate that no significant energy gradient existed during reef growth." An excellent deeper-water modern counterpart exists in the Diploria-Montastraea-Porites zone on the reefs of the Flower Garden Banks in the Gulf of Mexico (Bright et al. 1984; Gittings et al. 1992). Recently, Lidz, Reich, and Shinn (2003) discussed the possibility that the "corals of the Key Largo Limestone prefer low-energy conditions and generally grow in water deeper than $5 \mathrm{~m} . "$

These deeper-water interpretations can be falsified based on the position of the exposed Key Largo Limestone relative to the known sea-level maximum. The maximum paleo-water depths for the corals can be calculated by taking the difference between the maximum sea-level elevation $(+7 \mathrm{~m})$ and the elevation of the coral biofacies in question (+1-6 m). For Stanley's deeper-water (6-12 m depth) hypothesis to be correct, either neotectonic uplift or a MIS 5e high stand of at least $18 \mathrm{~m}$ above present sea level would be required. Furthermore, numerous corals exposed in outcrop are flat-topped or have developed "micro-atoll" morphology as a response to growth up to the mean level of spring low tide (Fig. 9.4; see Stoddart and Scoffin 1979). Based on this evidence, most corals in the Key Largo Limestone must have formed in waters $\sim 1$ to $5 \mathrm{~m}$ deep. These reefal deposits are also stratigraphically equivalent to and interfinger with the exposed oolitic shoal facies of the Miami Limestone negating the deeper-water interpretation (Halley and Evans 1983; Kindinger 1986). The evidence for a relatively shallow-water origin is clear, but the interpretation of shelf setting and physical environmental regimes is not.

Hypothesis 2: Hoffmeister and Multer (1968) postulated that the Key Largo Limestone represents a series of low-energy patch reefs that formed in a back-reef environment. They based this hypothesis on the high-energy conditions favorable for the growth of A. palmata. They argued that A. palmata is not a common biotic constituent on most modern-day patch reefs in the Florida Keys and that its absence in the Key Largo Limestone, therefore, demands a low-energy interpretation. This interpretation requires that a high-energy reef-crest community dominated by acroporids lie somewhere seaward on the outer margin of the Key Largo platform. They knew that to substantiate this interpretation they had to prove that this hypothetical outer reef existed (see Hoffmeister 1974). In the 1960s Hoffmeister and Multer drilled a series of deep cores throughout the Florida Keys to test and refine their facies model. Using a core boring drilled through the rear zone behind the crest of the present-day reef at Looe Key, they encountered what was believed to be an A. palmata-bearing Pleistocene limestone at $\sim 17 \mathrm{~m}$ below present sea level (Multer and Hoffmeister 1977; also reported in Halley, Vacher, and Shinn 1997). 
(A)

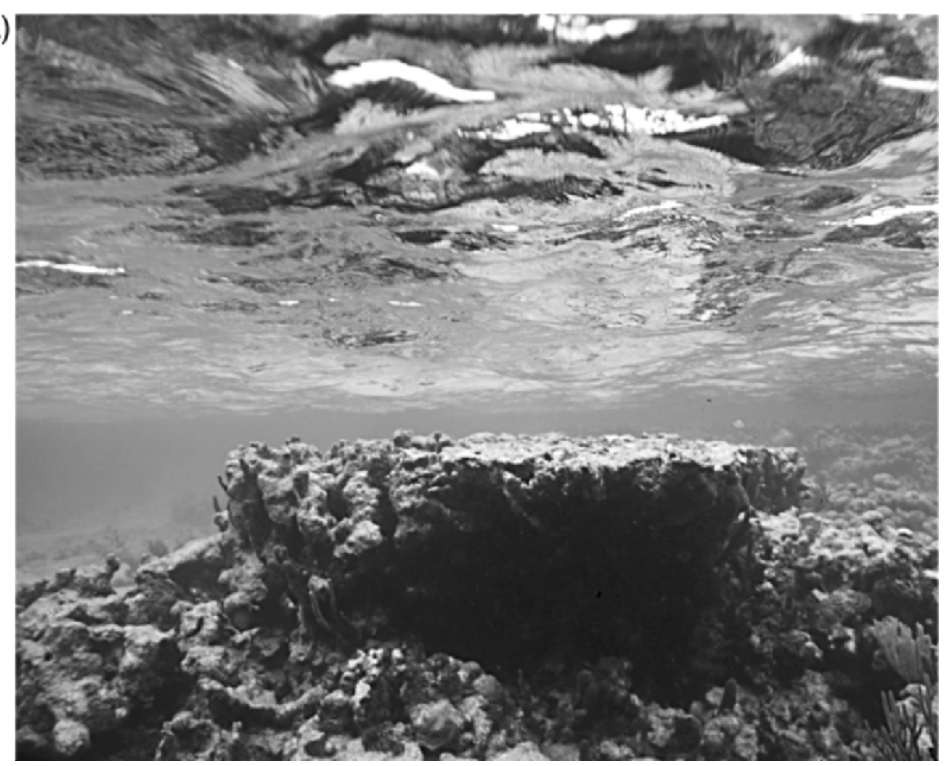

\section{(B)}

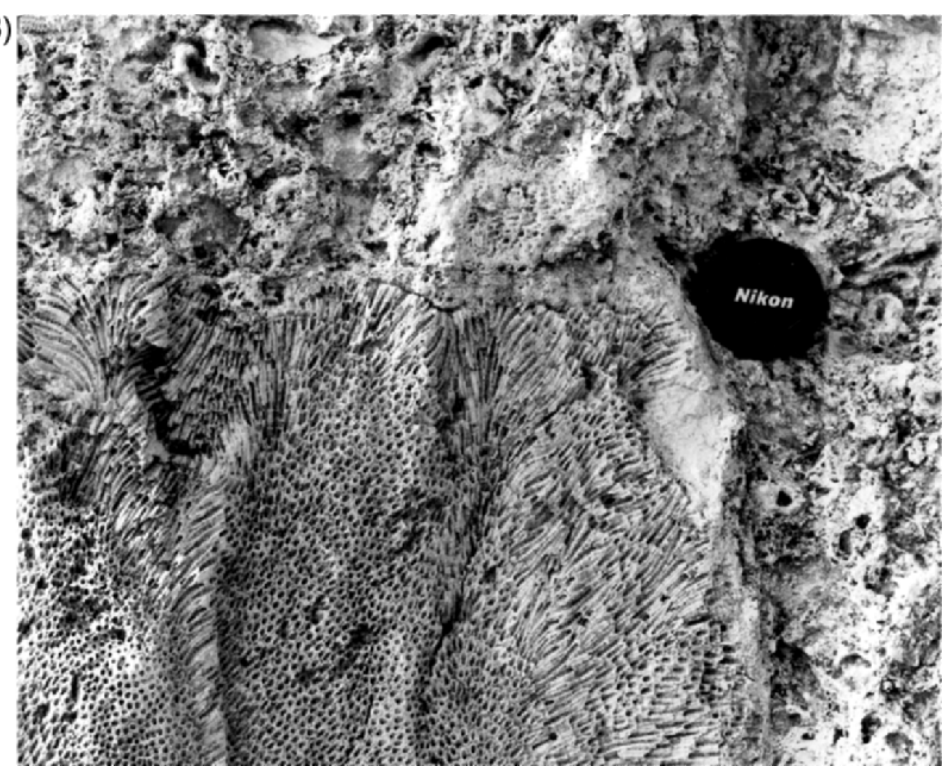

Figure 9.4. (A) Montastraea annularis colony in the Dry Tortugas. Coral is flat-topped in response to growth up to level of spring low tide. (B) Outcrop photograph of flat-topped M. annularis colony in growth position in Windley Key Quarry (Pleistocene, Florida Keys). 
(C)

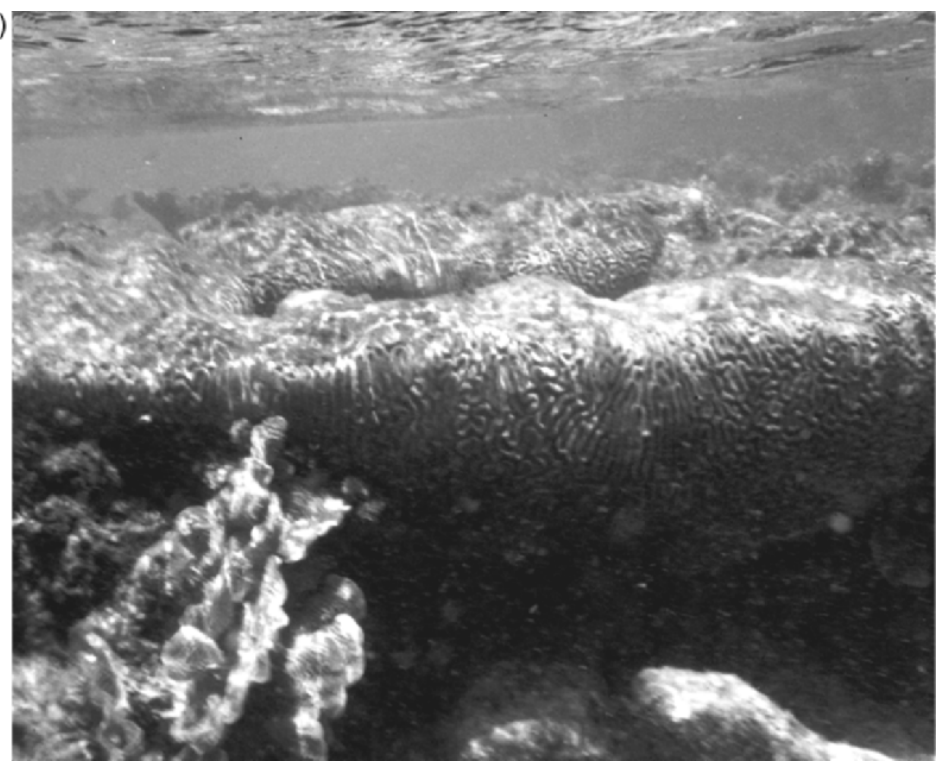

(D)

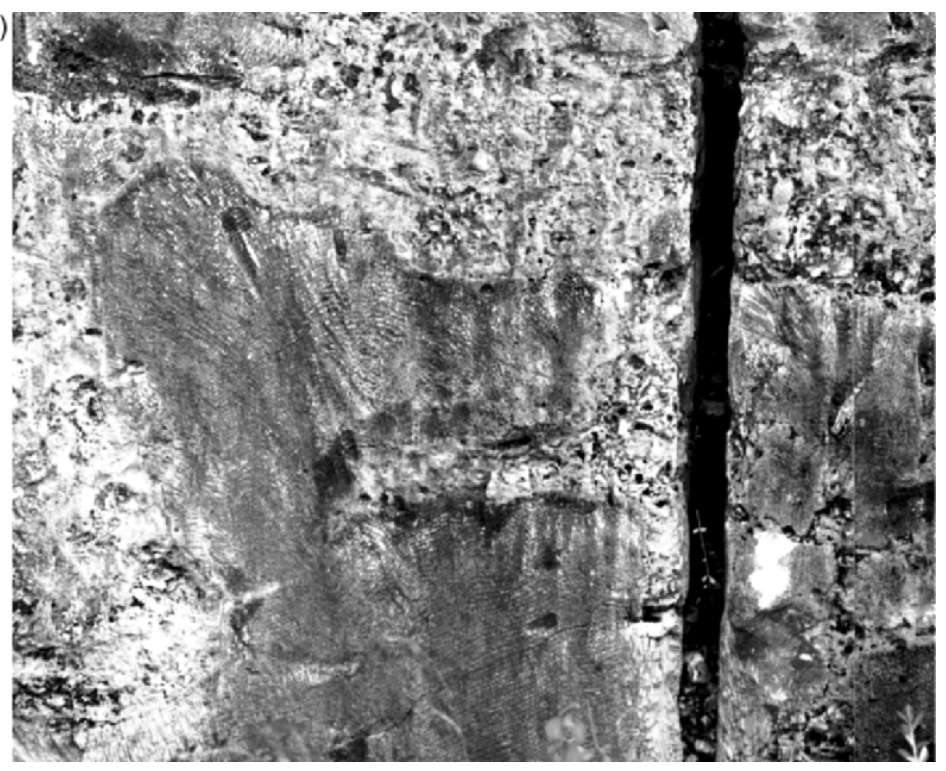

Figure 9.4. (continued) (C) Micro-atoll of living Diploria strigosa colony. This growth form is an excellent marker for spring low-tide levels. (D) Outcrop photograph of microatoll structure in $M$. annularis as a response of coral growth up to sea level, Windley Key Quarry. These paired photographs show the utility of the comparative approach in paleoecologic investigations. 
This was the first time that A. palmata had ever been reported in the Pleistocene Key Largo Limestone, and at the time it suggested that an outer reef existed in approximately the same geographic position as the modern reef tract (Hoffmeister 1974; Multer and Hoffmeister 1977), some $7 \mathrm{~km}$ east of the exposed Pleistocene deposits of the Keys.

Although the hypothesis initially appears reasonable, the stratigraphic relationship between a shallow-water reef community with $A$. palmata at approximately $-17 \mathrm{~m}$ and a known time-equivalent sea level of $+7 \mathrm{~m}$ requires either active tectonic tilting of the platform and/or substantial erosion $(\sim 24 \mathrm{~m})$ of the entire seaward platform margin. Hoffmeister and Multer (1968) preferred the latter interpretation although they indicated, "[T]here is a strong possibility that this was aided by a certain amount of down-tilting or faulting or both." However, the south Florida platform has been tectonically stable during the late Quaternary (Davis, Hine, and Shinn 1992; Lidz, Reich, and Shinn 2003), and although possible, erosion of up to $24 \mathrm{~m}$ of limestone in $120 \mathrm{ky}$ is not likely. Actual erosion rates can be calculated by taking the difference between the maximum sea level at Key Largo time $(+7 \mathrm{~m})$ and the current preserved elevations of the exposed Key Largo Limestone (+1-6 m) throughout the Keys. Subtraction reveals no more than a few meters of loss in the last 120 kyr. Interestingly, Halley and Evans (1983) calculated the amount of surface dissolution to be around $2.64 \mathrm{~m}$ for the stratigraphically and mineralogically equivalent Miami Limestone during the same interval of subaerial exposure. In addition, the occurrence of $A$. palmata living at paleo-water depths in excess of $20 \mathrm{~m}$ cannot be reconciled with the known shallow-depth distribution and absolute water-depth limits of this species (Lighty, Macintyre, and Stuckenrath 1982).

Most important for testing the hypothesis are recently obtained dates of the Pleistocene A. palmata from the core samples. Dating revealed a Holocene age of $2.3 \mathrm{ka}$ (see Multer et al. 2002a), falsifying this early hypothesis. Additional Pleistocene core samples obtained and dated by Multer et al. (2002a) lying directly beneath the Holocene reef tract are not time-equivalent with the exposed limestones of the Florida Keys. Instead, they are part of younger Pleistocene MIS 5c and 5a outlier reefs of Lidz et al. (1991; Fig. 9.5), and these are discussed in more detail later in this chapter.

Using the hypothesis of Hoffmeister and Multer (1968) and Hoffmeister (1974), several subsequent researchers have reached similar conclusions about environmental conditions during development of the Key Largo fossil assemblage. Greenstein and Pandolfi (1997; see also Greenstein, Pandolfi, and Curran 1998) compared life and death assemblages of coral taxa found on living patch reefs and the offshore reef tract with fossil coral assemblages of the Key Largo Limestone. They determined, based on the paucity of acroporids, that the living composition of modern patch reefs was statistically more similar to that of the Key Largo Limestone than to that of the modern offshore reef tract. This similarity led them to conclude that the Key Largo Limestone must have been a series of low-energy patch reefs, supporting the original interpretation of Hoffmeister and Multer (1968). Sixty percent of their modern patch-reef death assemblage, however, was formed by the two major acroporid species, including A. palmata 


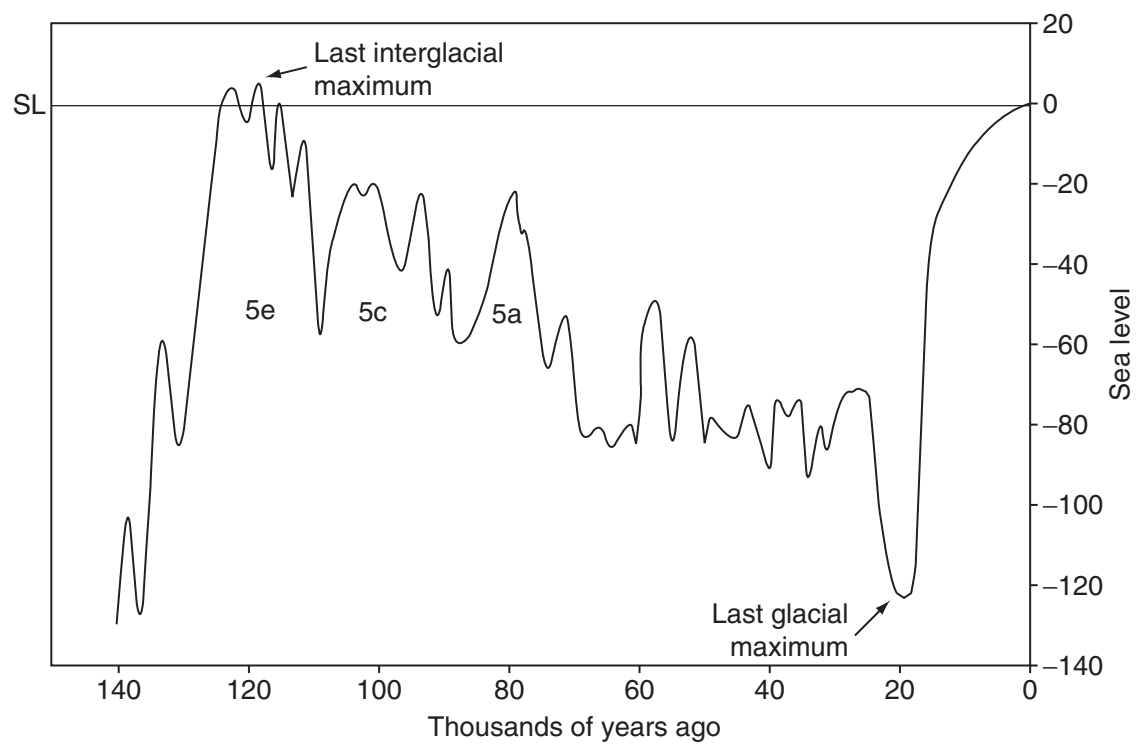

Figure 9.5. Generalized sea-level curve for the last $140 \mathrm{ky}$. Episodes of reef growth occurred during times of sea-level maximum. Marine Isotope Stages of the major highstands are labeled. Data are from numerous sources, including Chappell (1983), Chappell and Shackleton (1986), and Buddemeier and Kinzie (1998). SL, modern sea level.

(Greenstein and Pandolfi 1997). We agree with Greenstein and Pandolfi that although branching corals are probably overrepresented in the death assemblage, it is a reasonable proxy for the fossil assemblage that will result eventually (see also Kissling 1977a). Pandolfi (2002) concluded that there is a high degree of fidelity between the original coral life assemblages and both their adjacent death assemblages and their fossil counterparts in the Caribbean (see also Kidwell 2001). Greenstein and Pandolfi (1997) specifically highlighted the fact that life assemblages examined in the patch-reef environment were dominated by $M$. annularis and $P$. astreoides, whereas the death assemblage was dominated by A. cervicornis. It should be noted that their surveys were performed well after the excision of the acroporids from these reefs as discussed earlier. Their result of abundant Acropora spp. (including the presence of A. palmata) in the modern patch reef death assemblage should therefore not be surprising as Gilmore and Hall (1976) indicated populations of A. cervicornis on patch reefs of the upper Keys, while Shinn et al. (1989) noted that several large patch reefs contained significant populations of A. palmata on their seaward sides before their demise of the past two decades.

If the death assemblages of modern patch reefs of Florida are the appropriate analogues for the fossil record, as postulated by Greenstein and Pandolfi (1997; see also Greenstein and Curran 1997), what happened to all the Acropora in the Key Largo Limestone? An explanation to support this hypothesis would be the 
taphonomic diminution of the acroporids in the transition from the death assemblage to the fossilized reef. However, based on widespread preservation of the acroporids throughout the Caribbean in fossil reefs of the same age and in similar environments, the patch reef model of Greenstein and Pandolfi (1997) is not tenable.

Hodges (1977) supported the low-energy origin for the Key Largo Limestone based on the orientation of head corals in Pleistocene outcrop, where measurements revealed that upright in-place colonies dominate. Recently, Meyer et al. (2003) also concluded that because of high hurricane frequency in the Florida Keys, these in-place colonies are a consequence of their protected setting behind the shelfmargin reef tract. Geister (1980) explained that the almost exclusive occurrence of M. annularis in the Key Largo Limestone indicates protected conditions or a growth depth below normal wave base. It has been shown, however, that corals of the $M$. annularis species complex are extremely robust and resistant to the effects of storms, including hurricanes (Stoddart 1963; Woodley et al. 1981; Graus, Macintyre, and Herchenroder 1984; Woodley 1992; Bythell, Hillis-Starr, and Rogers 2000; Jackson and Johnson 2000), and that their distribution and zonation are due to a combination of factors including, but not limited to, competitive interactions with other corals-notably the Acropora species (Porter et al. 1981; Rylaarsdam 1983; Tunnicliffe 1983; Huston 1985; Aronson and Precht 2001b). In fact, large, centuries-old colonies of the $M$. annularis species complex appear to be the most resistant corals to catastrophic hurricanes in the Caribbean (Stoddart 1963; Woodley 1992; Aronson and Precht 2001b). Upright Montastraea colonies, therefore, do not necessarily indicate conditions of low wave energy.

Graus and Macintyre (1989) demonstrated that the M. annularis species complex occurs at a minimum depth of $1 \mathrm{~m}$ in fore-reef environments in the absence of Acropora. Adey and Burke (1977) also showed that on some reef flats of the eastern Caribbean, colonies of M. annularis, P. astreoides, and Diploria spp. often become as abundant as A. palmata. In Barbados, Montastraea spp. have replaced A. palmata in the shallow fore reef (Lewis 1984). Hunter and Jones (1996) found coral associations dominated by M. annularis, Diploria spp., and Siderastrea spp. in both patch-reef and reef-tract facies of the Pleistocene Ironshore Formation of Grand Cayman. They distinguished between habitats on the presence/absence of rare corals such as Meandrina meandrites, with Meandrina generally being absent from lagoonal patch reefs. Meandrina colonies are an integral part of the coral fauna of the Key Largo Limestone leading again to the interpretation of a reeftract setting for the Key Largo fossil assemblage.

Also important in eliminating Hypothesis 2 is the occurrence of M. annularis in reef-crest positions from locations along the Florida reef tract. Vaughan (1919b) identified M. annularis as the predominant coral species in the shallow Tortugas reef community (Fig. 9.6). Also, Shinn et al. (1977), citing modern examples from the Florida Keys, noted that in areas of low A. palmata abundance or absence, head corals predominate in the reef-crest facies. Specifically, they stated, "[T]he reefs at Marker $G$ and those at Dry Tortugas have the same coral fauna as the Key Largo formation, but the lack of A. palmata shows that it is no longer necessary 


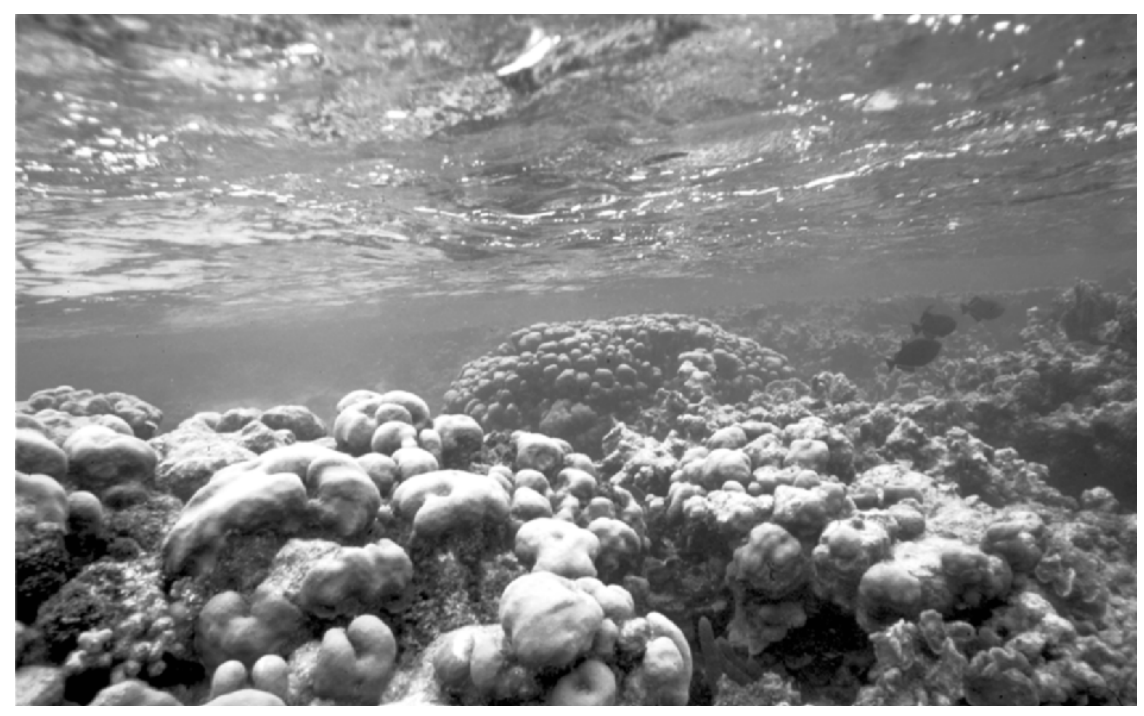

Figure 9.6. High-energy, reef-crest community dominated by monospecific stands of massive M. annularis. Photo is from the Dry Tortugas. This modern-day coral assemblage is an excellent counterpart to the fossil reef exposures of the Pleistocene Key Largo Limestone.

to call on a patch reef origin. Reefs can form and keep pace with sea level at the platform margin, for reasons not (yet) understood, without the help of A. palmata."

Hypothesis 3: Dodd, Hattin, and Liebe (1973) proposed a modification of the Hoffmeister and Multer (1968) patch-reef hypothesis for the exposed Key Largo Limestone. They speculated that the linear nature of the exposed Key Largo Limestone reef system is analogous to an elongate series of modern patch reefs dominated by head corals forming on a bathymetric high on the lagoon floor near Big Pine Key. Antecedent control can explain the linear nature of these reefs, but the rationale used above to falsify the patch-reef origin of Hypothesis 2 is the same here.

Hypothesis 4: Perkins (1977) proposed an explanation based on an analogy with the modern shelf-margin sand-shoal complex, White Bank, and associated inner-shelf patch reefs. The present-day White Bank is a continuous sand shoal that is $40 \mathrm{~km}$ long and 1 to $2 \mathrm{~km}$ wide. White Bank is actively migrating in a landward direction due primarily to transport by storms (Ball, Shinn, and Stockman 1967; Enos 1977). Adjacent, patch reefs are often engulfed by these migrating sands. Perkins (1977) proposed that similar sand shoals and patch reefs migrated landward during Pleistocene (Q5) sea-level rise on a carbonate ramp and did not require a seaward reef barrier for its inception. At sea-level maximum, the leading shallowest edge of the transgressive unit was preserved as an arcuate patch-reef and skeletal-sand complex. 
Perkins could not reconcile the absence of A. palmata in the Pleistocene without calling on a patch-reef origin. He commented that the modern patch-reef assemblages on the inner shelf were mostly devoid of A. palmata and were more in accord with those of the exposed Q5 coralline facies. Although Perkins' assertion that a hypothetical reef barrier seaward of the present-day Keys did not exist was recently borne out by detailed subsurface investigations (Multer et al. 2002a), we can eliminate the patch-reef origin of Perkins using the same rationale discussed above for Hypothesis 2. Moreover, biotic constituent analysis of sediment types from White Bank has little resemblance to the sediments preserved in the exposed Key Largo Limestone (Stanley 1966; Enos 1977).

Hypothesis 5: Multer et al. (2002a) recently proposed that the exposed MIS 5e reefs of the Key Largo Limestone were shallow-water patch reefs that developed on an antecedent bathymetric high (the Northern Keys High). Based on core and outcrop investigations, they identified well-developed patch reefs with grainstones and packstones forming on the highest elevations of the underlying older Key Largo units. Multer et al. (2002a, p. 254) specifically noted, "In the upper Keys, Q5e patch reefs, grainstones and packstones became well developed on the highest elevations of the Northern Keys High. Some can be seen today exposed in the Windley Key Fossil Reef State Park (formally called the Windley Key Quarry) and along the Key Largo Cross Canal.” Multer et al. (2002a,b) argued that the steeply seaward-dipping geometry of this unit and the absence of an Atlantic breakwater dominated by A. palmata supports the contention that the seaward edge of the MIS 5e platform had a ramp-type character.

Reconstruction of the entire south Florida platform during MIS 5e reveals that the reefs of the upper and middle Keys separate a broad, flat, shallow carbonate platform dominated by back-reef mudstones and skeletal packstones rich in bryozoans to the west (Perkins 1977), from a gently seaward-dipping, coral studded platform to the east (Figs. 9.7 and 9.8). The location of the Upper Keys High thus formed the locus of an arcuate shelf-break between fore- and back-reef environments at the peak of the last interglacial maximum, negating a ramp-type setting proposed by Multer et al. (2002a,b); see Ahr (1973). The Northern Keys High controlled the position of the reef-crest community at this shelf edge and was inherited from underlying older (Q3 and Q4) Pleistocene reefal limestones (Harrison and Coniglio 1985). This reef-on-reef stratigraphic sequence indicates that subsequent episodes of reef development magnified the underpinnings of the Northern Keys High. Hence, this shelf edge reveals that the exposed reefs of MIS 5e were the breakwater reefs of the Florida platform, contrary to the "patch-reefs developed on a carbonate ramp" interpretation of Multer et al. (2002a,b).

Hypothesis 6: This brings us to the final hypothesis of Shinn et al. (1977), Harrison and Coniglio (1985), and others. Understanding what we do about the role of inimical bank waters, the susceptibility and vitality of the acroporids, and the multihabit distribution of $M$. annularis, we can now reconstruct the reef community and associated environments that formed during the higher sea level of the last major interglacial episode. 


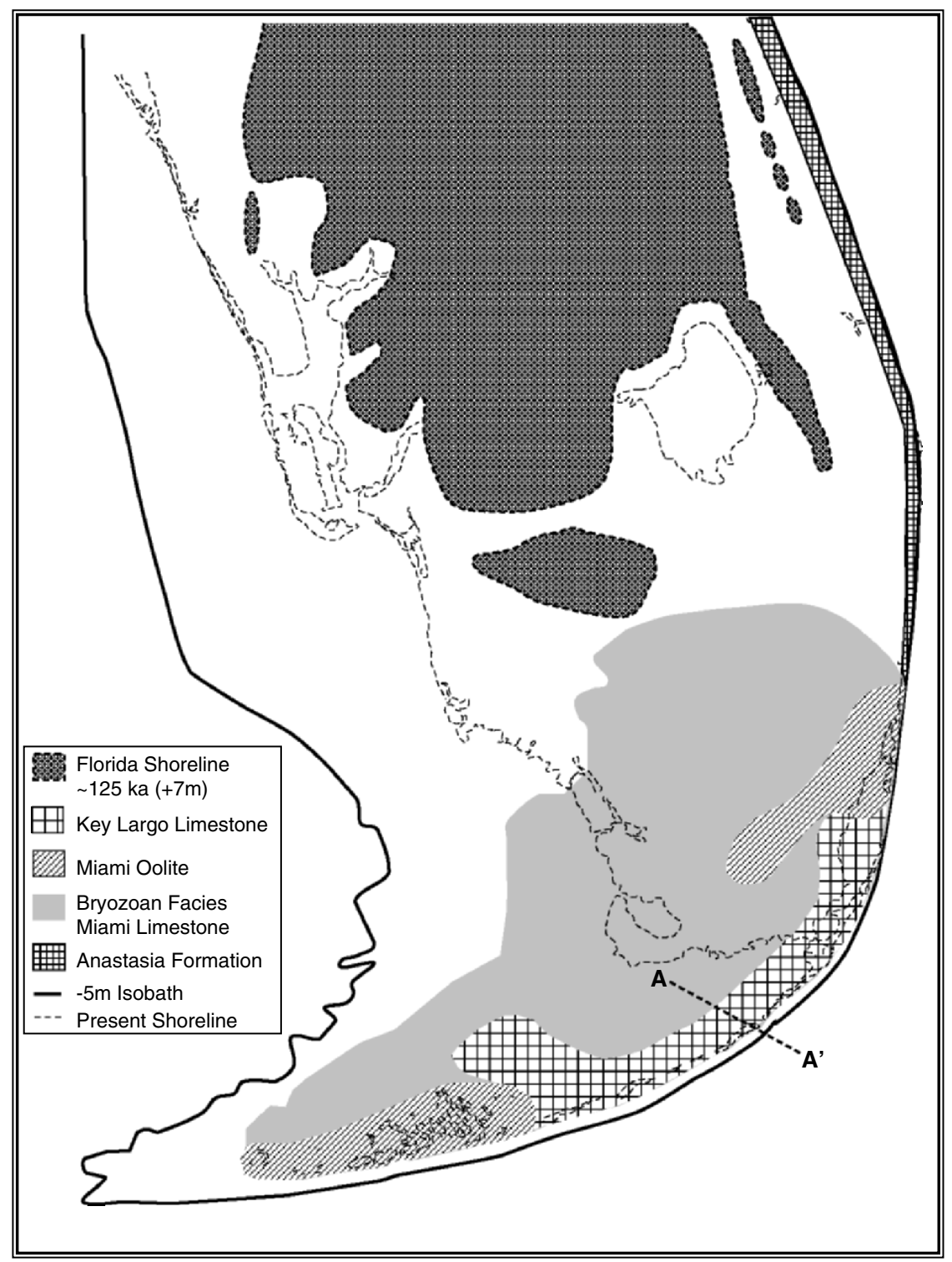

Figure 9.7. Paleogeographic reconstruction of the Florida Peninsula at $\sim 125$ ka during Marine Isotope Stage 5e, when sea level was $\sim 7 \mathrm{~m}$ higher than today. Modified from numerous sources, including Perkins (1977), Harrison and Coniglio (1985), and Multer et al. (2002a). Note the location of stratigraphic cross section (A-A') shown in Fig. 9.8. 


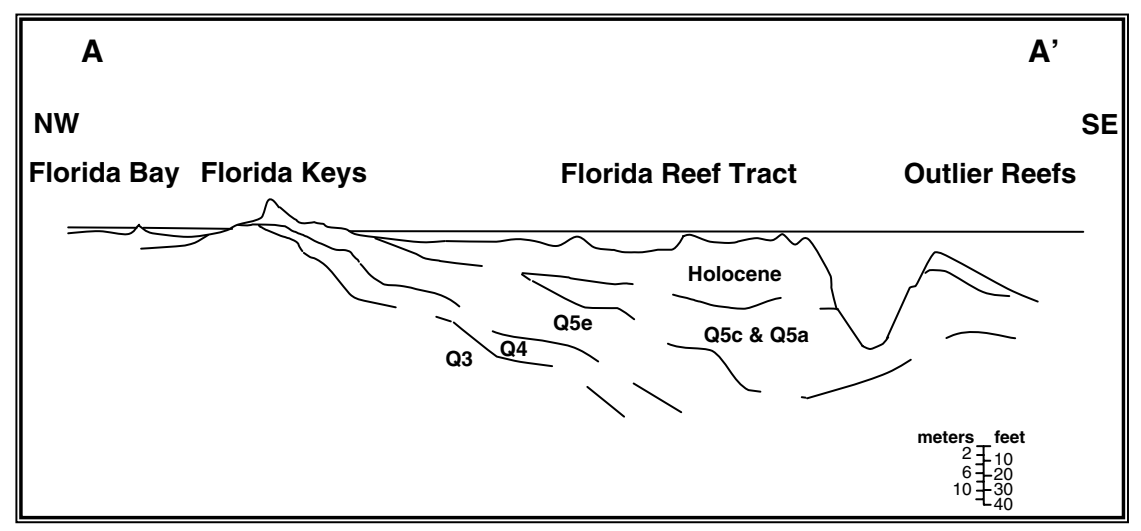

Figure 9.8. Stratigraphic cross section (A- $\left.\mathrm{A}^{\prime}\right)$ across the Florida Keys and reef tract. Stratigraphic units follow terminology of Perkins (1977) and Multer et al. (2002a). Modified from numerous sources including Perkins (1977), Harrison and Coniglio (1985), Lidz et al. (1997a), Lidz (2000a), and Multer et al. (2002a).

Based on time-space relationships in paleoecology and basic ecological principles we would expect that fossil abundance would be greatest near the center of the geographic range of the species in question and progressively decrease to the margin, as optimal conditions graded to less favorable ones (Brown 1984). Because coral reefs of south Florida are at the latitudinal extreme of reef development in the western Atlantic, the absence of A. palmata in the Key Largo Limestone is not surprising, due to contraction and expansion of species ranges in response to changing environmental conditions through time and space. At the apex of the last major interglacial, the entire south Florida Peninsula was flooded, creating a broad, shallow Bahamas Bank-type carbonate platform (Fig. 9.7). This would have allowed unimpeded flow from a much-enlarged Gulf of Mexico over a broad, shallow carbonate bank in the west to the Straits of Florida and open Atlantic in the east. Reef communities forming at the interface between the two would have been bathed by clear, warm, oceanic waters from the Gulf Stream on incoming tides and waters of variable quality, especially in regard to temperature, salinity, and sediment on outgoing tides. With no exposed islands (Keys) to protect the reefs, during the winter months, chilled and sediment-laden bank waters would have periodically poured onto these shelf-margin reefs. Under this scenario the resulting coral community would have been devoid of the shallow, thermophilic reef-crest species A. palmata (Harrison and Coniglio 1985; Shinn 1988). At slightly deeper depths on the fore reef, ephemeral coppices of A. cervicornis would have filled in sheltered pockets in a Montastraea-Diploria-Porites head-coral assemblage.

One line of circumstantial evidence supporting the inimical-conditions model for the Key Largo Limestone comes from the measured growth rates of M. annularis in the fossil record compared to their living counterparts. Hudson (1981a,b) showed that under optimum conditions, the modern growth rate of $M$. annularis along the modern Florida reef tract is $\sim 10 \mathrm{~mm} \mathrm{year}^{-1}$, whereas in the Key Largo 
Limestone it is half that (Hoffmeister and Multer 1964; Shinn et al. 1989). Landon (1975) noted a similar relationship for the extension rates of all forms of the M. annularis complex, Siderastrea siderea, and Porites porites. These reduced growth rates most probably indicate fluctuating and hostile environmental conditions that were unfavorable to all but the hardiest reef-building species during the last major interglacial in Florida.

Stratigraphically, the reconstruction of the exposed Q5 unit of the Key Largo Limestone is straightforward, with the arcuate reef margin of the MontastraeaDiploria-Porites community forming in the position of the present-day islands of the Florida Keys. The location of the exposed Pleistocene reef tract is controlled by the underlying Q3 reefal unit (Perkins 1977; Harrison and Coniglio 1985; Multer et al. 2002a). The sediment accommodation space is filled to its maximum at the point of the shallowest reef community on this topographic feature, forming a series of discontinuous, shallow, bank-barrier type reefs stretching for almost $170 \mathrm{~km}$ (Fig. 9.7). This interpretation requires fewer assumptions about complex geologic processes; specifically tectonic movement, tilting, or large-scale erosion of the platform are not necessary to explain the geography, topography, and species composition of the Key Largo Limestone. Of greatest significance, it does not require A. palmata to have been extant in these high-energy, shallow-water reef communities.

Accepting Hypothesis 6 leads to an interesting question: What would otherwise-healthy Caribbean reefs look like in the absence of the acroporids? To address this question, we have to understand why, under optimum conditions, the acroporids are competitively superior in the first place. In the case of A. palmata, extremely rapid growth and asexual propagation favor the buildup of dense stands in shallow water that are resistant to all but the most extreme storms. These dense coral forests grow above and ultimately shade out most other corals, including the slower-growing M. annularis species complex (Jackson 1991). At intermediate depths, the more fragile, branching A. cervicornis has similar traits, enabling the species to overwhelm other corals and form monospecific thickets (Tunnicliffe 1983). If the acroporids were excised from the reef, subordinate understory corals, including the $M$. annularis species complex and others, would be released from spatial competition. Those remaining species would then respond based on their individual ecologies, with some becoming the new spatial dominants.

Using Hypothesis 6 as our model for the Key Largo Limestone, we can predict the future direction of the reef communities in Florida under a scenario of declining importance of Acropora spp. Originally, the coral community would be dominated by early successional brooding species, especially Agaricia spp. and Porites spp. (Hughes 1985, 1994; Kojis and Quinn 1994; Aronson and Precht 2001c; Edmunds and Carpenter 2001; Knowlton 2001; Cho and Woodley 2002). Many of these brooding species (e.g., $P$. astreoides), however, are relatively short-lived (Kissling 1977b; Hughes 1985). Because of their longevity and their ability to build large, massive, wave-resistant colonies, over time (probably centuries) the M. annularis species complex would become the spatial dominants in this depth range (see discussion of Edmunds and Bruno (1996) in Aronson and Precht 2001b; see also Hughes and Tanner 2000). 
Testing this prediction in real time requires a modern example of a shallowwater, relatively high-energy Caribbean/western Atlantic reef that is, and always has been, totally devoid of Acropora species. The rim and main terrace reefs (2-15 m depth) of Bermuda as described by Logan (1988) fit these requirements. The Bermudian coral fauna is depauperate compared to the rest of the Caribbean-West Indian biogeographic province, with low winter water temperatures invoked as the main cause. These rim/terrace communities are dominated by a Diploria-Montastraea-Porites assemblage and have high coral cover (Dodge, Logan, and Antonius 1982; Logan 1988; Smith et al. 2002). Growth, form, composition, percent cover, and spatial orientation of corals from these Bermudian reefs are in many respects similar to those observed in the Key Largo Limestone (Thaddeus Murdoch personal communication).

\subsubsection{The Late Pleistocene: Marine Isotope Stages 5c, 5b, and 5a}

Toscano and Lundberg (1998, 1999)—see also Lidz et al. (1991), Ludwig et al. (1996), Lidz et al. (1997b), Multer et al. (2002a), Lidz, Reich, and Shinn (2003) - have shown that the reefs that lie beneath the Holocene and modern reef tract are equivalent to MIS 5c and 5a, and they have been dated at approximately 106 to $112 \mathrm{ka}$ and 78 to $86 \mathrm{ka}$, respectively. Recently, Lidz (2004) documented MIS $5 \mathrm{~b}$ reefal deposits dating between 87 and 94 ka sandwiched between the MIS $5 \mathrm{c}$ and $5 \mathrm{a}$ outlier reefs. These outlier-reef deposits exhibit a shelf-margin, wedge geometry, onlapping the seaward-dipping MIS 5e surface (Fig. 9.8), and they form the antecedent underpinning for Holocene reef development in the Florida Keys (Multer et al. 2002a; Lidz, Reich, and Shinn 2003). At the time of the MIS 5a high stand, sea level stood $\sim 9 \mathrm{~m}$ below the present. Paleogeographic reconstruction of the MIS 5a Florida Peninsula reveals a broad, exposed, low-relief plateau with reef development confined to the seaward edge of the platform. This fossil reef subcrops along the entire length of the Florida Keys (Lidz, Reich, and Shinn 2003).

The younger MIS 5c, 5b, and 5a reef tracts had the advantage of being sheltered from deleterious bank waters by the emergent Florida platform. These protected shelf-margin reefs were probably responsible for the reappearance of A. palmata on the Florida reef tract in the late Pleistocene. Evaluation of the stratigraphic position and subsea elevation of the MIS 5c and 5a reefal units by Toscano and Lundberg (1998) also confirms the tectonic stability of the Florida platform throughout the late Quaternary.

\subsubsection{The Latest Pleistocene and Holocene History of Reef-Building}

The last glacial maximum (LGM) occurred during the Pleistocene Epoch about $18 \mathrm{ka}$. At that time, global sea level was $\sim 120 \mathrm{~m}$ lower than today (Matthews 1986; Fairbanks 1989; Bloom 1994). CLIMAP (1976) hindcast models indicated that minimum sea-surface temperatures during this time were less than $2{ }^{\circ} \mathrm{C}$ cooler than those associated with modern Caribbean seas. Since then debate has arisen 
as to whether tropical SSTs may have been as much as 4 to $5{ }^{\circ} \mathrm{C}$ colder during this period (Guilderson, Fairbanks, and Rubenstone 1994; Beck et al. 1997). However, recent data and global climate models estimate a drop of no more than $\sim 2.5^{\circ} \mathrm{C}$ (Crowley 2000). Trend-Staid and Prell (2002) found only a 1.0 to $1.5^{\circ} \mathrm{C}$ drop at the LGM in samples from near Barbados. The data, coupled with other data from all ocean basins, led them to the conclusion that SSTs in the western tropics and subtropics were essentially indistinguishable from modern values. This suggests that temperature was not low enough to terminate reef development through the last major glacial-interglacial cycle. The coral faunas that comprised the reef-building episodes of the previous interglacial high stands show amazing similarity in species composition throughout the Pleistocene and Holocene, so we can speculate that these corals and reef communities persisted in downslope refugia during the glacial low sea stands.

Pandolfi (1999) speculated that the major drop in sea level at the LGM resulted in a dramatic loss of habitat, causing the rapid extinction of some widespread Caribbean coral species. The fact that Indo-Pacific corals did not experience similar extinctions under essentially the same sea-level and temperature history argues against these as being the primary causal agents (Budd, Johnson, and Stemann 1994). This is also contrary to evidence from Pleistocene molluscan assemblages which reveal species responding to sea level and climate change by fluid geographic shifts rather than by extinction or speciation (Roy et al. 1996). Thus, quantitative habitat loss associated with geological-scale processes seems an unlikely extinction mechanism, especially in light of the fact that Kleypas (1997) calculated that during the LGM coral reef growth was more extensive than previously thought. Paulay (1990) indicated that reef geomorphology was an important control in the distribution of bivalve species through glacialinterglacial cycles. He noted that although inner-reef lagoons are stranded during glacial low stands, resulting in extirpation of soft-bottom bivalve fauna, coraldominated fore-reef environments persisted, albeit displaced downslope. As the continental shelves were flooded at 8 to $10 \mathrm{ka}$ the total area available for reef growth increased. Goreau (1969) used the phrase "post-Pleistocene urban renewal of coral reefs" to describe the Holocene reemergence of reefs associated with the flooding of platforms during the last deglaciation.

SSTs in the subtropical western Atlantic show a warming between 14 and $10 \mathrm{ka}$, a maximum that is warmer than today between 10 and $6 \mathrm{ka}$, and a late-Holocene cooling to modern values (Balsam 1981; Ruddiman and Mix 1991; Bradley 2000). Evidence from coring submerged reefs off Barbados (Fairbanks 1989) shows a backstepping of A. palmata communities that essentially track postglacial sea level from 17.1 to $7.8 \mathrm{ka}$. Sea-level curves derived from dates of A. palmata allow for the calculation of the rate of glacial meltwater discharge into the Atlantic (Fairbanks 1990). Rates of rise of sea level were rapid during this period, punctuated by two periods of extremely rapid rise (meltwater pulses) in the latest Pleistocene. During these rapid bursts, sea-level rise apparently outstripped the accumulation rates of A palmata, leading to brief hiatuses of reef growth (i.e., incipient drowning), followed by a backstepping of the shallow-reef communities 
to more shoreward positions higher on the shelves. In south Florida, such drowned shelf features have been identified using high-resolution seismic, side-scan sonar and in situ sampling by submersibles in water depths of 50 to $124 \mathrm{~m}$ (Locker et al. 1996). Although the rate of rise in sea level during the Holocene (the last $10 \mathrm{ky}$ ) has never exceeded the maximum accretion rate of $A$. palmata, reef growth was not continuous but punctuated by a series of reef ridges and troughs (Lighty 1977; Lighty, Macintyre, and Stuckenrath 1978; Lidz and Shinn 1991; Toscano and Lundberg 1998; Precht et al. 2000; Lidz, Reich, and Shinn 2003).

In some areas, numerous distinct relict reef ridges are present (Lighty, Macintyre, and Stuckenrath 1978) while in other areas there is a gradational separation (Toscano and Macintyre 2003). These relict Holocene reefs, comprised primarily of A. palmata, are found at water depths between 20 and $7 \mathrm{~m}$ south of Miami and between 27 and $7.8 \mathrm{~m}$ depth to the north (Toscano and Lundberg 1998; Toscano and Macintyre 2000). In all, very few reefs have been sampled and dated, making it difficult to evaluate the precise chronology of the turn-on and turn-off of this reef system.

Throughout most of the early to middle Holocene, however, oceanic conditions were favorable for the growth and accumulation of A. palmata along much of the Florida reef tract. In fact, major Acropora-dominated reefs were well-developed off Palm Beach County (Lighty 1977; Lighty, Macintyre, and Stuckenrath 1978), indicating that water quality along the platform margin was more favorable to coral growth than today. A buried topographic feature lying off Fort Pierce may be the northernmost extent of this mid-Holocene reef tract (Hine 1997).

We interpret this northward range expansion of the Acropora spp. as a reflection of northward excursions of warm water related to a unique conjunction of factors. First, during this time lower sea level placed the active shelf-margin reef system in closer proximity to the equable waters of the Gulf Stream. Second, the period from about 9 to 5 ka corresponds to the mid-Holocene Warm (Zubakov and Borzenkova 1990; Pielou 1991; Maul 1992; Thompson et al. 1998; Zhou, Baoyin, and PetitMarie 1998; Kerwin et al. 1999). Terrestrial records indicate that the climate in North America was 2 to $4{ }^{\circ} \mathrm{C}$ warmer than at present during this interval (Folland, Karl, and Vinnikov 1990). Climate simulations suggest that North Atlantic SSTs were at least $4{ }^{\circ} \mathrm{C}$ warmer than today at $6 \mathrm{ka}$ (Kerwin et al. 1999). Stable oxygenisotopic values recorded in sediments from the extratropical North Atlantic also indicate warmer-than-present SSTs during the mid-Holocene (Ruddiman and Mix 1991). Evidence from both terrestrial and coastal regions shows that warming during this interval allowed many organisms to increase their ranges northward (Clarke et al. 1967; COHMAP 1988; Delcourt and Delcourt 1991; Pielou 1991; Salvigsen, Forman, and Miller 1992; Dyke, Dale, and McNelly 1996; Strasser 1999; Dahlgren, Weinberg, and Halanych 2000; Jackson and Overpeck 2000). This period of thermal optimum during the Holocene also correlates with the northernmost position and expansion of coral reefs in the Pacific (Taira 1979; Veron 1992). Warmer conditions apparently allowed the northward expansion of acroporid-dominated reefs throughout southeast Florida (Precht and Aronson 2004). As temperatures have cooled since the middle Holocene ( $5 \mathrm{ka}$ to present), 
the conditions for acroporid reef growth have diminished and the northward limit of the reef tract has progressively moved south to its present position. While reefs at their latitudinal extremes have responded rapidly to climate flickers, results from coring studies of Holocene reefs in the insular tropical Caribbean support the notion that tropical oceanic climates have been buffered from climatic variability (Gill, Hubbard, and Dickson 1999).

Dead and senescent Holocene reefs are also present throughout the middle Florida Keys (Lidz, Robbin, and Shinn 1985; Shinn et al. 1989; Shinn, Lidz, and Harris 1994; Lidz and Hallock 2000). Geologic investigation of these reefs has shown that the acroporids were again the major constructors and frame builders until the late Holocene. Reconstruction of these shallow shelf-margin reefs in relation to sea-level rise by Lidz and Shinn (1991) showed that the flooding of Florida Bay around 2 to $3 \mathrm{ka}$ was contemporaneous with the localized demise of A. palmata on many of these reefs. Specifically, Lidz, Reich and Shinn (2003) commented that this flooding led to deteriorating water quality by tidal and storm-driven mixing of bay and Gulf waters, causing the coral reef system to decline. Shinn et al. (1981) indicated that the deep-reef spurs (15-20 m) at Looe Key initiated around $6.5 \mathrm{ka}$, with the shallow-reef spurs developing $\sim 4 \mathrm{ka}$ and ceasing $~ 800$ years ago. In the lee of large islands, however, some reefs maintained active growth and were dominated by the acroporids until the combined events of the last few decades led to their decline. Such reefs can have Holocene deposits >14 m thick (e.g., Grecian Rocks and Key Largo Dry Rocks).

These spatial examples of reefs with differing geologic histories confirm the inimical-waters model of Ginsburg and Shinn $(1964,1994)$. They also attest to the fact that conditions favorable to expansive reef growth have been diminishing on the Florida platform for the past few millennia.

\subsection{The Present Status of the Florida Reef Tract}

All of the classic environmental issues faced by coastal communities and coral reefs worldwide (Wilkinson 2002) are concentrated in the narrow strip of land that is the Florida Keys. These issues include development, ship groundings, pollution, and overharvesting. Regional and global perturbations that affect coral reefs, such as coral bleaching and coral disease, are also present in Florida. The decline of living reefs in Florida was first reported by Voss (1973) and was a concern in the Florida Keys as early as the 1950s. Indeed, the perceived degradation of coral reefs from overfishing, coastal development, and increasing visitation in Key Largo were the main reasons for the creation of the world's first coral reef marine protected area, John Pennekamp Coral Reef State Park, in 1960 (Voss 1960). Although various forms of reef protection in Florida have been around since the 1960s, most of these have been set ad hoc and without programs in place to assess their efficacy. Recently a systematic, ecosystembased management approach has been implemented to protect Florida's reefs (NOAA 2003). 
We are aware of only one quantitative reef-monitoring program from the early 1970s for the lower Florida Keys (Kissling 1977a). This study integrated hydrological, sedimentological, and ecological elements of nine reef areas located from Looe Key to Sand Key. Kissling's data indicated diverse living coral assemblages, with death assemblages dominated by fragments of Acropora spp. Subsequent monitoring studies by Dustan (1977), Dustan and Halas (1987), Jaap, Halas, and Muller (1988), and Porter and Meier (1992) all documented examples of coral decline but only from single sites or at limited spatial scales. Extrapolating these results to the entire Florida reef tract is problematic due to variability at scales larger than those of individual reefs (Murdoch and Aronson 1999). Further, these studies focused on the emergent reef systems in the Keys that represent a habitat type that comprises a small fraction of total area in the region. Additional onetime assessments without temporal follow-ups include work in the early 1980s in John Pennekamp Coral Reef State Park and the Key Largo Coral Reef Marine Sanctuary (Voss 2002), Biscayne National Park (Burns 1985) and Looe Key (Wheaton and Jaap 1988); in 1995 throughout the Keys (Murdoch and Aronson 1999); and in 1996 for 20 reef sites in the upper Keys (Chiappone and Sullivan 1997). At Looe Key, landscape-scale reef censuses were performed in 1983 and 2000 (Miller, Bourque, and Bohnsack 2002).

The US Environmental Protection Agency (EPA) in conjunction with the Florida Marine Research Institute (FMRI) and NOAA started the first Keys-wide status-and-trends program in 1996 (Jaap et al. 2001). This program documented coral cover during the period 1996 to 2000 (and continues to the present), with estimated declines as high as $36 \%$ and averaging about $6 \%$ to $10 \%$ across 40 stations sampled in multiple coral reef habitats. Although it was spatially extensive, the program began long after substantial coral loss had already occurred, particularly the demise of the branching corals A. palmata and A. cervicornis. Of the 40 stations in the study, only seven contained A. palmata in 1996. At these seven sites, the average loss of A. palmata was 85\% between 1996 and 1999 (Patterson et al. 2002). At first blush these results are alarming; however, they need to be placed in perspective. The average percent cover of A. palmata at the seven sites was around $\sim 5 \%$ in 1996 and had declined to $2 \%$ by 1999, which is an absolute change in coral cover of only $3 \%$. One of the stations sampled included the reef at Rock Key. There, A. palmata cover dropped from $<4 \%$ to slightly less than $2 \%$. This is the same reef that Enos (1977) described as having no living A. palmata in the early 1970s.

It could well be that these small populations of A. palmata represent residual, transient, or marginal populations that are highly susceptible to both biotic and physical disturbances including disease, predation, storms, cold fronts, and coral bleaching events. Interestingly, the period 1996 to 2000 of the Jaap and Patterson studies spanned two major coral bleaching events in 1997 to 1998, continued outbreaks of pests and disease, and the passage of a major hurricane directly over many of the sampling stations. At this writing, there has not been a coral-bleaching event in Florida since 1998, and recently published data from the EPA study show a leveling off of coral decline after that last regional disturbance (Wilkinson 2004). 
The EPA program and two other Keys-wide sampling programs (Murdoch and Aronson 1999; Miller, Swanson, and Chiappone 2002) are important because they documented patterns of community structure, and underlying processes that drive community structure can sometimes be inferred from patterns that emerge across multiple spatial scales (Cale, Henebry, and Yeakley 1989; Aronson 1994, 2001; Done 1999). The EPA results focused on change over time (Jaap et al. 2001), but understanding change across spatial scales is also important. For example, across deeper reef sites (13-19 m) in the Keys, spatial variability was found to be greater between adjacent reefs than across geographic regions (Murdoch and Aronson 1999). Assessments of marine protected areas across the Florida Keys, which were originally selected to capture much of the shallow spur-and-groove habitat in the FKNMS, revealed that these reefs are as likely to be different from each other as they are from surrounding reference sites or those subjected to fishing (Miller, Swanson, and Chiappone 2002). Both studies suggest that processes operating at multiple spatial scales determine coral community structure. Furthermore, these results are important from a management perspective because it is easier and more cost-effective to manage a system if one knows the constraints of overall system variability and history instead of trying to achieve results that are outside the bounds of the system (Allen and Hoeskstra 1992; Jameson, Tupper, and Ridley 2002). This premise will be discussed in more detail below.

The longest historical record available for the Florida reef tract is derived from maps of community distributions in the Dry Tortugas, meticulously prepared by Alexander Agassiz in 1881 and then redrawn from new surveys in 1976 (Agassiz 1883; Davis 1982). A number of interesting changes in coral community structure occurred over that century, all of which could be attributed to natural system variability. For example, the spatial extent of octocoral-dominated communities increased from $\sim 5$ to $17 \%$. Thousands of square meters of $A$. palmata were alive in 1881, but they were largely reduced to alga-covered rubble by the late 1970s, with only two living patches $\left(\sim 600 \mathrm{~m}^{2}\right)$ in 1976. A. cervicornis cover was not common in the late 1880s, according to Agassiz's map; it dominated many locations by 1976 (Davis 1982), only to suffer $>90 \%$ morality during the winter cold fronts of 1977 described earlier. These results suggest a dynamic system in the Dry Tortugas, just west of the Florida Keys, outside the bounds of direct human influences such as coastal development.

One peculiar event recorded in the reefs of the Dry Tortugas occurred in 1878 and was referred to as "black water" (Mayer 1902; see also Davis 1982). This event purportedly eliminated almost all the A. cervicornis from the Dry Tortugas, yet historical records show some recovery of the affected populations only a few years later (Agassiz 1883). In 2002 a large mass of black water originally of unknown origin was spotted off the southwest coast of Florida. Preliminary results indicate that a bloom of diatoms commingled with a "red tide" were the main constituents of the black water (South-West Florida Dark-Water Observations Group 2002). This water mass moved toward the Dry Tortugas and lower Florida Keys, with some reports of mortality to sponges and corals (Hu et al. 2003). 
Ongoing investigations and surveys will hopefully shed some light on this enigmatic condition and, in retrospect, on the event of 1878.

Evaluating the present state of Florida Keys reefs and predicting their future requires that managers and scientists integrate historical information with an understanding of the agents that drive community change at multiple spatial and temporal scales in the present. In practice, managers address these challenges at local scales and over careers that are shorter than many of the underlying ecological processes that affect the way coral reefs look and function. From a societal perspective, working for short-term gains is the easiest and often most politically expedient course of action, but the recent regional and global declines in coral reefs over the last two decades require bold and unconventional approaches (Buddemeier 2001). The following sections describe factors that affect the present state of reefs in Florida. We will use this information to make predictions about the future trajectory of these reefs in ecologic and geologic time.

Such discussions typically follow a standard approach by listing and distinguishing natural from human-caused stresses to reefs. We will instead identify what we believe to be the principal threats caused by humans and then dismiss most of them as not relevant to the long-term condition of reefs in the Florida Keys. For example, physical impacts such as damage by divers or snorkelers and individual dredge-and-fill projects are clearly important as factors that cause damage locally (Taylor and Saloman 1968) but generally do not have systemwide effects on the condition of reefs. Similarly, harvesting of live rock (coral rubble with living coelobites, endoliths, and epibionts) may have been important historically when live rock was routinely extracted from reefs in the Florida Keys, but such activity is now prohibited. Furthermore, it is well documented that marine collectors extract large numbers of ornamental species, but this reduction is not thought to impact longterm reef condition or growth. Vessel groundings are among the most destructive anthropogenic factors causing significant localized damage to Florida's reefs; however, detailed management strategies addressing these insults have been evaluated and are now being implemented (Precht 2006). Introduction of exotic species is a potential problem (Stachowicz et al. 2002) but is not currently viewed as a factor affecting reef condition. It is possible that many marine diseases are invasive species but this linkage has not been established. We do not mean to imply that these factors are unimportant to the condition of the Florida reef tract. Indeed, it is precisely the fact that these and other impacts were important at the scale of individual reefs along the Florida Keys that caused them to be managed and protected in the first place (Jaap 1994; Davidson 2002; NOAA 2003).

\subsubsection{Water Quality}

The most publicized environmental issue related to the demise of coral reefs is declining water quality. The reason water quality is so often cited as the cause of coral reef decline in the Keys is that the increased abundance of algae observed on reefs over the last two decades supports an intuitive assumption that nutrient enrichment must be the cause (Szmant 2002). Those who advocate nutrient 
pollution as the primary factor behind coral reef decline in the Keys have proposed connections from agricultural runoff in the Lake Okeechobee region, through the Everglades, into Florida Bay, and ultimately to the offshore coral reefs of the Keys (Brand 2002; Lapointe, Matzie, and Barile 2002). Although the Everglades system is eutrophic in its northern reaches, including the Lake Okeechobee watershed, path analysis of nutrient concentrations reveals an extremely oligotrophic system to the south, through Everglades National Park and into Florida Bay (Stober et al. 2001). If agricultural nutrients do not impact the southern reaches of Everglades National Park and Florida Bay, or do so minimally, then it is even less likely that effects will be seen on the offshore reefs. At an even larger scale, it has been suggested that the entire Caribbean basin may be enriched due to its semienclosed geography and increased runoff from poor land-use practices, coastal development, and deforestation (Muller-Karger et al. 1989; Hallock, Muller-Karger, and Halas 1993). Regionally, large volumes of Mississippi River water have been found embedded in the Florida Current from Key West to Miami, confirming large-scale connectivity (Lee et al. 2002), and this water may have an influence on reef growth and development (Ogden et al. 1994).

In addition to supposed linkages with agricultural runoff from the Everglades, sewage pollution from local sources is often emphasized as the cause of ecosystem decline in the Florida Keys (Lapointe, O'Connell, and Garrett 1990). What, then, explains the unambiguous increases in algae that are seen Caribbean-wide? Recent reviews of the role of nutrient enrichment on coral reef decline (Szmant 2002) and the relationships among nutrients, algae, and competition between algae and corals (McCook 2001; McCook, Jompa, and Diaz-Pulido 2001) suggest that the increased abundance of algae is not due to nutrients but instead is explained by the availability of new substrate for algal colonization following coral mortality (Aronson and Precht 2001b; Williams, Polunin, and Hendrick 2001; McManus and Polsenberg 2004). The role of herbivores is clearly also a factor in explaining increased algal abundance on reefs in Florida, from the demise of D. antillarum throughout the Caribbean (Lessios 1988), to observations that an inverse relationship exists between algae and herbivorous fish biomass surveyed on 19 reefs throughout the Caribbean (Williams and Polunin 2001). Distinctions are typically not made between benthic habitats nearshore (especially hardbottom communities and seagrass beds close to shore) and the main reef tract located 5 to $7 \mathrm{~km}$ offshore. While few data exist to suggest that changes in offshore reef communities were caused by local pollution sources in Florida, and although few historical data exist regarding nutrient pollution, algal abundance, or coral cover (Szmant 2002), strenuous debate about the relative importance of topdown (Hughes et al. 1999; Miller et al. 1999; Aronson and Precht 2000) versus bottom-up (Lapointe 1997, 1999) processes continues (see Davidson 1998).

The water-quality debate is additionally fueled in Florida by reports of increased nutrient concentrations (Lapointe, O'Connell, and Garrett 1990), the presence of viral tracers (Paul et al. 1995) and fecal indicator bacteria (Paul et al. 1997) that are detectable in nearshore waters and corals (Lipp et al. 2002), but 
other studies have not found increased nutrients or these microbial constituents in offshore waters or sediments (Szmant and Forrester 1996), seagrass beds (Fourqurean and Zieman 2002), or algae (Hanisak and Siemon 1999). A threeyear study of nearshore waters (Keller and Itkin 2002) throughout the Keys found that total nitrogen and phosphorus concentrations did not differ significantly between developed and undeveloped shorelines, although variability was high. Boyer and Jones (2002) revealed that ambient water quality along the Florida Keys and throughout the FKNMS was most strongly influenced by natural oceanographic parameters. While they noted that differences in various waterquality parameters were significantly different across many of their 150 stations, the absolute differences were small and not likely to be biologically important.

Sewage disposal via septic tanks and cesspits represents a pollution threat to canals and nearshore waters due to the highly porous Key Largo Formation, upon which the Keys have been developed. Rates of contaminated groundwater flow to nearshore waters have been measured from injection wells and septic systems (Lapointe and Clark 1992; Shinn, Reese, and Reich 1994; Paul et al. 1995). Factors that influence groundwater flow include the difference in water level between Florida Bay and the Atlantic Ocean, daily tidal cycles, and meteorology (Reich et al. 2002; but see Shinn, Reich, and Hickey 2002). Additional evidence for reduced water quality stems from patterns of groundwater discharge detected using chemical tracers (Corbett et al. 1999) and the presence of over 20,000 septic systems, some 2000 remaining cesspits, and approximately 5000 shallow-water injection wells located in porous limestones throughout the Keys (Shinn 1996; Kruczynski and McManus 2002). Influences related to storm-water runoff are also sources of pollution (Lapointe and Matzie 1996; Brad Rosov personal communication). Hudson et al. (1994) contended that domestic sewage from the Miami area has been a major factor in reducing coral growth rates in the upper Keys since the 1950s. However, Ginsburg, Gischler, and Kiene (2001) demonstrated that corals from these upper Keys reefs had less dead tissue per colony than those on reefs in the middle and lower Keys.

Chiappone (1996) and Miller, Chiappone, and Swanson (unpublished data) found that along a gradient from onshore to offshore, coral cover was highest and algal cover lowest on nearshore patch reefs with a switch to algal dominance as one moves to reefs offshore throughout the FKNMS. This is contrary to the results one would expect if land-based sources of nutrients and pollutants were responsible. Miller, Weil, and Szmant (2000) found similar relationships in both coral cover and coral recruitment on reefs of the northern Keys.

Risk et al. (2001) indicated that it is possible to discern natural versus anthropogenic nutrients (especially sewage) using geochemical techniques. Ward-Paige, Risk, and Sherwood (2005) measured $\delta^{15} \mathrm{~N}$ in gorgonian corals and Lapointe, Barile, and Matzie (2004) measured $\delta^{15} \mathrm{~N}$ in macroalgae, both concluding that anthropogenic nitrogen pollution was responsible for the increased $\delta^{15} \mathrm{~N}$ values they found. However, Swart, Saied, and Lamb (2005) measured $\delta^{15} \mathrm{~N}$ in the scleractinian Montastraea faveolata and did not find any indication of nitrogen pollution. Furthermore, based on extensive sampling and a thorough literature 
review, Swart (personal communication) cautions that for several reasons it is not possible to use specific $\delta^{15} \mathrm{~N}$ values alone as an indicator for sewage, including: (1) variable isotopic signals for sewage that are not always heavy; (2) $\delta^{15} \mathrm{~N}$ results measured for particulate organic material that did not differ along nearshore to offshore transects throughout the Keys; and (3) discovery that the $\delta^{15} \mathrm{~N}$ of particulate organic matter from inshore stations is largely derived from seagrasses and macroalgae, not sewage. Even if sewage pollution makes its way to offshore reefs, the amount supplied must be measured relative to substantial natural nutrient sources due to Gulf Stream flow, tidal flushing (Szmant and Forrester 1996), and upwelling (Leichter, Stewart, and Miller 2003). The Gulf Stream and tidal movements must also be considered a diluting influence relative to potential sewage inputs.

One of the largest quantified sources of episodic nutrient additions to offshore reefs in the Keys is frequent cold-water upwelling events that deliver high concentrations of nitrate and phosphate on a regular basis (Lapointe and Smith 1987; Leichter and Miller 1999; Leichter, Stewart, and Miller 2003; Smith et al. 2004; for a similar analysis from the Great Barrier Reef, Australia, see Andrews and Gentien 1982; Sammarco et al. 1999). Leichter, Stewart, and Miller (2003) noted enriched $\delta^{15} \mathrm{~N}$ at depth related to internal tidal bores. More recently, Leichter (personal communication) measured the $\delta^{15} \mathrm{~N}$ values of the upwelled nitrate in these waters and found them to be sufficiently high to confound interpretations that sewage or runoff is responsible for increased $\delta^{15} \mathrm{~N}$ measured in seaweed collected along the outer reef tract (Lapointe, Barile, and Matzie 2004). These upwelling events deliver water with 10 - to 40 -fold higher nutrient concentrations than published estimates of inputs to nearshore waters from wastewater and stormwater. Based on the physical oceanographic processes responsible for the transport and delivery of these high-concentration nutrient pulses, it is likely that the offshore reefs of the Florida reef tract have historically and periodically been subjected to high concentrations of nonanthropogenic nitrate and phosphate. Periodic advection of coastal waters may also deliver pulses of nutrient-rich water to the offshore reefs (Pitts 2002).

Szmant $(1997,2002)$ suggested that the level of topographic complexity on a reef indirectly influences the effects of nutrient input and uptake. In the absence of overfishing or mass mortalities of herbivores, topographic complexity determines the availability of shelter for herbivores. The recent mass mortality of the acroporids has greatly reduced the topographic complexity of these reefs, reducing herbivore populations and thereby reducing rates of algal consumption in the face of pulsed or chronic nutrification (Szmant 1997). For coral reef and seagrass habitats, however, it has been shown that intact herbivore populations can compensate for effects of increased nutrient supply by locating and consuming nutrientenriched algae (Boyer et al. 2004). While the necessary modeling has not been conducted to quantify the relationships among various nutrient sources and sinks in the Keys, blaming sewage from leaking cesspits or runoff from the Everglades Agricultural Area as the primary causes of coral-reef decline in Florida is almost certainly an oversimplification. 
Water quality, however, explains some important things about the Florida reef tract. For instance, in the last few thousand years, reef development has been greater seaward of the Keys than seaward of the tidal passes between them. As previously discussed, this inimical-waters model explains the discontinuous nature of reefs along the reef tract. One would therefore expect a similar effect today with coral assemblages being healthier and more robust where the Keys block the flow from Florida Bay. This, in fact, is not what is happening, as essentially all reef communities of the Keys - even those blocked from Florida Bay-are in decline (Murdoch and Aronson 1999). It may well be that all reef areas of the Keys, not just those seaward of the tidal passes, are being exposed to poor-quality water. However, water quality along the Florida reef tract is best seaward of Key Largo (Boyer personal communication); yet coral loss has historically been highest in this area. This is exactly opposite of Lapointe's hypothesis for local nutrient sources as the proximal cause of reef decline in the Keys. It is becoming increasingly apparent that regional- and global-scale causes of reef decline are most important in structuring modern reef communities including those in Florida.

Gardner et al. (2003) used meta-analysis to assess the extent of coral decline across the Caribbean since the 1970s. Their results revealed that reefs from all regions were affected. Interestingly, Florida's reefs showed lower levels of loss than other regions. In general, the same maladies affecting coral reefs in Florida are present throughout the Caribbean, with reefs both near and far from anthropogenic sources of nutrients displaying similar community shifts from coral to macroalgal domination (Aronson and Precht 2001c). For instance, Lapointe, Littler, and Littler (1997) used reefs of the offshore barrier reef tract of Belize in the vicinity of Carrie Bow Cay as an example of a low-nutrient (oligotrophic) reef system and as a counterpoint to the Florida reef tract (Lapointe 1997). Like Florida, these Belizean reefs have recorded significantly reduced coral populations, especially the acroporids, with concomitant increases in macroalgae over the past two decades in the absence of nutrient enrichment (Rützler and Macintyre 1982; Littler et al. 1987; Aronson et al. 1994; McClanahan and Muthiga 1998; McClanahan et al. 1999; Aronson and Precht 2001b; Precht and Aronson 2002). Likewise, McClanahan et al. (2003) showed through experimental manipulation that coral mortality combined with low herbivory is responsible for the high levels of macroalgae reported on remote patch reefs at Glovers Reef Atoll, Belize. In another manipulative field experiment off Key Largo, Miller et al. (1999) found strong effects on increasing frondose macroalgal biomass as a response to exclusion of large herbivorous fishes and only negligible effects from nutrient enrichment.

To determine if there were linkages between deteriorating water quality and reef condition in the Florida Keys, Dustan (1994) performed coral vitality studies off Key Largo. He used reefs from San Salvador Island in the easternmost Bahamas as his "unaltered" control. Nutrient-depleted, oligotrophic pelagic waters bathe these Bahamian reefs and local anthropogenic impacts were deemed minimal. Interestingly, there was no statistical difference in diseased and degraded corals 
between the Bahamian reefs and the reefs in the Florida Keys. The Bahamian reefs had suffered the same catastrophic losses of acroporid corals in the early 1980s related to the Caribbean pandemic of WBD (Shinn 1989; Aronson and Precht 2001b). More recently, a coral-bleaching event recorded in 1995 at San Salvador resulted in a significant decline of the remaining coral species, with concomitant increases in macroalgae. This community shift occurred without changes in herbivore abundance or nutrient concentrations (Ostrander et al. 2000).

Bryant et al. (1998) profiled the Florida Keys reefs as one of the world's twelve most threatened. However, they stated, "[D]espite years of research, it is difficult to lay blame for damage on specific anthropogenic stresses." Association between nearshore nutrient enrichment and coral mortality followed by a shift toward macroalgal dominance does not by itself prove a causal connection. In fact, evidence linking anthropogenic nutrients to coral reef decline in Florida remains correlative. The most important consequences of increased nutrification may, however, lie in an increase in the severity and duration of coral diseases (Bruno et al. 2004) and in the inability of coral reefs to recover from disturbance events, especially if human activities serve to increase the frequency and/or intensity of the disturbance regime (McCook, Wolanski, and Spagnol 2001).

Lastly, Kinsey (1991), Smith and Buddemeier (1992), and Buddemeier and Kinzie (1998) have pointed out that elevated nutrient levels are commonly regarded as intrinsically damaging to the physiological function of corals. Nevertheless, corals often grow well at high nutrient levels (Atkinson, Carlson, and Crow 1995; Szmant 1997). Furthermore, corals can persist in close juxtaposition to macroalgae that are commonly regarded as superior competitors in high-nutrient situations (see de Ruyter van Steveninck, Van Mulekon, and Breenan 1988; Miller 1998; McCook 2001; Jompa and McCook 2002). Clearly the role of nutrients on coral reefs is not completely understood.

\subsubsection{Climate Change}

On coral reefs, most predictions of the effects of global climate change have been confined to temperature-induced coral bleaching (Hoegh-Guldberg 1999; Walther et al. 2002), rising sea level (Graus and Macintyre 1998), and changing ocean chemistry (Kleypas, Buddemeier, and Gattuso 2001; Buddemeier, Kleypas, and Aronson 2004). Recent reports have also identified the poleward expansion of reef corals as a response to climatic warming (Precht and Aronson 2004). The effects of climate change are most likely to be seen in community and species responses to the changes in the nature, intensity, and/or frequency of extreme events.

In the last two decades, documented coral bleaching events have increased in frequency and intensity both globally and regionally (Hoegh-Guldberg 1999). Evidence from sclerochronological studies supports the suggestion that widespread coral bleaching is a recent phenomenon (Halley and Hudson, Chapter 6). Stone et al. (1999) proposed that the sudden occurrence of mass bleaching episodes is coincident with intensification of El Niño-Southern Oscillation (ENSO) events, which may be augmented by global warming (Hoegh-Guldberg 1999; Aronson et al. 2002b; Hughes et al. 2003). 
In Florida, bleaching events occurred during 1983, 1987, 1989, 1990, 1991, 1997, and 1998 (Causey 2001). Mortality after the 1983 bleaching event, affecting only the outer reefs in the lower Keys, was estimated at 3 to 5\% (Causey 2001). The first major Keys-wide bleaching event occurred in 1987, with recovery of most of the affected colonies. The worst years on record for coral bleaching were 1997 and 1998, worldwide and in Florida (Causey et al. 2000; Wilkinson 2000). In the Keys, corals remained bleached or mottled from 1997 into 1998, when they experienced another episode of bleaching due to excessively warm summertime conditions (Edmunds, Gates, and Gleason 2003). These consecutive bleaching events in Florida caused alarm among local scientists and managers. Declines in coral cover were reported during the 1997 to 1998 period (Jaap et al. 2001), but because high-frequency before-during-and-after sampling was not conducted, the relationship between coral mortality and bleaching remains correlative. Two hurricanes also affected the region during this period, further confounding interpretations. Although estimates of bleaching-related coral mortality are not available for Florida, anecdotal evidence suggests that bleaching has killed large numbers of corals (Causey 2001) and must be considered a significant threat to reefs in Florida (Szmant 2002). The projected continuing increases of bleaching events on Florida's coral reefs related to global warming are likely to decrease coral abundance into the future (Hoegh-Guldberg 1999; Walther et al. 2002; Sheppard 2003). Bleaching was not observed in Florida in 1995, yet major bleaching with associated mortality was observed in Belize (McField 1999) and at San Salvador Island in the Bahamas (Ostrander et al. 2000).

Predicted effects of changes in seawater chemistry on reef growth (carbonate production) are based largely on geochemical evidence and modeling. Essentially all of the experiments that have manipulated seawater carbonate chemistry and measured effects on corals, calcifying algae, and coral reef mesocosms indicate that calcification approaches a linear response to decreased carbonate saturation state (Kleypas, Chapter 12). Based on the factors that control $\mathrm{CaCO}_{3}$ precipitation, it is very likely that dissolution will increase on reefs as atmospheric $\mathrm{CO}_{2}$ concentrations increase, leading to reduced capacity for reef building.

Extreme weather and climate events will likely increase in the future (Easterling et al. 2000), especially in mid- to high-latitude settings. For coral reefs the most profound changes are likely to be seen at the latitudinal extremes of reef building, including the reefs of Florida. Increases in extreme high temperatures, decreases in extreme low temperatures, and increases in tropical storms and hurricanes will likely add stress to a reef system already suffering from numerous natural and anthropogenic perturbations.

\subsubsection{Overfishing}

Overfishing is often considered to be one of the most significant threats to coral reef ecosystems (Roberts 1995; Jackson et al. 2001). At high intensities, fishing reduces species diversity and can lead to extirpations of not only target species, but other species as well. Most importantly, overfishing interacts with other 
disturbances such as disease outbreaks in populations of herbivorous sea urchins, reducing the capacity of reefs to recover from natural perturbations such as hurricanes (Hughes 1994; Nyström, Folke, and Moberg 2000; Knowlton 2001; Bellwood et al. 2004).

In the Florida Keys overfishing of finfish and shellfish has resulted from a combination of commercial pressure and substantial recreational effort (Bohnsack, Harper, and McClellan 1994; Ault, Bohnsack, and Meester 1998; Bohnsack 2003). Substantial declines have occurred in historically productive snapper and grouper fisheries (Ault et al. 2001). Densities of herbivorous fish, however, remain high compared to many sites in the Caribbean, mostly because fishermen do not target these species (Aronson et al. 1994; Bohnsack, Harper, and McClellan 1994). This is especially relevant in Florida because herbivorous fish may have ameliorated the effects of the 1983 to 1984 mass mortality of the sea urchin Diadema antillarum compared to other sites with depauperate herbivorous fish populations, which suffered substantial increases in macroalgal cover and biomass after the urchin dieoff (Hay 1984; Carpenter 1990a,b; Aronson and Precht 2000, 2001b).

One model of coral-reef ecology holds that the persistence of reef communities turns on positive interactions between corals and herbivorous fish (Hay 1981; Hay and Goertemiller 1983; Hay and Taylor 1985; Lewis 1986; Szmant 1997). Several studies have demonstrated the negative effects of fishing on tropical resources (Hughes 1994; Roberts 1995; Rogers and Beets 2001). Results from marine protected areas also suggest that such connections can be important (McClanahan and Muthiga 1988). Equally important, some authors have argued historical declines in the population densities and body sizes of herbivorous and predatory fish have gone unrecognized as potential agents of change in coral reef habitats (Jackson 2001; Jackson et al. 2001).

Pandolfi et al. (2003) argued that the only reasonable explanation for the longterm degradation of reef systems is overfishing. The loss of large predators, including groupers, snappers, and sharks, has likely had substantial cascading effects on the structure of fish assemblages (Aronson 1990; Ault, Bohnsack, and Meester 1998; Pauly et al. 1998; Steneck 1998), which in turn has led to collapse of whole reef ecosystems at the global scale (Pandolfi et al. 2003).

The idea that overfishing has been a main cause of the collapse of coral assemblages on reefs of Florida and the Caribbean has been the subject of contentious debate (Aronson et al. 2003; Precht et al. 2005b) that continues to the present (Precht and Aronson 2006). It is clear that overfishing can eliminate entire functional groups and lead to trophic cascades on reefs (Pauly et al. 1998), but there is no evidence that reef decline in Florida or elsewhere in the Caribbean have been compromised by these actions.

Coral reef ecosystems throughout the Caribbean and western Atlantic including Florida have been overfished for decades and perhaps centuries (see Wing and Wing 2001). It may well be that reefs with their full complement of trophic levels and resources will be more resilient to disturbances than those that are overexploited (Knowlton 2001), but it remains premature to assume that coral assemblages will automatically recover to historic levels if fish populations are restored. 
Effective management strategies such as the creation of marine reserves should help restore and protect fishery resources, possibly resulting in increased reef resilience. In the FKNMS, the recent establishment of some 23 no-take marine reserves is a first step.

\subsubsection{Diseases}

Major disease events in recent years have changed the way reefs look over relatively short time scales. For example, in the early 1980s a disease epidemic killed almost all the $D$. antillarum that once thrived in the Caribbean region (Lessios, Robertson, and Cubit 1984), including the Florida Keys (Forcucci 1994). D. antillarum was an important grazer, and after the mass mortality substantial and longterm increases in macroalgal populations generally resulted, especially on reefs subjected to intense fishing pressure (Hay 1984; Carpenter 1990a,b; Hughes 1994).

Urchin recovery has begun at a few locations in the Caribbean (Aronson and Precht 2000; Edmunds and Carpenter 2001; Cho and Woodley 2002) but not in the Florida Keys, where a second dieoff was observed in the early 1990s (Forcucci 1994). A recent Keys-wide survey counted few urchins but discovered evidence of significant adult populations in the Dry Tortugas (Chiappone et al. 2001). Although the cause of the urchin dieoff remains unknown (but see Bauer and Agerter 1987), it represents one of two ecologically critical disease outbreaks that swept through the Caribbean and Florida in the last 25 years.

The second epidemic, WBD (discussed previously), still affects acroporid corals in Florida (Precht and Aronson 1997; Porter et al. 2001; Santavy et al. 2001). The loss of the acroporids due to WBD significantly reduced the threedimensional structure of the reefs and effectively eliminated two of the major reef-building corals from the region (Sheppard 1993; Aronson and Precht 2001c; Precht et al. 2002). Coring studies in Belize and Jamaica have revealed that the regional mass mortality of acroporid corals from WBD was novel on a centennial to millennial scale (Aronson et al. 2002a; Wapnick, Precht, and Aronson 2004). The combined effects of the two lethal, essentially concurrent, Caribbean-wide epizootics resulted in what was apparently an unprecedented, regional shift from coral to macroalgal dominance (Knowlton 2001).

Estimates of the prevalence of WBD in remnant A. cervicornis and A. palmata populations in the FKNMS were obtained over the period 1999 to 2001 and were $3.2 \%$ and $5.6 \%$, respectively (Chiappone, Miller, and Swanson 2002). In addition to WBD, another lethal disease known as white pox, which is specific to A. palmata, has been identified throughout the Florida reef tract (Holden 1996). The common bacterium Serratia marcescens has been implicated (Patterson et al. 2002). Because $S$. marcescens can be a human fecal enterobacterium, Patterson et al. (2002) inferred that its pathway into the marine environment is likely via human waste. However, further evidence is needed to substantiate this species as more than an incidental pathogen. Others have noted that $S$. marcescens is commonly found throughout the marine realm, including in the gut tracts of fish (Bruckner 2002). As enterobacteria are ubiquitous in the marine environment, it should not 
be surprising that some should be opportunistic pathogens of fish and marine invertebrates, including corals that are already stressed.

Beginning in the 1970s and continuing through today, coral diseases or disease-like syndromes have appeared in other coral species throughout the Caribbean (Antonius 1977; Edmunds 1991; A. Bruckner, Bruckner, and Williams 1997; Nagelkerken et al. 1997; Santavy et al. 1999; Garzon-Ferreira et al. 2001), Bermuda (Garrett and Ducklow 1975), and the Florida Keys (Dustan and Halas 1987; Kuta and Richardson 1996; Richardson et al. 1998; Porter et al. 2001; Santavy et al. 2001; Patterson et al. 2002). Other environmental stressors such as pollution, increased nutrients, increased iron supply, African dust, and temperature may be associated with coral disease outbreaks, yet no firm connections have been established (Shinn 1996, 2001; Epstein et al. 1998; Hayes and Goreau 1998; Harvell et al. 1999; Hayes et al. 2001; Jackson et al. 2001; Richardson and Aronson 2002; Bruno et al. 2004). Antonius (1977) described a white syndrome in acroporid corals, which he termed shut-down reaction (SDR). He noted that even a slight break in coral tissue in "stressed" colonies triggered SDR. The symptoms of SDR are similar to WBD but highly accelerated. It may be that stress due to increased temperature contributes to white syndromes in the acroporids. The long-term impacts of coral diseases on populations remain difficult to assess, but disease is clearly a major factor in the continued decline of corals and reef function in Florida.

\subsection{The Future}

Future climatic and environmental changes are emerging as major research priorities in the new millennium. The National Research Council (1988) recommended that studies documenting population, community, and ecosystem responses to rapid environmental changes of the Quaternary could provide the necessary insight into the rates and directions of biotic changes in the future. It has been argued that Quaternary reefs from the Caribbean display stability and persistence in coral assemblage structure through time and, therefore, constitute the most important database for the study of modern reefs (Jackson 1991, 1992; Pandolfi and Jackson 1997; Pandolfi 1999, 2002). While we agree that these studies demonstrate predictable patterns of reef community membership in tropical areas during glacial-interglacial cycles, we disagree with the notion that persistent, tropical coral assemblages represent biologically integrated faunas (e.g., Jackson 1994). Rather, persistence was likely due to individual species tracking suitable habitats, favorable environmental conditions, and fluctuating sea levels in time and space (see Brett, Miller, and Baird 1990; Holland 2000).

Much can be learned about coral ecology from Pleistocene reefs of the Caribbean: the persistence of reef zonation schemes through time, the continuity of environments during sea level fluctuations, and the fidelity of community and species composition during successive high stands in the tropics. It may well be, however, that reefs living under suboptimal conditions in more thermally reactive 
areas, including reefs in Florida tell a different story and may be more useful for predictive studies. We believe that had Jackson, Pandolfi, and colleagues looked in the other direction, at the latitudinal extremes of subtropical reef systems, they would have come to a very different conclusion about the stability of reef ecosystems. For instance, the reef community at Rottnest Island off Western Australia $\left(32^{\circ} \mathrm{S}\right)$ has some 25 species of zooxanthellate corals, most occurring at the southern limits of their ranges, with Acropora spp. being rare (Marsh 1992). However, during the last major interglacial (MIS 5e) major reefs were formed by both staghorn and tabular Acropora spp. (Szabo 1979; Playford 1988). In a similar analysis, Veron (1992) showed that on the world's highest-latitude coral reef in Tateyama, Japan $\left(33.5^{\circ} \mathrm{N}\right)$, differences in species composition between the midHolocene and the modern indicate that even a brief period of regional or global warming can produce significant changes in coral assemblages. Conversely, in the insular tropics the mid-Holocene temperature maximum had no effect on species composition or reef-building (Gill, Hubbard, and Dickson 1999).

When conditions have been favorable in Florida, as they were during the middle Holocene, acroporids have dominated the shallow-reef community. When conditions have deteriorated, as in the Pleistocene, head corals have dominated and persisted. Species replacements and range expansions in the past, especially of the Acropora spp., emphasize the resilience of reef ecosystems and the individualistic responses of coral species to rapid environmental change in the absence of major human modification of the seascape.

Recent changes to Florida's coral reefs could persist for decades or longer, and it is unclear how future global climate change will interact with disease and other stresses (Brown 1997; Harvell et al. 1999; Kleypas et al. 1999). The virulence of some coral diseases may be positively correlated with increases in temperature, which could doom reefs in the face of global warming (Rosenberg and Ben-Haim 2002). The combined effects of numerous anthropogenic impacts could alter ecosystem resilience and prevent recovery of the affected reefs (Knowlton 1992; Nyström, Folke, and Moberg 2000; McCook, Wolanski, and Spagnol 2001).

What is required for recovery in the Florida Keys? Of course, the recent demise of the Acropora in the Caribbean has not yet been tied to extinction. In ecological time, the prolific growth of the acroporids (see Shinn 1966, 1976) could essentially repopulate all of the habitats occupied in Florida prior to the WBD epidemic. Populations of Acropora spp. persist throughout their geographic range, including Florida, and substantial recovery could occur on a decadal scale (Woodley 1992; see Idjadi et al. 2006). If the acroporids do recover, we would expect prolific and expansive acroporid thickets in the lee of large islands or seaward of the mainland of the Florida Peninsula, in areas protected from inimical waters.

Recent observations in the Keys show that short-term, sporadic, and spatially limited acroporid thickets can develop from remnant populations. Demise of these reoccurring smaller populations remains highly probable, but in the face of global warming a northward expansion of the acroporids and the reef tract is also possible, mimicking the conditions of the mid-Holocene (Precht and Aronson 2004). The recent occurrence of A. cervicornis thickets off Fort Lauderdale presents an 
interesting case. Are these populations a harbinger of impending global change, or do they merely represent the temporary range expansion of remnant stands, which are likely to be killed by the next cold front or hurricane?

Factors related to biology may limit recovery of the acroporids. Dependence on asexual propagation in the acroporids comes at the expense of larval production (Hughes 1989; Knowlton, Lang, and Keller 1990). A. palmata and A. cervicornis are broadcast spawners, releasing their eggs into the water column for fertilization and development. Because these corals are now rare, they may be experiencing an Allee effect; colonies may be too far apart for high fertilization success (Knowlton 1992). Low levels of sexual recruitment by A. cervicornis have slowed its recovery at most Caribbean localities. Although rapid growth and fragmentation are also strategies employed by A. palmata, this species shows slightly higher rates of sexual recruitment to disturbed areas than A. cervicornis (Highsmith 1982; Rosesmyth 1984; Jordán-Dahlgren 1992). Currently, brooding coral species, which retain their eggs after internal fertilization and release their offspring as planula larvae, are recruiting more successfully than broadcast spawners in the Caribbean (Fig. 9.9). All Caribbean representatives of the families Agariciidae and Poritidae are brooders, and Agaricia agaricites, $P$. astreoides, and $P$. porites are among the first coral species to appear on disturbed reef surfaces, including Acropora rubble fields (Bak and Engel 1979; Rylaarsdam 1983; Rogers et al. 1984; Hughes 1989; Edmunds et al. 1998; Aronson and Precht 2001c; Knowlton 2001).

What else could prevent recovery? Disease pathogens are still present (Santavy et al. 2001; Aronson and Precht 2001c; Patterson et al. 2002), cold-weather fronts still occur, bleaching events are increasing in frequency and intensity, hurricanes

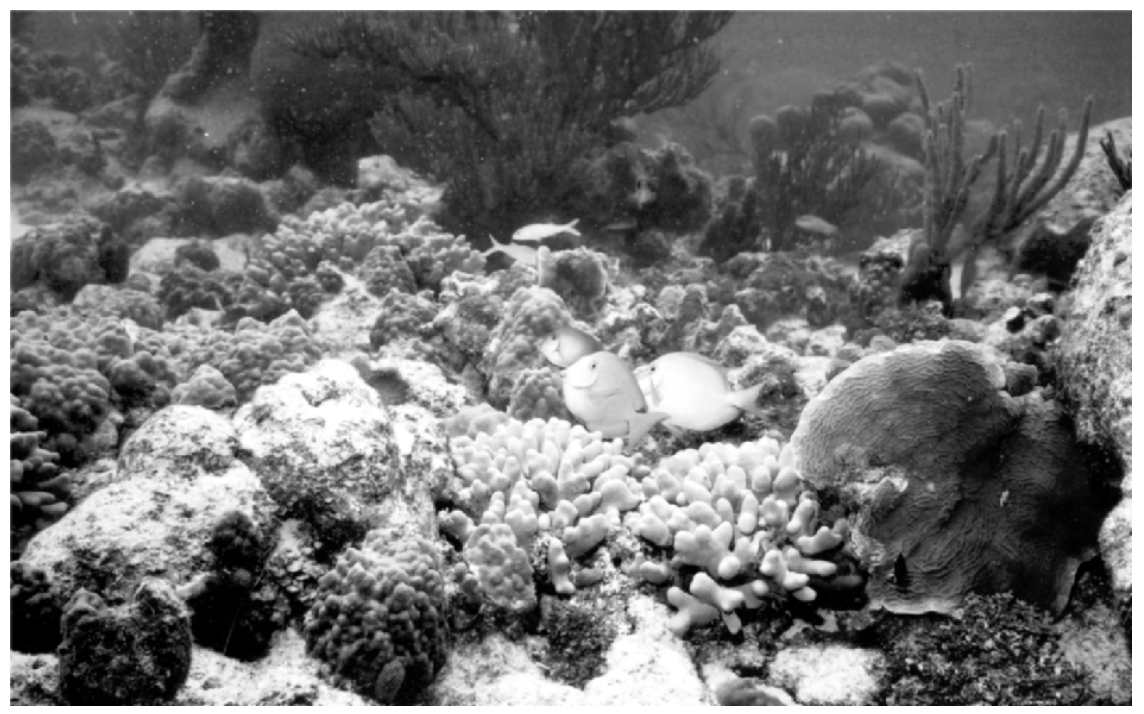

Figure 9.9. Present-day coral assemblage in many shallow fore-reef settings. Brooding species dominate, especially Porites astreoides, P. porites, and Agaricia agaricites (forma danai). 
can set back reef development, and predators are continuing to take their toll on remnant populations (Knowlton, Lang, and Keller 1990; Bruckner, Bruckner, and Williams 1997; Miller 2001), especially when other stressors are also present (Hughes 1989, 1994; Knowlton 1992; Hughes and Connell 1999). Suitable substrate may also limit larval recruitment where algal populations remain high (Hughes and Tanner 2000). If one or both of the Acropora species do not recover, we predict continued high abundance of fleshy macroalgae and an increasing role for weedy, fecund, brooding corals such as Porites and Agaricia. At longer time scales of decades to centuries, we predict that slower-growing, eurytopic, headcoral species, especially the Montastraea species, will prevail.

In retrospect, we are lucky to have reefs in Florida at all. Disease outbreaks; coral bleaching; extreme weather events, including hurricanes and cold fronts; and the average annual position of the Gulf Stream all affect the nature and presence of reefs in Florida. A major challenge to scientists and managers working in the Keys is to understand the combined effects of natural system variability and human-caused damage. Can we use our knowledge of reefs through time in Florida and the rest of the Caribbean to establish guidelines, methods, and strategies for protection and stewardship?

\subsection{Management Implications at the Interface of Geology and Ecology in South Florida}

Wood (1999) stated, “[A]ncient reefs are too often studied solely as geological phenomena with little regard to the detailed biological interactions within their constructional communities." Her premise was that if one does not understand the biology of a reef, one does not understand the reef at all. Conversely, Aronson and Precht (2001b) commented ". . . that paleobiologists pay close attention to ecology, but ecologists largely ignore the fossil record." They noted that if the important questions for the future are to be answered, we must combine the two disciplines as Gould (1981) suggested.

Paleoecological studies of Pleistocene and Holocene reefs: (1) make it possible to investigate ecological processes that occur over temporal scales longer than most long-term (decadal-scale) ecological studies; (2) provide a baseline for the condition of reefs prior to human influence; and (3) enable us to evaluate the response of corals and coral reefs to environmental changes of magnitudes that are beyond historical values but within the range of projected global change. Understanding natural change in reef community structure preserved in fossil sequences can provide a major source of information for predicting future change. Specifically, the lessons learned from paleoecological studies can form the basis for the restoration and management of modern ecosystems (Foster, Schoonmaker, and Pickett 1990). If present approaches to conservation are not sufficient to preserve or restore existing or damaged reef systems (Buddemeier 2001), then can we do anything that will make a difference?

Coral reefs in the Florida Keys that are typically described as the ones in need of salvation represent only a fraction-about $2 \%$ - of the total coral habitat in the 
Florida Keys (FMRI 1998). These are the shallow spur-and-groove locations that until recently were dominated by A. palmata and A. cervicornis, and they are the reefs that kept pace with rising sea level through the Holocene; they are the named reefs on nautical charts (Fig. 9.2). What about the other $98 \%$ of coral habitat in the Keys? There are vast stretches of shallow and deep hard-bottom habitats characterized by low hard-coral cover, variable but often-high algal cover, and variably abundant gorgonians and sponges (Enos 1977; Chiappone and Sullivan 1994). Many of these habitats are probably little changed over the last 20 years (and possibly much longer), but monitoring programs do not typically include such sites in their studies (Hughes 1992).

It has been argued that the coral reef scientific and management community has failed the world's coral reefs (Risk 1999; Bellwood et al. 2004). In Florida, this implied failure is based on the hypothesis that diminished water quality is the single most important cause of environmental degradation in the Everglades, in Florida Bay, and on the reefs of the Florida Keys, and that the woes that beset these systems are local, human-induced, and reversible. It is easy to come away with this view after reading the literature (Lapointe 1997; Bacchus 2002; Brand 2002; Lapointe, Matzie, and Barile 2002; Lipp et al. 2002; Patterson et al. 2002; Porter et al. 2002) and being exposed to the idea as presented in the popular media (e.g., Lapointe 1989; Torrance 1991; Dustan 1997; Barnett 2003), but evidence linking nutrient loading to reef degradation remains elusive (Szmant 2002).

We contend that the focus on nutrient pollution as the primary factor responsible for the decline of coral reefs in the Florida Keys is misplaced. Unfortunately, politicians, managers, and the public are receptive to such arguments because poor sewage treatment and runoff from the Everglades Agricultural Area are things that make intuitive sense as causal agents and also have strong emotional appeal. As a result, the paradigm of nutrient pollution and coral decline has dominated debate in Florida for over 15 years. Nobody is going to argue that sewage pollution or untreated agricultural runoff is a good thing. However, intuition and emotional appeal are nonscientific approaches that seldom leave room for alternative or complementary views. One of our primary motivations for writing this chapter is that we believe it is time to move to a more balanced dynamic between the multiple stakeholders throughout south Florida and the scientists who help inform them.

Winter cold fronts, hurricanes, global warming combined with increasing ENSO intensity (causing coral bleaching), and coral and urchin diseases are stressors in the Florida Keys that have well-known cause-and-effect relationships at multiple spatial and temporal scales. These punctuated extreme events have strongly influenced the trajectory of these coral communities, yet authors advocating the primacy of diminished water quality in reef decline have essentially overlooked them. As Pennisi (1997) commented, "[The] lack of a clear smoking gun even for reefs as well studied as Florida's have been due partly to the tendency of reef scientists to focus their research on a single parameter-say, water quality." Nutrient pollution is clearly a threat, and it is possible that gradual deterioration of water quality at the regional scale has predisposed the reef biota to the sudden and radical shifts observed in the past few decades (Dubinsky and 
Stambler 1996; Vitousek et al. 1997). Management steps are already under review to clean up nearshore waters in the Florida Keys (i.e., the Florida Keys Water Quality Improvement Program; Kruczynski and McManus 2002), and systemwide water-quality and habitat-restoration efforts are ongoing under the Comprehensive Everglades Restoration Plan (Causey 2002). In 1998 the Governor of Florida issued Executive Order 98-309, directing local and state agencies to coordinate with Monroe County to eliminate cesspits, failing septic systems, and other substandard sewage systems. Additionally, in 2001 the Florida Keys Water Quality Act (Public Law 106-554) was approved by the U.S. Congress and authorized the U.S Army Corps of Engineers to provide technical and financial assistance for wastewater treatment and stormwater management projects to improve water quality of the FKNMS. When implemented, engineering solutions to improve the quality of nearshore waters certainly will not hurt the offshore reefs, and they may provide some benefit; however, it is absurd to think that the Florida reef tract will recover within our lifetime if we do not address the larger-scale causes of reef decline.

Saving coral reefs rests on our ability to forge a comprehensive, sophisticated, and accurate understanding of the mechanisms responsible for coral reef decline and regeneration. Therefore, it is imperative that managers and policymakers directly address the range of factors that have devastated coral populations and hinder their recovery. As Knowlton (2001) noted, it would be prohibitively expensive to repair reefs crippled by the negative synergistic effects of different types of stressors, including global warming and emergent diseases, yet these stressors need to be addressed at multiple scales if reefs as we know them are to survive.

\subsection{Summary and Conclusions}

By studying reef communities through the Quaternary and their changes over time, it is possible to understand more fully the history of development, structure, and function of modern reef systems. Conversely, modern reefs form the foundation for understanding the multiscale processes behind the preserved sedimentary architecture and biofacies of the fossil reef sequences. The principle of uniformitarianism forms the basis for understanding changes in reefs through time and space. Studies of Caribbean Quaternary reefs emphasize the persistence in composition and zonation over broad spatial and temporal scales. It may well be, however, that Quaternary reefs living under nonoptimal conditions, including those in Florida, may prove more useful for predicting the future trajectory of reef communities.

In this chapter, we have attempted to synthesize the Quaternary history of reef development in Florida. Using the maxim "the past is the key to the future," we have tried to tease out those factors most responsible for reef decline in Florida, both historically and recently. Living coral reefs of Florida have been in a state of flux for the past 25 years. Among these changes has been the near-elimination of the dominant coral species Acropora palmata and A. cervicornis, with concomitant increases in macroalgae. Winter cold fronts, hurricanes, global warming (causing 
coral bleaching), and coral disease are stressors in the Florida Keys that have wellknown cause-and-effect relationships. These rapid, rare, and extreme events have strongly influenced the composition of reef communities in the Florida Keys.

Whether these recent changes are natural cyclic events or the result of human activities has been a topic of strenuous debate. To address this issue, we asked the question, "Did episodes of reef degradation occur in the past, before the era of human interference, or is the current state of coral reefs unique to our time?" Because coral reefs are both geologic and biologic entities, it is possible to observe the effects of various disturbances in ecological time, detect historical changes in the paleoecological record, and deduce the multiscale processes behind those patterns. For Florida at least, the present reef community assemblage, highlighted by diminishing Acropora populations, is not unique in space or in time. This is contrary to results from other areas of the Caribbean.

Being at the northern limit of reef growth in the western Atlantic, Florida is subjected to a host of conditions unfavorable to prolific reef development. In fact, we are lucky to have reefs at all in Florida. Disease epidemics, coral bleaching events, extreme weather conditions including hurricanes and cold fronts, as well as the average annual position of the Gulf Stream affect the ecological history of reefs in Florida. Throughout the Quaternary, Florida's reefs have been subjected to numerous large-scale disturbances that have reorganized the coral community structure. Although in many cases the causes of these disturbance events have been different, the resulting community shift away from dominance by Acropora spp. has been similar. When conditions have been favorable on time scales of millennia, as in the early to middle Holocene, acroporids have dominated the shallow-reef community. When conditions have deteriorated, as in the Pleistocene, head corals have dominated and persisted. Quaternary reefs from Florida emphasize the resilience of reef ecosystems and the individualistic responses of coral species to rapid environmental change in the absence of major human modification of the seascape. These ecological shifts in coral community composition are preserved in the fossil and subfossil record of these reefs and allow us to use the past as a key to predicting the future of reefs in a world now besieged by numerous disturbances and the influence of man. As Gene Shinn has repeatedly emphasized, the story written in the geologic history of coral reefs is our most reliable guide to their uncertain future.

Acknowledgements. Many of the ideas expressed in this chapter were built on foundations provided by previous workers. In that regard, special thanks go to Gene Shinn and Barbara Lidz of the USGS for freely sharing their views on the history of the Florida reef tract. We would also like to thank Hemmo Bosscher, John Bruno, Billy Causey, Mark Chiappone, Pete Edmunds, Bill Fitt, Peter Glynn, Jack Kindinger, Les Kaufman, Joanie Kleypas, Judy Lang, Jim Leichter, Diego Lirman, Ian Macintyre, Thad Murdoch, Conrad Neumann, Harry Roberts, Caroline Rogers, and Dione Swanson for discussions over the years that led to consolidation of many of the ideas presented herein. Leslie Duncan helped with sorting out the references. Thad Murdoch drafted Fig. 9.2, and Beth Zimmer and 
Adam Gelber prepared Figs. 9.4, 9.7, and 9.8. Thad Murdoch, Martha Robbart, Barbara Lidz, Billy Causey, and Gene Shinn critiqued versions of the manuscript and Ian Macintyre, Bernhard Riegl, and Maggie Toscano provided critical reviews of the final draft. We thank Brian Keller of the FKNMS for his thoughtful analysis and editorial advice. Sincere thanks to our friend and colleague Rich Aronson for his patience and dedication in pulling this volume together and for his insight and comments throughout the entire process that greatly enhanced this chapter.

This chapter is dedicated to the memory of the late Donald R. Moore (1921-1997), Professor of Marine Geology at the University of Miami. Don was one of the early pioneers working on some of the problems discussed in this chapter. All who knew him will miss his sage advice and kind nature.

\section{References}

Adey, W.H., and R.B. Burke. 1977. Holocene bioherms of Lesser Antilles: Geologic control of development. In Reefs and Related Carbonates-Ecology and Sedimentology, eds. S.H. Frost, M.P. Weiss, and J.B. Saunders, 67-82. Studies in Geology No. 4. Tulsa: American Association of Petroleum Geologists.

Agassiz, A. 1883. The Tortugas and Florida reefs. Mem. Am. Acad. Arts Sci. 11: $107-134$.

Agassiz, A. 1896. The elevated reef of Florida. Bull. Mus. Comp. Zool. Harvard Coll. 28:1-62.

Ahr, W.M. 1973. The carbonate ramp: An alternative to the shelf model. Trans. Gulf Coast Assoc. Geol. Soc. 23:221-225.

Allen, T.F.H., and T.W. Hoeskstra. 1992. Toward a Unified Ecology. New York: Columbia University Press.

Andréfouët, S., P.J. Mumby, M. McField, C. Hu, and F.E. Muller-Karger. 2002. Revisiting coral reef connectivity. Coral Reefs 21:43-48.

Andrews, J.C., and P. Gentien. 1982. Upwelling as a source of nutrients for the Great Barrier Reef ecosystems: A solution to Darwin's question? Mar. Ecol. Prog. Ser. $8: 257-269$.

Antonius, A. 1977. Coral mortality in reefs: A problem for science and management. Proc. Third Int. Coral Reef Symp., Miami 2:617-623.

Antonius, A. 1981. The "band" diseases in coral reefs. Proc. Fourth Int. Coral Reef Symp., Manila 2:6-14.

Antonius, A. 1994a. Endangered elkhorn coral, Acropora palmata (Lamarck). In Rare and Endangered Biota of Florida Series, Vol. IV. Invertebrates, eds. M. Deyrup and R. Franz, 33-34. Gainesville: University of Florida Press.

Antonius, A. 1994b. Endangered staghorn corals, Acropora cervicornis (Lamarck), Acropora prolifera (Lamarck). In Rare and Endangered Biota of Florida Series, Vol. IV. Invertebrates, eds. M. Deyrup and R. Franz, 34-36. Gainesville: University of Florida Press.

Aronson, R.B. 1990. Onshore-offshore patterns of human fishing activity. Palaios 5:88-93.

Aronson, R.B. 1994. Scale-independent biological interactions in the marine environment. Oceanogr. Mar. Biol. Ann. Rev. 32:435-460. 
Aronson, R.B. 2001. The limits of detectability: Short-term events and short-distance variation in the community structure of coral reefs. Bull. Mar. Sci. 69:331-332.

Aronson, R.B., J.F. Bruno, W.F. Precht, P.W. Glynn, C.D. Harvell, L. Kaufman, C.S. Rogers, E.A. Shinn, and J.F. Valentine. 2003. Causes of reef degradation. Science 302:1502.

Aronson, R.B., P.J. Edmunds, W.F. Precht, D.W. Swanson, and D.R. Levitan. 1994. Largescale, long-term monitoring of Caribbean coral reefs: Simple, quick, inexpensive techniques. Atoll Res. Bull. 421:1-19.

Aronson, R.B., I.G. Macintyre, W.F. Precht, C.M. Wapnick, and T.J.T. Murdoch. 2002a. The expanding scale of species turnover events on coral reefs in Belize. Ecol. Monogr. 72:233-249.

Aronson, R.B., and W.F. Precht. 1995. Landscape patterns of reef coral diversity: A test of the intermediate disturbance hypothesis. J. Exp. Mar. Biol. Ecol. 192:1-14.

Aronson, R.B., and W.F. Precht. 1997. Stasis, biological disturbance, and community structure of a Holocene coral reef. Paleobiology 23:326-346.

Aronson, R.B., and W.F. Precht. 2000. Herbivory and algal dynamics on the coral reef at Discovery Bay, Jamaica. Limnol. Oceanogr. 45:251-255.

Aronson, R.B., and W.F. Precht. 2001a. Applied paleoecology and the crisis on Caribbean coral reefs. Palaios 16:195-196.

Aronson, R.B., and W.F. Precht. 2001b. Evolutionary paleoecology of Caribbean coral reefs. In Evolutionary Paleoecology: The Ecological Context of Macroevolutionary Change, eds. W.D. Allmon and D.J. Bottjer, 171-233. New York: Columbia University Press.

Aronson, R.B., and W.F. Precht. 2001c. White-band disease and the changing face of Caribbean coral reefs. Hydrobiologia 460:25-38.

Aronson, R.B., W.F. Precht, I.G. Macintyre, and T.J.T. Murdoch. 2000. Coral bleach-out in Belize. Nature 405:36.

Aronson, R.B., W.F. Precht, M.A. Toscano, and K.H. Koltes. 2002b. The 1998 bleaching event and its aftermath on a coral reef in Belize. Mar. Biol. 141:435-447.

Atkinson, M.J., B. Carlson, and G.L. Crow. 1995. Coral growth in high-nutrient, low-pH seawater: A case study of corals cultured at the Waikiki Aquarium, Honolulu, Hawaii. Coral Reefs 14:215-223.

Ault, J.S., J.A. Bohnsack, and G.A. Meester. 1998. A retrospective (1979-1996) multispecies assessment of coral reef fish stocks in the Florida Keys. Fish. Bull. 96:395-414.

Ault, J.S., S.G. Smith, J. Luo, G.A. Meester, J.A. Bohnsack, and S.L. Miller. 2001. Baseline multispecies coral reef fish stock assessments for the Dry Tortugas. Final Report to the National Park Service. Miami: Rosenstiel School of Marine and Atmospheric Science, University of Miami.

Bacchus, S. 2002. The "ostrich" component of the multiple stressor model: Undermining south Florida. In The Everglades, Florida Bay, and Coral Reefs of the Florida KeysAn Ecosystem Sourcebook, eds. J.W. Porter and K.G. Porter, 677-748. Boca Raton: CRC Press.

Bak, R.P.M. 1983. Aspects of community organization in Caribbean stony corals. In Coral Reefs, Seagrass Beds and Mangroves: Their Interaction in the Coastal Zones of the Caribbean, eds. J.C. Ogden and E.H. Gladfelter. UNESCO. Reports in Marine Science 23. Montevideo: UNESCO.

Bak, R.P.M., and M.S. Engel. 1979. Distribution, abundance and survival of juvenile hermatypic corals (Scleractinia) and the importance of life history strategies in the parent coral community. Mar. Biol. 54:341-352. 
Bak, R., and G. van Eys. 1975. Predation of the sea urchin Diadema antillarum Philippi on living coral. Oecologia 20:111-115.

Ball, M.M., E.A. Shinn, and R.W. Stockman. 1967. The geologic effects of Hurricane Donna in south Florida. J. Geol. 75:583-597.

Balsam, W. 1981. Late Quaternary sedimentation in the western North Atlantic: Stratigraphy and paleoceanography. Palaeogeogr. Palaeoclimatol. Palaeoecol. $35: 215-240$.

Barnett, C. 2003. 'Distress syndrome'. Florida Trend June: 74-79.

Bauer, J.C., and C.J. Agerter. 1987. Isolation of bacteria pathogenic for the sea urchin Diadema antillarum (Echinodermata: Echinoidea). Bull. Mar. Sci. 40:161-165.

Baums, I.B., M.W. Miller, and A.M. Szmant. 2003. Ecology of a corallivorous gastropod, Coralliophila abbreviata, on two scleractinian hosts. I. Population structure of snails and corals. Mar. Biol. 142:1083-1091.

Beck, J.W., J. Recy, F. Taylor, R.L. Edwards, and G. Cabioch. 1997. Abrupt changes in early Holocene tropical sea surface temperature derived from coral records. Nature 385:705-707.

Bell, P.R.F., and T. Tomascik. 1994. The demise of the fringing coral reefs of Barbados and of regions in the Great Barrier Reef (GBR) lagoon-Impacts of eutrophication. In Proceedings of the Colloquium on Global Aspects of Coral Reefs: Health, Hazards and History, compiler R.N. Ginsburg, 319-325. Miami: Rosenstiel School of Marine and Atmospheric Science, University of Miami.

Bellwood, D.R., T.P. Hughes, C. Folke, and M. Nyström. 2004. Confronting the coral reef crisis. Nature 429:827-833.

Blair, S.M., T.L. McIntosh, and B.J. Mostkoff. 1994. Impacts of Hurricane Andrew on the offshore reef systems of central and northern Dade County, Florida. Bull. Mar. Sci. 54:961-973.

Blanchon, P. 1997. Architectural variation in submerged shelf-edge reefs: The hurricane control hypothesis. Proc. Eighth Int. Coral Reef Symp., Panama 1:547-554.

Blanchon, P., B. Jones, and W. Kalbfleisch. 1997. Anatomy of a fringing reef around Grand Cayman: Storm rubble, not coral framework. J. Sediment. Res. 67:1-16.

Bloom, A.L. 1994. The coral record of late glacial sea level rise. In Proceedings of the Colloquium on Global Aspects of Coral Reefs: Health, Hazards and History, compiler R.N. Ginsburg, 1-6. Miami: Rosenstiel School of Marine and Atmospheric Science, University of Miami.

Bohnsack, J.A. 2003. Shifting baselines, marine reserves, and Leopold's biotic ethic. Gulf Carib. Res. 14:1-7.

Bohnsack, J.A., D.E. Harper, and D.B. McClellan. 1994. Fisheries trends from Monroe County, Florida. Bull. Mar. Sci. 54:982-1018.

Bosscher, H. 1992. Growth Potential of Coral Reefs and Carbonate Platforms. Amsterdam: Proefschrift Vrije Universiteit.

Boyer, J.N., and R.D. Jones. 2002. A view from the bridge: External and internal forces affecting the ambient water quality of the Florida Keys National Marine Sanctuary (FKNMS). In The Everglades, Florida Bay, and Coral Reefs of the Florida Keys-An Ecosystem Sourcebook, eds. J.W. Porter and K.G. Porter, 609-628. Boca Raton: CRC Press.

Boyer, K.E., P. Fong, A.R. Armitage, and R.A. Cohen. 2004. Elevated nutrient content of tropical macroalgae increases rates of herbivory in coral, seagrass, and mangrove habitats. Coral Reefs 23:530-538. 
Bradley, R.S. 2000. Past global changes and their significance for the future. Quat. Sci. Rev. 19:391-402.

Brand, L.E. 2002. The transport of terrestrial nutrients to south Florida coastal waters. In The Everglades, Florida Bay, and Coral Reefs of the Florida Keys-An Ecosystem Sourcebook, eds. J.W. Porter and K.G. Porter, 361-414. Boca Raton: CRC Press.

Brett, C.E., K.B. Miller, and G.C. Baird. 1990. A temporal hierarchy of paleoecologic processes within a middle Devonian epeiric sea. Paleontol. Soc. Spec. Publ. 5: 178-209.

Bright, T.J., G.P. Kraemer, G.A. Minnery, and S.T. Viada. 1984. Hermatypes of the Flower Garden Banks, northwestern Gulf of Mexico: A comparison to other western Atlantic reefs. Bull. Mar. Sci. 34:461-476.

Broecker, W.S., and D.L. Thurber. 1964. Uranium-series dating of corals and oolites from Bahaman and Florida Keys limestone. Science 149:58-60.

Brown, B.E. 1997. Disturbances to reefs in recent times. In Life and Death of Coral Reefs, ed. C. Birkeland, 354-379. New York: Chapman and Hall.

Brown, J.H. 1984. On the relationship between abundance and distribution of species. Am. Nat. 124:255-279.

Bruckner, A.W. 2002. Priorities for Effective Management of Coral Diseases. NOAA Tech. Mem. NMFS-OPR-22.

Bruckner, A.W., R.J. Bruckner, and E.H. Williams, Jr. 1997. Spread of a black-band disease epizootic through the reef system in St. Ann's Bay, Jamaica. Bull. Mar. Sci. 61:919-928.

Bruckner, R.J., A.W. Bruckner, and E.H. Williams, Jr. 1997. Life history strategies of Coralliophila abbreviata Lamarck (Gastropoda: Coralliophilidae) on the southwest coast of Puerto Rico. Proc. Eighth Int. Coral Reef Symp., Panama 1: 627-632.

Bruno, J.F., L.E. Petes, C.D. Harvell, and A. Hettinger. 2004. Nutrient enrichment can increase the severity of coral diseases. Ecol. Lett. 6:1056-1061.

Bryant, D., L. Burke, J. McManus, and M. Spalding. 1998. Reefs at Risk-A Map-Based Indicator to Threats to the World's Coral Reefs. Washington, DC: World Resources Institute.

Budd, A.F., K.G. Johnson, and T.A. Stemann. 1994. Plio-Pleistocene extinctions and the origin of the modern Caribbean reef-coral fauna. In Proceedings of the Colloquium on Global Aspects of Coral Reefs: Health, Hazards and History, 1993, compiler R.N. Ginsburg, 7-13. Miami: Rosenstiel School of Marine and Atmospheric Science, University of Miami.

Buddemeier, R.W. 2001. Is it time to give up? Bull. Mar. Sci. 69:317-326.

Buddemeier, R.W., and R.A. Kinzie III. 1998. Reef science: Asking all the wrong questions in all the wrong places? Reef Encounter 23:29-34.

Buddemeier, R.W., J.A. Kleypas, and R.B. Aronson. 2004. Coral Reefs and Global Climate Change: Potential Contributions of Climate Change to Stresses on Coral Reef Ecosystems. Arlington, VA: Pew Center on Global Climate Change.

Burns, T.P. 1985. Hard-coral distribution and cold-water disturbances in south Florida. Coral Reefs 4:117-124.

Bythell, J.C., E.H. Gladfelter, and M. Bythell. 1993. Chronic and catastrophic natural mortality of three common Caribbean reef corals. Coral Reefs 12:143-152.

Bythell, J.C., Z.M. Hillis-Starr, and C.S. Rogers. 2000. Local variability but landscape stability in coral reef communities following repeated hurricane impacts. Mar. Ecol. Prog. Ser. 204:93-100. 
Bythell, J.C., and C. Sheppard. 1993. Mass mortality of Caribbean shallow corals. Mar. Pollut. Bull. 26:296-297.

Cale, W.G., G.M. Henebry, and J.A. Yeakley. 1989. Inferring process from pattern in natural communities. BioScience 39:600-605.

Carpenter, R.C. 1990a. Mass mortality of Diadema antillarum. 1. Long-term effects on sea urchin population dynamics and coral reef algal communities. Mar. Biol. 104:67-77.

Carpenter, R.C. 1990b. Mass mortality of D. antillarum. 2. Effects on population densities and grazing intensity of parrotfishes and surgeonfishes. Mar. Biol. 104:79-86.

Causey, B.D. 2001. Lessons learned from the intensification of coral bleaching from 1980-2000 in the Florida Keys, USA. In Coral Bleaching and Marine Protected Areas. Proceedings of the Workshop on Mitigating Coral Bleaching Impact through MPA Design, eds. R.V. Salm and S.L. Coles, 60-66. Honolulu: Asia Pacific Coastal Marine Program Report \#0102.

Causey, B.D. 2002. The role of the Florida Keys National Marine Sanctuary in the south Florida ecosystem restoration initiative. In The Everglades, Florida Bay, and Coral Reefs of the Florida Keys—An Ecosystem Sourcebook, eds. J.W. Porter and K.G. Porter, 883-894. Boca Raton: CRC Press.

Causey, B., J. Delaney, E. Diaz, D. Dodge, J.R. Garcia, J. Higgins, W. Jaap, C.A. Matos, G.P. Schmahl, C. Rogers, M.W. Miller, and D.D. Turgeon. 2000. Status of coral reefs in the US Caribbean and Gulf of Mexico: Florida, Texas, Puerto Rico, U.S. Virgin Islands and Navassa. In Status of Coral Reefs of the World: 2000, ed. C. Wilkinson, 239-259. Cape Ferguson: Australian Institute of Marine Science.

Causey, B., G. Garrett, B. Haskell, W. Jaap, and A. Szmant. 1998. The 1997-1998 mass bleaching event around the world-Florida (USA). In Status of Coral Reefs of the World: 1998, ed. C. Wilkinson, 34-35. Cape Ferguson: Australian Institute of Marine Science.

Chappell, J. 1983. Sea level changes and coral reef growth. In Perspectives on Coral Reefs, ed. D.J. Barnes, 46-55. Manuka: Brian Clouston.

Chappell, J., and N.J. Shackleton. 1986. Oxygen isotopes and sea level. Nature 324:137-140.

Chiappone, M. 1996. Coral Watch program summary. A report on volunteer and scientific efforts to document the status of reefs in the Florida Keys National Marine Sanctuary. Summerland Key: The Nature Conservancy.

Chiappone, M., S.L. Miller, and D.W. Swanson. 2002. Status of Acropora corals in the Florida Keys: Habitat utilization, coverage, colony density, and juvenile recruitment. In Proceedings of the Caribbean Acropora Workshop: Potential Application of the U.S. Endangered Species Act as a Conservation Strategy, ed. A. Bruckner, 125-135. NOAA-OPR-24.

Chiappone, M., S.L. Miller, D.W. Swanson, J.S. Ault, and S.G. Smith. 2001. Comparatively high densities of the long-spined sea urchin in the Dry Tortugas, Florida. Coral Reefs 20:137-138.

Chiappone, M., and K.M. Sullivan. 1994. Ecological structure and dynamics of nearshore hard-bottom communities in the Florida Keys. Bull. Mar. Sci. 54:747-756.

Chiappone, M., and K.M. Sullivan. 1997. Rapid assessment of reefs in the Florida Keys: Results from a synoptic survey. Proc. Eighth Int. Coral Reef Symp., Panama 2:1509-1514.

Cho, L.L., and J.D. Woodley. 2002. Recovery of reefs at Discovery Bay, Jamaica and the role of D. antillarum. Proc. Ninth Int. Coral Reef Symp., Bali 1:331-338.

Clarke, A.H., D.J. Stanley, J.C. Medcof, and R.E. Drinnan. 1967. Ancient oyster and bay scallop shells from Sable Island. Nature 215:1146-1148. 
CLIMAP Project Members. 1976. The surface of the ice-age earth. Science 191:1131-1144.

COHMAP Members. 1988. Climatic changes of the last 18,000 years: Observations and model simulations. Science 241:1043-1052.

Coniglio, M., and R.S. Harrison. 1983. Facies and diagenesis of late Pleistocene carbonates from Big Pine Key, Florida. Bull. Can. Pet. Geol. 31:135-147.

Connell, J.H. 1978. Diversity in tropical rain forests and coral reefs. Science 199:1302-1310.

Connell, J.H. 1997. Disturbance and recovery of coral assemblages. Coral Reefs 16:S101-S113.

Cook, C.B., E.M. Mueller, M.D. Ferrier, and E. Annis. 2002. The influence of nearshore waters on corals of the Florida Reef Tract. In The Everglades, Florida Bay, and Coral Reefs of the Florida Keys-An Ecosystem Sourcebook, eds. J.W. Porter and K.G. Porter, 771-788. Boca Raton: CRC Press.

Corbett, D.R., J. Chanton, W. Burnett, K. Dillon, C. Rutkowski, and J.W. Fourqurean. 1999. Patterns of groundwater discharge into Florida Bay. Limnol. Oceanogr. 44:1045-1055.

Cortés, J. 1994. A reef under siltation stress: A decade of degradation. In Proceedings of the Colloquium on Global Aspects of Coral Reefs: Health, Hazards and History, compiler R.N. Ginsburg, 240-246. Miami: Rosenstiel School of Marine and Atmospheric Science, University of Miami.

Cortés, J., M.M. Murillos, H.M. Guzman, and J. Acuna. 1984. Perdida de zooxantelas y muerte de corales y otros organismos arrecifales en el Atlantico y Pacifico de Costa Rica. Rev. Biol. Trop. 32:227-231.

Cronin, T.M., B.J. Szabo, T.A. Ager, J.E. Hazel, and J.P. Owens. 1981. Quaternary climates and sea levels of the U.S. Atlantic Coastal Plain. Science 211:233-240.

Crowley, T.J. 2000. CLIMAP SSTs re-visited. Clim. Dynam. 16:241-255.

Dahlgren, T.G., J.R. Weinberg, and K.M. Halanych. 2000. Phylogeography of the ocean quahog (Artica islandica): Influences of paleoclimate on genetic diversity and species range. Mar. Biol. 137:487-495.

Dana, J.D. 1843. On the temperature limiting the distribution of corals. Am. J. Sci. 45:130-131.

Davidson, M.G. 2002. Protecting coral reefs: Principal national and international legal instruments. Harv. Eniviron. Law Rev. 26:499-546.

Davidson, O.G. 1998. Once more to the Keys. In The Enchanted Braid-Coming to Terms with Nature on the Coral Reefs, 207-224. New York: John Wiley \& Sons.

Davis, G.E. 1982. A century of natural change in coral distribution at the Dry Tortugas: A comparison of reef maps from 1881 and 1976. Bull. Mar. Sci. 32:608-623.

Davis, R.A., A.C. Hine, and E.A. Shinn. 1992. Holocene coastal development on the Florida Peninsula. In Quaternary Coasts of the United States: Marine and Lacustrine Systems, eds. C. Fletcher and J. Wehmiller, 193-212. SEPM Special Publication 48. Tulsa: Society for Sedimentary Geology.

Delcourt, H.R., and P.A. Delcourt. 1991. Quaternary Ecology-A Paleoecological Perspective. London: Chapman \& Hall.

de Ruyter van Steveninck, E.D., L.L. Van Mulekon, and A.M. Breenan. 1988. Growth inhibition of Lobophora variegata (Lamouroux) Womersley by scleractinian corals. J. Exp. Mar. Biol. Ecol. 115:169-178.

Dodd, R., D.E. Hattin, and R.M. Liebe. 1973. Possible living analog of the Pleistocene Key Largo reefs of Florida. Geol. Soc. Am. Bull. 84:3995-4000.

Dodge, R.E., A. Logan, and A. Antonius. 1982. Quantitative reef assessment studies in Bermuda: A comparison of methods and preliminary results. Bull. Mar. Sci. 32:745-760. 
Done, T.J. 1999. Coral community adaptability to environmental change at the scales of regions, reefs and reef zones. Am. Zool. 39:66-79.

Dubinsky, Z., and N. Stambler. 1996. Marine pollution and coral reefs. Global Change Biol. 2:511-526.

Dustan, P. 1977. Vitality of coral populations off Key Largo, Florida: Recruitment and mortality. Environ. Geol. 2:51-58.

Dustan, P. 1994. Developing methods for assessing coral reef vitality: A tale of two scales. In Proceedings of the Colloquium on Global Aspects of Coral Reefs: Health, Hazards and History, compiler R.N. Ginsburg, 38-44. Miami: Rosenstiel School of Marine and Atmospheric Science, University of Miami.

Dustan, P. 1997. What is killing our coral reefs? Calypso Log October.

Dustan, P., and J.C. Halas. 1987. Changes in the reef-coral community of Carysfort Reef, Key Largo, Florida: 1974-1982. Coral Reefs 6:91-106.

Dyke, A.S., J.E. Dale, and R.N. McNelly. 1996. Marine molluscs as indicators of environmental change in glaciated North America and Greenland during the last 18,000 years. Geogr. Phys. Quat. 50:125-184.

Eakin, C.M., J.W. McManus, M.D. Spalding, and S.C. Jameson. 1997. Coral reef status around the world: Where are we and where do we go from here? Proc. Eighth Int. Coral Reef Symp., Panama 1:277-282.

Easterling, D.R., G.A. Meehl, C. Parmesan, S.A. Changnon, T.R. Karl, and L.O. Mearns. 2000. Climate extremes: Observations, modeling, and impacts. Science 289:2068-2074.

Edmunds, P.J. 1991. Extent and effect of black-band disease on a Caribbean reef. Coral Reefs 10:161-165.

Edmunds, P.J., R.B. Aronson, D.W. Swanson, D.R. Levitan, and W.F. Precht. 1998. Photographic versus visual census techniques for the quantification of juvenile corals. Bull. Mar. Sci. 62:437-446.

Edmunds, P.J., and J.F. Bruno. 1996. The importance of sampling scale in ecology: Kilometerwide variation in coral reef communities. Mar. Ecol. Prog. Ser. 143:165-171.

Edmunds, P.J., and R.C. Carpenter. 2001. Recovery of Diadema antillarum reduces macroalgal cover and increases abundances of juvenile corals on a Caribbean reef. Proc. Natl. Acad. Sci. USA 98:5067-5071.

Edmunds, P.J., R.D. Gates, and D.F. Gleason. 2003. The tissue composition of Montastraea franksi during a natural bleaching event in the Florida Keys. Coral Reefs 22:54-62.

Enos, P. 1977. Holocene sediment accumulations of the south Florida shelf margin. In Quaternary Sedimentation in South Florida, Memoir 147, eds. P. Enos and R.D. Perkins, 1-130. Boulder: Geological Society of America.

Epstein, P.R., B. Sherman, E. Spanger-Siegfried, A. Langston, S. Prasad, and B. McKay. 1998. Marine ecosystems-Emerging diseases as indicators of change. Health Ecological and Economic Dimensions of Global Change Program. Cambridge: Harvard University.

Evans, C.C. 1987. The relationship between the topography and internal structure of an ooid shoal sand complex: The upper Pleistocene Miami Limestone. Miami Geol. Soc. Mem. 3:18-41.

Fairbanks, R.G. 1989. A 17,000-year glacio-eustatic sea level record: Influence of glacial melting rates on the Younger Dryas event and deep-ocean circulation. Nature 342:637-642.

Fairbanks, R.G. 1990. The age and origin of the "Younger Dryas Climate Event" in Greenland ice cores. Paleoceanography 5:937-948. 
Fitt, W.K., B.E. Brown, M.E. Warner, and R.P. Dunne. 2001. Coral bleaching: Interpretation of thermal tolerance limits and thermal thresholds in tropical corals. Coral Reefs 20:51-65.

Fitt, W.K., H.J. Spero, J. Halas, M.W. White, and J.W. Porter. 1993. Recovery of the coral Montastrea annularis in the Florida Keys after the 1987 Caribbean "bleaching event." Coral Reefs 12:57-64.

FMRI. 1998. Benthic Habitats of the Florida Keys. Tech. Report TR-3. St. Petersburg: Florida Marine Research Institute.

Folland, C.K., T.R. Karl, and K.Ya. Vinnikov. 1990. Observed climate variations and change. In Climate Change, The IPCC Scientific Assessment, eds. J.T. Houghton, G.J. Jenkins, and J.J. Ephraums, 195-238. Cambridge: Cambridge University Press.

Fong, P., and D. Lirman. 1995. Hurricanes cause population expansion of the branching coral Acropora palmata (Scleractinia): Wound healing and growth patterns of asexual recruits. Mar. Ecol. 16:317-335.

Forcucci, D. 1994. Population density, recruitment and 1991 mortality event of Diadema antillarum in the Florida Keys. Bull. Mar. Sci. 54:917-928.

Foster, D.R., P.K. Schoonmaker, and S.T.A. Pickett. 1990. Insights from paleoecology to community ecology. Trends Ecol. Evol. 5:119-122.

Fourqurean, J.W., and J.C. Zieman. 2002. Seagrass nutrient content reveals regional patterns of relative availability of nitrogen and phosphorous in the Florida Keys, FL, USA. Biogeochemistry 61:229-245.

Friedman, G.M. 1977. The Bahamas and southern Florida: A model for carbonate deposition. In Field Guide to Some Carbonate Rock Environments-Florida Keys and Western Bahamas, ed. H.G. Multer, 384-391. Dubuque: Kendall/Hunt.

Fruijtier, C., T. Elliott, and W. Schlager. 2000. Mass-spectrometric ${ }^{234} \mathrm{U}^{230} \mathrm{Th}$ ages from the Key Largo Formation, Florida Keys, United States: Constraints on diagenetic age disturbance. Geol. Soc. Am. Bull. 112:267-277.

Gardner, T.A., I.M. Côté, J.A. Gill, A. Grant, and A.R. Watkinson. 2003. Long-term region-wide declines in Caribbean corals. Science 301:958-960.

Gardner, T.A., I.M. Côté, J.A. Gill, A. Grant, and A.R. Watkinson. 2005. Hurricanes and Caribbean coral reefs: Impacts, recovery patterns, and role in long-term decline. Ecology 86:174-184.

Garrett, P., and P. Ducklow. 1975. Coral disease in Bermuda. Nature 253:349-350.

Garzon-Ferreira, J., D.L. Gil-Agudelo, L.M. Barrios, and S. Zea. 2001. Stony coral diseases observed in southwestern Caribbean reefs. Hydrobiologia 460:65-69.

Geister, J. 1977. The influence of wave exposure on the ecological zonation of Caribbean coral reefs. Proc. Third Int. Coral Reef Symp., Miami 1:23-29.

Geister, J. 1980. Calm-water reefs and rough-water reefs of the Caribbean Pleistocene. Acta Palaeontol. Polon. 25:541-556.

Geister, J. 1983. Holozäne westindische Korallenriffe: Geomorphologie, Ökologie und Fazies. Facies 9:173-284.

Gentry, R.C. 1984. Hurricanes in south Florida. In Environments of South Florida Present and Past II, ed. P.J. Gleason, 510-519. Coral Gables: Miami Geological Society.

Gill, I., D. Hubbard, and J.A.D. Dickson. 1999. Corals, reefs, and six millennia of Holocene climate. 11th Bathurst Meeting, Cambridge, J. Conf. Abs. 4:921.

Gilmore, M.D., and B.R. Hall. 1976. Life history, growth habits, and constructional roles of Acropora cervicornis in the patch reef environment. J. Sediment. Petrol. 40:519-522.

Ginsburg, R.N. (compiler). 1994. Proceedings of the Colloquium on Global Aspects of Coral Reefs: Health, Hazards and History. Miami: Rosenstiel School of Marine and Atmospheric Science, University of Miami. 
Ginsburg, R.N., E. Gischler, and W.E. Kiene. 2001. Partial mortality of massive reef-building corals: An index of patch reef condition, Florida reef tract. Bull. Mar. Sci. 69:1149-1173.

Ginsburg, R.N., and N.P. James. 1974. Spectrum of Holocene reef-building communities in the western Atlantic. In Principles of Benthic Community Analysis, Sedimenta IV, eds. A.M. Ziegler, K.R. Walker, E.J. Anderson, E.G. Kauffman, R.N. Ginsburg, and N.P. James, 7.1-7.22. Miami: Rosenstiel School of Marine and Atmospheric Science, University of Miami.

Ginsburg, R.N., and E.A. Shinn. 1964. Distribution of the reef-building community in Florida and the Bahamas. Am. Assoc. Petrol. Geol. Bull. 48:527.

Ginsburg, R.N., and E.A. Shinn. 1994. Preferential distribution of reefs in the Florida Reef Tract: The past is the key to the present. In Proceedings of the Colloquium on Global Aspects of Coral Reefs: Health, Hazards and History, compiler R.N. Ginsburg, 21-26. Miami: Rosenstiel School of Marine and Atmospheric Science, University of Miami.

Gittings, S.R., K.J.P. Deslarzes, D.K. Hagman, and G.S. Boland. 1992. Reef coral populations and growth at the Flower Garden Banks, northwest Gulf of Mexico. Proc. Seventh Int. Coral Reef Symp., Guam 1:90-96.

Gladfelter, W.B. 1982. White band disease in Acropora palmata: Implications for the structure and growth of shallow reefs. Bull. Mar. Sci. 32:639-643.

Gleason, P.J. 1984. Saving the wild places—a necessity for growth. In Environments of South Florida Past and Present II, ed. P.J. Gleason, viii-xxiii. Coral Glabes: Miami Geological Society.

Glynn, P.W. 1973. Aspects of the ecology of coral reefs in the western Atlantic region. In Biology and Geology of Coral Reefs, eds. O.A. Jones and R. Endean, 271-324. New York: Academic Press.

Glynn, P.W. 1983. Extensive bleaching and death of reef corals on the Pacific coast of Panama. Environ. Conserv. 10:149-154.

Glynn, P.W. 1991. Coral reef bleaching in the 1980's and possible connections with global warming. Trends Ecol. Evol. 6:175-179.

Glynn, P.W. 1993. Coral reef bleaching: Ecological perspectives. Coral Reefs 12:1-17.

Glynn, P.W. 1996. Coral reef bleaching: Facts, hypotheses and implications. Global Change Biol. 2:495-509.

Glynn, P.W., L.R. Almodóvar, and J.G. González. 1964. Effects of Hurricane Edith on marine life in La Parguera, Puerto Rico. Caribb. J. Sci. 4:335-345.

Glynn, P.W., and L. D'Croz. 1990. Experimental evidence for high temperature stress as the cause of El Niño-coincident coral mortality. Coral Reefs 8:181-191.

Goldberg, W.M. 1973. The ecology of the coral-octocoral communities off the southeast Florida coast: Geomorphology, species composition, and zonation. Bull. Mar. Sci. 23:465-487.

Goreau, T.F. 1959. The ecology of Jamaican coral reefs. I. Species composition and zonation. Ecology 40:67-90.

Goreau, T.F. 1969. Post Pleistocene urban renewal in coral reefs. Micronesica 5:323-326.

Goreau, T.F., and N.I. Goreau. 1973. The ecology of Jamaican coral reefs. II. Geomorphology, zonation and sedimentary phases. Bull. Mar. Sci. 23:399-464.

Gould, S.J. 1981. Palaeontology plus ecology as palaeobiology. In Theoretical Ecology: Principles and Applications, ed. R.M. May, 295-317. Sunderland: Sinauer Associates.

Graus, R.R., and I.G. Macintyre. 1989. The zonation of Caribbean coral reefs as controlled by wave and light energy input, bathymetric setting and reef morphology: Computer simulation experiments. Coral Reefs 8:9-18. 
Graus, R.R., and I.G. Macintyre. 1998. Global warming and the future of Caribbean coral reefs. Carbonates and Evaporites 13:43-47.

Graus, R.R., I.G. Macintyre, and B.E. Herchenroder. 1984. Computer simulation of the reef zonation at Discovery Bay, Jamaica: Hurricane disruption and long-term physical oceanographic controls. Coral Reefs 3:59-68.

Greenstein, B.J., and H.A. Curran. 1997. How much ecological information is preserved in fossil reefs and how reliable is it? Proc. Eighth Int. Coral Reef Symp., Panama 1:417-422.

Greenstein, B.J., H.A. Curran, and J.M. Pandolfi. 1998. Shifting ecological baselines and the demise of Acropora cervicornis in the Western Atlantic and Caribbean Province: A Pleistocene perspective. Coral Reefs 17:249-261.

Greenstein, B.J., L.A. Harris, and H.A. Curran. 1998. Comparison of recent coral life and death assemblages to Pleistocene reef communities: Implications for rapid faunal replacement on recent reefs. Carbonates and Evaporites 13:23-31.

Greenstein, B.J., and J.M. Pandolfi. 1997. Preservation of community structure in modern coral life and death assemblages of the Florida Keys: Implications for the Quaternary fossil record of coral reefs. Bull. Mar. Sci. 61:431-452.

Greenstein, B.J., J.M. Pandolfi, and H.A. Curran. 1998. The completeness of the Pleistocene fossil record: Implications for stratigraphic adequacy. In The Adequacy of the Fossil Record. eds. S.K. Donovan and C.R.C. Paul, 75-109. London: Wiley.

Guilderson, T.P., R.G. Fairbanks, and J.L. Rubenstone. 1994. Tropical temperature variations since 20,000 years ago: Modulating interhemispheric climate change. Science 263:663-665.

Halley, R.B., and C.C. Evans. 1983. The Miami Limestone-A Guide to Selected Outcrops and their Interpretation. Miami Geological Society Publications.

Halley, R.B., H.L. Vacher, and E.A. Shinn. 1997. Geology and hydrogeology of the Florida Keys. In Geology and Hydrogeology of Carbonate Islands, eds. H.L. Vacher and T.M. Quinn, 217-248. New York: Elsevier.

Hallock, P., F.E. Muller-Karger, and J.C. Halas. 1993. Coral reef decline. Natl. Geogr. Res. Expl. 9(3):358-378.

Hanisak, M.D., and L.W. Siemon. 1999. Macroalgal tissue nutrients as indicators of nitrogen and phosphorus status in the Florida Keys. J. Phycol. 14:28.

Harrison, R.S., and M. Coniglio. 1985. Origin of the Pleistocene Key Largo Limestone, Florida Keys. Bull. Can. Soc. Petrol. Geol. 33:350-358.

Harrison, R.S., L.D. Cooper, and M. Coniglio. 1984. Late Pleistocene carbonates of the Florida Keys. In Carbonates in Subsurface and Outcrop, 291-306. 1984 CSPG Core Conference, Alberta: Canadian Society of Petroleum Geologists.

Harvell, C.D., K. Kim, J.M. Burkholder, R.R. Colwell, P.R. Epstein, D.J. Grimes, E.E. Hofmann, E.K. Lipp, A.D.M.E. Osterhaus, R.M. Overstreet, J.W. Porter, G.W. Smith, and G.R. Vasta. 1999. Emerging marine diseases-Climate links and anthropogenic factors. Science 285:1505-1510.

Hay, M.E. 1981. Herbivory, algal distribution, and the maintenance of between-habitat diversity on a tropical fringing reef. Am. Nat. 118:520-540.

Hay, M.E. 1984. Patterns of fish and urchin grazing on Caribbean coral reefs: Are previous results typical? Ecology 65:446-454.

Hay, M.E., and T. Goertemiller. 1983. Between-habitat differences in herbivore impact on Caribbean coral reefs. In The Ecology of Deep and Shallow Coral Reefs, ed. M.L. Reaka, 97-102. Washington, DC: NOAA Symposia Series for Undersea Research. 
Hay, M.E., and P.R. Taylor. 1985. Competition between herbivorous fishes and urchins on Caribbean reefs. Oecologia 65:591-598.

Hayes, M.L., J. Bonaventura, T.P. Mitchell, J.M. Prospero, E.A. Shinn, F. Van Dolah, and R.T. Barber. 2001. How are climate and marine biological outbreaks functionally linked? Hydrobiologia 460:213-220.

Hayes, R.L., and N.I. Goreau. 1998. The significance of emerging diseases in the tropical coral reef ecosystem. Rev. Biol. Trop. 46:173-185.

Highsmith, R.C. 1982. Reproduction by fragmentation in corals. Mar. Ecol. Prog. Ser. 7:207-226.

Highsmith, R.C., A.C. Riggs, and C.M. D'Antonio. 1980. Survival of hurricane-generated coral fragments and a disturbance model of reef calcification/growth rates. Oecologia 46:322-329.

Hine, A.C. 1997. Structural and paleoceanographic evolution of the margins of the Florida platform. In The Geology of Florida, eds. A.F. Randazzo and D.S. Jones, 169-194. Gainesville: University Press of Florida.

Hodges, L.T. 1977. Coral size and orientation relationships of the Key Largo Limestone of Florida. Proc Third Int. Coral Reef Symp., Miami 2:347-352.

Hoegh-Guldberg, O. 1999. Climate change, coral bleaching and the future of the world's coral reefs. Mar. Freshwater Res. 50:839-866.

Hoffmeister, J.E. 1974. Land from the Sea-A Geologic Story of South Florida. Miami: University of Miami Press.

Hoffmeister, J.E., J.I. Jones, J.D. Milliman, D.R. Moore, and H.G. Multer. 1964. Living and Fossil Reef Types of South Florida. Field Trip No. 3. Miami: Geological Society of America.

Hoffmeister, J.E., and H.G. Multer. 1964. Growth rate estimates of a Pleistocene coral reef of Florida. Geol. Soc. Am. Bull. 75:353-358.

Hoffmeister, J.E., and H.G. Multer. 1968. Geology and origin of the Florida Keys. Geol. Soc. Am. Bull. 79:1487-1502.

Holden, C. 1996. Coral disease hot spot in Florida Keys. Science 274:2017.

Holland, S.M. 2000. The quality of the fossil record: A sequence stratigraphic approach. Paleobiology 26:148-168.

Hu, C., K.E. Hackett, M.K. Callahan, S. Andréfouët, J.L. Wheaton, J.W. Porter, and F.E. Muller-Karger. 2003. The 2002 ocean color anomaly in the Florida Bight: A cause of local coral reef decline? Geophys. Res. Lett. 30:1151.

Hubbard, D.K. 1988. Controls of modern and fossil reef development: Common ground for biological and geological research. Proc. Sixth Int. Coral Reef Symp., Townsville $1: 243-252$.

Hubbard, D.K., E.H. Gladfelter, and J.C. Bythell. 1994. Comparison of biological and geological perspectives of coral-reef community structure at Buck Island, U.S. Virgin Islands. In Proceedings of the Colloquium on Global Aspects of Coral Reefs: Health, Hazards and History, compiler R.N. Ginsburg, 201-207. Miami: Rosenstiel School of Marine and Atmospheric Science, University of Miami.

Hubbard, D.K., K.M. Parsons, J.C. Bythell, and N.D. Walker. 1991. The effects of Hurricane Hugo on the reefs and associated environments of St. Croix, U.S. Virgin Islands. J. Coast. Res. Spec. Iss. 8:33-48.

Hudson, J.H. 1981a. Growth rates in Montastraea annularis: A record of environmental change in Key Largo Coral Reef Marine Sanctuary, Florida. Bull. Mar. Sci. 31:444-459. 
Hudson, J.H. 1981b. Response of Montastraea annularis to environmental change in the Florida Keys. Proc. Fourth Int. Coral Reef Symp., Manila 2:233-40.

Hudson, J.H., K.J. Hanson, R.B. Halley, and J.L. Kindinger. 1994. Environmental implications of growth rate changes in Montastraea annularis: Biscayne National Park, Florida. Bull. Mar. Sci. 54:647-669.

Hughes, T.P. 1985. Life histories and population dynamics of early successional corals. Proc. Fifth Int. Coral Reef Congr., Tahiti 4:101-106.

Hughes, T.P. 1989. Community structure and diversity of coral reefs: The role of history. Ecology 70:275-279.

Hughes, T.P. 1992. Monitoring of coral reefs: A bandwagon? Reef Encounter 11:9-11.

Hughes, T.P. 1994. Catastrophes, phase shifts and large-scale degradation of a Caribbean coral reef. Science 265:1547-1551.

Hughes, T.P., A.H. Baird, D.R. Bellwood, M. Card, S.R. Connolly, C. Folke, R. Grosberg, O. Hoegh-Guldberg, J.B.C. Jackson, J. Kleypas, J.M. Lough, P. Marshall, M. Nyström, S.R. Palumbi, J.M. Pandolfi, B. Rosen, and J. Roughgarden. 2003. Climate change, human impacts, and the resilience of coral reefs. Science 301:929-933.

Hughes, T.P., and J.H. Connell. 1999. Multiple stressors on coral reefs: A long-term perspective. Limnol. Oceanogr. 44:932-940.

Hughes, T.P., A.M. Szmant, R. Steneck, R. Carpenter, and S. Miller. 1999. Algal blooms on coral reefs: What are the causes? Limnol. Oceanogr. 44:1583-1586.

Hughes, T.P., and J.E. Tanner. 2000. Recruitment failure, life histories, and long-term decline of Caribbean corals. Ecology 81:2250-2263.

Hunter, I.G., and B. Jones. 1996. Coral associations of the Pleistocene Ironshore Formation, Grand Cayman. Coral Reefs 15:249-267.

Huston, M.A. 1985. Patterns of species diversity on coral reefs. Ann. Rev. Ecol. Syst. 16:149-177.

Hutton, J. 1785. The system of the earth, its duration, and stability. Abstracted from a dissertation read to the Royal Society of Edinburgh in 1785. In Philosophy of Geohistory: 1785-1970, ed. C.C. Albritton, Jr., 24-52. Stroudsburg: Dowden, Hutchinson \& Ross.

Idjadi, J.A., S.C. Lee, J.F. Bruno, W.F. Precht, L. Allen-Requa, and P.J. Edmunds. 2006. Rapid phase-shift reversal on a Jamaican coral reef. Coral Reefs.

Jaap, W.C. 1979. Observations on zooxanthellae expulsion at Middle Sambo Reef, Florida Keys. Bull. Mar. Sci. 29:414-422.

Jaap, W.C. 1984. The ecology of the south Florida coral reefs: A community profile. FWS OBS-82/08 and MMS 84-0038.

Jaap, W.C. 1985. An epidemic zooxanthellae expulsion during 1983 in the lower Florida Keys coral reefs: Hyperthermic etiology. Proc. Fifth Int. Coral Reef Congr., Tahiti 6:142-148.

Jaap, W.C. 1994. Coral and coral reef management. In Rare and Endangered Biota of Florida Series, Vol. IV. Invertebrates, eds. M. Deyrup and R. Franz, 26-29. Gainesville: University Press of Florida.

Jaap, W.C. 1998. Boom-bust cycles in Acropora. Reef Encounter 23:12-13.

Jaap, W.C., J.C. Halas, and R.G. Muller. 1988. Community dynamics of stony corals (Milleporina and Scleractinia) at Key Largo National Marine Sanctuary, Florida, during 1981-1986. Proc. Sixth Int. Coral Reef Symp., Townsville 2:237-243.

Jaap, W.C., and P. Hallock. 1990. Coral reefs. In Ecosystems of Florida, eds. R.L. Meyers and J.J. Ewel, 574-616. Orlando: University of Central Florida Press.

Jaap, W.C., J.W. Porter, J. Wheaton, K. Hackett, M. Lybolt, M.K. Callahan, C. Tsokos, and G. Yanev. 2001. EPA/FKNMS Coral Reef Monitoring Project: Updated executive summary, 1996-2000. Report to Steering Committee, August 2001. 
Jaap, W.C., and F.J. Sargent. 1994. The status of the remnant population of Acropora palmata (Lamarck, 1816) at Dry Tortugas National Park, Florida, with a discussion of possible causes of changes since 1881. In Proceedings of the Colloquium on Global Aspects of Coral Reefs: Health, Hazards and History, compiler R.N. Ginsburg, 101-105. Miami: Rosenstiel School of Marine and Atmospheric Science, University of Miami.

Jackson, J.B.C. 1991. Adaptation and diversity of reef corals. BioScience 41:475-482.

Jackson, J.B.C. 1992. Pleistocene perspectives of coral reef community structure. Am. Zool. 32:719-731.

Jackson, J.B.C. 1994. Community unity? Science 264:1412-1413.

Jackson, J.B.C. 2001. What was natural in the coastal oceans? Proc. Natl. Acad. Sci. USA 98:5411-5418.

Jackson, J.B.C., A.F. Budd, and J.M. Pandolfi. 1996. The shifting balance of natural communities? In Evolutionary Paleoecology, eds. D. Jablonski, D.H. Erwin, and J.H. Lipps, 89-112. Chicago: University of Chicago Press.

Jackson, J.B.C., and K.G. Johnson. 2000. Life in the last few million years. Paleobiology 26:221-235.

Jackson, J.B.C., M.X. Kirby, W.H. Berger, K.A. Bjorndal, L.W. Botsford, B.J. Bourque, R.H. Bradbury, R. Cooke, J. Erlandson, J.A. Estes, T.P. Hughes, S. Kidwell, C.B. Lange, H.S. Lenihan, J.M. Pandolfi, C.H. Peterson, R.S. Steneck, M.J. Tegner, and R.R. Warner. 2001. Historical overfishing and the recent collapse of coastal ecosystems. Science 293:629-638.

Jackson, S.T., and J.T. Overpeck. 2000. Responses of plant populations and communities to environmental changes of the late Quaternary. Paleobiology 26:194-220.

James, N.P., C.W. Stern, and R.S. Harrison. 1977. Field Guide Book to Modern and Pleistocene Reef Carbonates-Barbados. Miami: Third International Coral Reef Symposium.

Jameson, S.C., M.H. Tupper, and J.M. Ridley. 2002. The three screen doors: Can marine "protected" areas be effective? Mar. Pollut. Bull. 44:1177-1183.

Jokiel, P., and S. Coles. 1990. Response of Hawaiian and other Indo-Pacific corals to elevated temperatures. Coral Reefs 8:155-162.

Jompa, J., and L.J. McCook. 2002. The effects of nutrients and herbivory on competition between a hard coral (Porites cylindrica) and a brown alga (Lobophora variegata). Limnol. Oceanogr. 47:527-534.

Jones, J.A. 1977. Morphology and development of southeastern Florida patch reefs. Proc. Third Int. Coral Reef Symp., Miami 2:231-235.

Jordán-Dahlgren, E. 1992. Recolonization patterns of Acropora palmata in a marginal environment. Bull. Mar. Sci. 51:104-117.

Kaufman, L. 1977. The three spot damselfish: Effects on benthic biota of Caribbean coral reefs. Proc. Third Int. Coral Reef Symp., Miami 1:559-564.

Keller, B.D., and A. Itkin. 2002. Shoreline nutrients and chlorophyll a in the Florida Keys, 1994-1997: A preliminary analysis. In The Everglades, Florida Bay, and Coral Reefs of the Florida Keys-An Ecosystem Sourcebook, eds. J.W. Porter and K.G. Porter, 649-658. Boca Raton: CRC Press.

Kerwin, M., J.T. Overpeck, R.S. Webb, A. DeVernal, D.H. Rind, and R.J. Healy. 1999. The role of oceanic forcing in mid-Holocene Northern Hemisphere climatic change. Paleoceanography 14:200-210.

Kidwell, S.M. 2001. Preservation of species abundance in marine death assemblages. Science 294:1091-1094.

Kindinger, J.L. 1986. Geomorphology and tidal-belt depositional model of lower Florida Keys. Am. Assoc. Petrol. Geol. Bull. 70:607. 
Kinsey, D.W. 1991. The coral reef: An owner-built, high-density, fully-serviced, selfsufficient housing estate in the desert—or is it? Symbiosis 10:1-22.

Kinzie, R.A., III. 1973. The zonation of West Indian gorgonians. Bull. Mar. Sci. 23: 93-155.

Kissling, D.L. 1977a. Coral reefs in the Lower Florida Keys: A preliminary report. In Field Guide to Some Carbonate Rock Environments_Florida Keys and Western Bahamas, ed. H.G. Multer, 209-215. Dubuque: Kendall/Hunt.

Kissling, D.L. 1977b. Population structure characteristics for some Paleozoic and modern colonial corals. In Second International Symposium on Corals and Fossil Coral Reefs, Paris, September 1975, 497-506. Paris: Memoires Du B.R.G.M. No. 89

Kleypas, J. 1997. Modeled estimates of global reef habitat and carbonate production since the last glacial maximum. Paleoceanography 12:533-545.

Kleypas, J.A., R.W. Buddemeier, D. Archer, J.-P. Gattuso, C. Langdon, and B.N. Opdyke. 1999. Geochemical consequences of increased atmospheric carbon dioxide on coral reefs. Science 284:118-120.

Kleypas, J.A., R.W. Buddemeier, and J.-P. Gattuso. 2001. The future of coral reefs in an age of global change. Geol. Rundsch. 90:426-437.

Kleypas, J.A., J. McManus, and L.B. Menez. 1999. Environmental limits to coral reef development: Where do we draw the line? Am. Zool. 39:146-159.

Knowlton, N. 1992. Thresholds and multiple stable states in coral reef community dynamics. Am. Zool. 32:674-682.

Knowlton, N. 2001. The future of coral reefs. Proc. Natl. Acad. Sci. USA 98:5419-5425.

Knowlton, N., J.C. Lang, and B.D. Keller. 1988. Fates of staghorn coral isolates on hurricane-damaged reefs in Jamaica: The role of predators. Proc. Sixth Int. Coral Reef Symp., Townsville 2:83-88.

Knowlton, N., J.C. Lang, and B.D. Keller. 1990. Case study of natural population collapse: Post-hurricane predation on Jamaican staghorn corals. Smithsonian Contrib. Mar. Sci. 31:1-25.

Knowlton, N., J.L. Maté, H.M. Guzmàn, R. Rowan, and J. Jara. 1997. Direct evidence for reproductive isolation among the three species of the Montastraea annularis complex in Central America (Panamá and Honduras). Mar. Biol. 127:705-711.

Knowlton, N., E. Weil, L.A. Weigt, and H.M. Guzmán. 1992. Sibling species in Montastraea annularis, coral bleaching, and the coral climate record. Science 255:330-333.

Kojis, B.L., and N.J. Quinn. 1994. Biological limits to Caribbean reef recovery: A comparison with western South Pacific reefs. In Proceedings of the Colloquium on Global Aspects of Coral Reefs: Health, Hazards and History, compiler R.N. Ginsburg, 353-359. Miami: Rosenstiel School of Marine and Atmospheric Science, University of Miami.

Kramer, P.R. (compiler). 2002. Report from the status and trends working group. In Proceedings of the Caribbean Acropora Workshop: Potential Application of the U.S. Endangered Species Act as a Conservation Strategy, ed. A. Bruckner, 28-37. NOAA-OPR-24.

Kramer, P.A., and P.R. Kramer. 2000. Ecological Status of the Mesoamerican Barrier Reef System: Impacts of Hurricane Mitch and 1998 Coral Bleaching. Final Report to the World Bank. Miami: Rosenstiel School of Marine and Atmospheric Science, University of Miami.

Kruczynski, W.L., and F. McManus. 2002. Water quality concerns in the Florida Keys: Sources, effects, and solutions. In The Everglades, Florida Bay, and Coral Reefs of the Florida Keys-An Ecosystem Sourcebook, eds. J.W. Porter and K.G. Porter, 827-881. Boca Raton: CRC Press. 
Kuta, K.G., and L.L. Richardson. 1996. Abundance and distribution of black band disease on coral reefs in the northern Florida Keys. Coral Reefs 15:219-223.

Landon, S.M. 1975. Environmental Controls on Growth Rates in Hermatypic Corals from the Lower Florida Keys. MS Thesis. Binghamton: SUNY.

Lang, J.C., H.R. Lasker, E.H. Gladfelter, P. Hallock, W.C. Jaap, F.J. Losada, and R.G. Muller. 1992. Spatial and temporal variability during periods of "recovery" after mass bleaching on western Atlantic coral reefs. Am. Zool. 32:696-706.

Lapointe, B.E. 1989. Caribbean coral reefs: Are they becoming algal reefs? Sea Front. 35:82-91.

Lapointe, B.E. 1997. Nutrient thresholds for bottom up control of marcroalgal blooms on coral reefs in Jamaica and southeast Florida. Limnol. Oceanogr. 42:1119-1131.

Lapointe, B.E. 1999. Simultaneous top-down and bottom-up forces control macroalgal blooms on coral reefs. Limnol. Oceanogr. 44:1586-1592.

Lapointe, B.E., P.J. Barile, and W.R. Matzie. 2004. Anthropogenic nutrient enrichment of seagrass and coral reef communities in the Lower Florida Keys: Discrimination of local versus regional nitrogen sources. J. Exp. Mar. Biol. Ecol. 308:23-58.

Lapointe, B.E., and M.W. Clark. 1992. Nutrient inputs from the watershed and coastal eutrophication in the Florida Keys. Estuaries 15:465.

Lapointe, B.E., M.M. Littler, and D.S. Littler. 1997. Macroalgal overgrowth of fringing coral reefs at Discovery Bay, Jamaica: Bottom-up versus top-down control. Proc. Eighth Int. Coral Reef Symp., Panama 1:927-932.

Lapointe, B.E., and W.R. Matzie. 1996. Effects of stormwater discharges on euthrophication processes in nearshore waters of the Florida Keys. Estuaries 19:422-435.

Lapointe, B.E., W.R. Matzie, and P.J. Barile. 2002. Biotic phase-shifts in Florida Bay and fore reef communities of the Florida Keys: Linkages with historical freshwater flows and nitrogen loading from Everglades runoff. In The Everglades, Florida Bay, and Coral Reefs of the Florida Keys-An Ecosystem Sourcebook, eds. J.W. Porter and K.G. Porter, 629-648. Boca Raton: CRC Press.

Lapointe, B.E., J.E. O'Connell, and G.S. Garrett. 1990. Nutrient couplings between on-site sewage disposal systems, groundwaters, and nearshore surface waters of the Florida Keys. Biogeochemistry 10:289-307.

Lapointe, B.E., and N.P. Smith. 1987. A preliminary investigation of upwelling as a source of nutrients to Looe Key National Marine Sanctuary. NOAA Technical Memorandum NOS MEMD 9. Washington, DC: NOAA.

Lee, T.N., E. Williams, E. Johns, D. Wilson, and N.P. Smith. 2002. Transport processes linking south Florida ecosystems. In The Everglades, Florida Bay, and Coral Reefs of the Florida Keys-An Ecosystem Sourcebook, eds. J.W. Porter and K.G. Porter, 309-342. Boca Raton: CRC Press.

Leichter, J.J., and S.L. Miller. 1999. Predicting high frequency upwelling: Spatial and temporal patterns of temperature anomalies on a Florida coral reef. Cont. Shelf Res. 19:911-928.

Leichter, J.J., H.L. Stewart, and S.L. Miller. 2003. Episodic nutrient transport to Florida coral reefs. Limnol. Oceanogr. 48:1394-1407.

Lessios, H.A. 1988. Mass mortality of Diadema antillarum in the Caribbean: What have we learned? Ann. Rev. Ecol. Syst. 19:371-393.

Lessios, H.A., D.R. Robertson, and J.D. Cubit. 1984. Spread of Diadema mass mortality through the Caribbean. Science 226:335-337.

Lewis, J.B. 1984. The Acropora inheritance: A reinterpretation of the development of fringing reefs in Barbados, West Indies. Coral Reefs 3:117-122. 
Lewis, S.M. 1986. The role of herbivorous fishes in the organization of a Caribbean reef community. Ecol. Monogr. 56:183-200.

Lidz, B.H. 1997. Fragile Coral Reefs of the Florida Keys: Preserving the Largest Reef Ecosystem in the Continental U.S. Open-File Report 97-453. St. Petersburg: US Geological Survey.

Lidz, B.H. 2000a. Bedrock Beneath Reefs: The Importance of Geology in Understanding Biological Decline in a Modern Ecosystem. Open-File Report 00-046. St. Petersburg: US Geological Survey.

Lidz, B.H. 2000b. Reefs, Corals, and Carbonate Sands: Guides to Reef Ecosystem Health and Environments. Open-File Report 00-164. St. Petersburg: US Geological Survey.

Lidz, B.H. 2004. Coral reef complexes at an atypical windward platform margin: Late Quaternary, southeast Florida. Geol. Soc. Am. Bull. 116:974-988.

Lidz, B.H., and P. Hallock. 2000. Sedimentary petrology of a declining reef ecosystem, Florida Reef Tract (USA). J. Coast. Res. 16:675-697.

Lidz, B.H., A.C. Hine, E.A. Shinn, and J.L. Kindinger. 1991. Multiple outer-reef tracts along the south Florida bank margin: Outlier reefs, a new windward-margin model. Geology 19:115-118.

Lidz, B.H., C.D. Reich, and E.A. Shinn. 2003. Regional Quaternary submarine geomorphology in the Florida Keys. Geol. Soc. Am. Bull. 115:845-866.

Lidz, B.H., D.M. Robbin, and E.A. Shinn. 1985. Holocene carbonate sedimentary petrology and facies accumulation, Looe Key National Marine Sanctuary, Florida. Bull. Mar. Sci. 36:672-700.

Lidz, B.H., and E.A. Shinn. 1991. Paleoshorelines, reefs, and a rising sea: South Florida, USA. J. Coast. Res. 7:203-229.

Lidz, B.H., E.A. Shinn, M.E. Hansen, R.B. Halley, M.W. Harris, S.D. Locker, and A.C. Hine. 1997a. Sedimentary and biological environments, depth to Pleistocene bedrock, and Holocene sediment and reef thickness, Key Largo, south Florida. US Geological Survey Miscellaneous Investigations Series, Map I-2505.

Lidz, B.H., E.A. Shinn, A.C. Hine, and S.D. Locker. 1997b. Contrasts within an outlierreef system: Evidence for differential Quaternary evolution, south Florida windward margin, USA. J. Coast. Res. 13:711-731.

Lighty, R.G. 1977. Relict shelf-edge Holocene coral reef, southeast coast of Florida. Proc. Third Int. Coral Reef Symp., Miami 2:215-221.

Lighty, R.G. 1981. Fleshy-algal domination of a modern Bahamian barrier reef: Example of an alternate climax reef community. Proc. Fourth Int. Coral Reef Symp., Manila 1:722.

Lighty, R.G., I.G. Macintyre, and A.C. Neumann. 1980. Demise of a Holocene barrier-reef complex, northern Bahamas. Geol. Soc. Am. Abstr. Prog. 12:471.

Lighty, R.G., I.G. Macintyre, and R. Stuckenrath. 1978. Submerged early Holocene barrier reef south-east Florida shelf. Nature 276:59-60.

Lighty, R.G., I.G. Macintyre, and R. Stuckenrath. 1982. Acropora palmata reef framework: A reliable indication of sea level in the western Atlantic for the past 10,000 years. Coral Reefs 1:125-130.

Lipp, E.K., J.L. Jarrell, D.W. Griffin, J. Jacukiewicz, J. Lukasik, and J.B. Rose. 2002. Preliminary evidence for human fecal contamination in corals of the Florida Keys, USA. Mar. Pollut. Bull. 44:666-670.

Lirman, D. 2000. Fragmentation in the branching coral Acropora palmata (Lamarck): Growth, survivorship, and reproduction of colonies and fragments. J. Exp. Mar. Biol. Ecol. 251:41-57. 
Lirman, D. 2001. Competition between macroalgae and corals: Effects of herbivore exclusion and increased algal biomass on coral survivorship and growth. Coral Reefs 19:392-399.

Lirman, D., and P. Fong. 1997. Patterns of damage to the branching coral Acropora palmata following Hurricane Andrew: Damage and survivorship of hurricanegenerated asexual recruits. J. Coast. Res. 13:67-72.

Littler, M.M., P.R. Taylor, D.S. Littler, R.H. Sims, and J.N. Norris. 1987. Dominant macrophyte standing stocks, productivity and community structure on a Belizean barrier reef. Atoll Res. Bull. 302:1-24.

Locker, S.D., A.C. Hine, L.P. Tedesco, and E.A. Shinn. 1996. Magnitude and timing of episodic sea-level rise during the last deglaciation. Geology 24:827-830.

Logan, A. 1988. Holocene Reefs of Bermuda, Sedimenta XI. Miami: Rosenstiel School of Marine and Atmospheric Science, University of Miami.

Lough, J.M. 2000. 1997-98: Unprecedented thermal stress to coral reefs? Geophys. Res. Lett. 23:3901-3904.

Ludwig, K.R., D.R. Muhs, K.R. Simmons, R.B. Halley, and E.A. Shinn. 1996. Sea-level records at $\sim 80 \mathrm{ka}$ from tectonically stable platforms: Florida and Bermuda. Geology 24:211-214.

Lugo, A.E., C. Rogers, and S. Nixon. 2000. Hurricanes, coral reefs and rainforests: Resistance, ruin and recovery in the Caribbean. Ambio 29:106-114.

Macintyre, I.G. 1988. Modern coral reefs of western Atlantic: New geological perspective. Am. Assoc. Petrol. Geol. Bull. 72:1360-1369.

Macintyre, I.G. 2006. Demise, regeneration, and survival of some western Atlantic reefs during the Holocene transgression. In Geological Approaches to Coral Reef Ecology, ed. R.B. Aronson, 181-200. New York: Springer-Verlag.

Macintyre, I.G., and P.G. Glynn. 1976. Evolution of a modern Caribbean fringing reef, Galeta Point, Panama. Am. Assoc. Petrol. Geol. Bull. 60:1054-1072.

Macintyre, I.G., and O.H. Pilkey. 1969. Tropical reef corals tolerance of low temperatures on the North Carolina continental shelf. Science 166:374-375.

Marsh, L.M. 1992. The occurrence and growth of Acropora in extra-tropical waters off Perth, Western Australia. Proc. Seventh Int. Coral Reef Symp., Guam 2:1233-1238.

Marszalek, D.S., G. Babashoff, M.R. Noel, and D.R. Worley. 1977. Reef distribution in south Florida. Proc. Third Int. Coral Reef Symp., Miami 2:223-229.

Matthews, R.K. 1986. Quaternary sea-level change. In Sea-Level Change-Studies in Geophysics, 88-103. Washington, DC: National Research Council.

Maul, G.A. 1992. Temperature and sea level change. In Global Warming: Physics and Facts, eds. B.G. Levi, D. Hafemeister, and R.A. Schribner, 78-112. New York: American Institute of Physics.

Mayer, A. 1902. The Tortugas as a station for research in biology. Science 17:190-192.

Mayer, A.G. 1914. The effects of temperature upon tropical marine animals. Papers Tortugas Laboratory, Carnegie Institute of Washington 6:1-14.

Mayer, A.G. 1915. The lower temperature at which reef corals lose their ability to capture food. Yearb. Carnegie Inst. Washington Publ. 183:1-24.

Mayer, A.G. 1918. Toxic effects due to high temperature. Papers Tortugas Laboratory, Carnegie Institute of Washington 252:172-178.

McClanahan, T.R., R.B. Aronson, W.F. Precht, and N.A. Muthiga. 1999. Fleshy algae dominate remote coral reefs of Belize. Coral Reefs 18:61-62.

McClanahan, T.R., and N.A. Muthiga. 1988. Changes in Kenyan coral reef community structure and function due to exploitation. Hydrobiologia 166:269-276. 
McClanahan, T.R., and N.A. Muthiga. 1998. An ecological shift among patch reefs of Glovers Reef Atoll, Belize over 25 years. Environ. Conserv. 25:122-130.

McClanahan, T.R., E. Sala, P.A. Stickels, B.A. Cokos, A.C. Baker, C.J. Stager, and S.H. Jones IV. 2003. Interaction between nutrients and herbivory in controlling algal communities and coral condition on Glover's Reef, Belize. Mar. Ecol. Prog. Ser. 261:135-147.

McCook, L.J. 2001. Competition between corals and algal turfs along a gradient of terrestrial influence in the nearshore central Great Barrier Reef. Coral Reefs 19:419-425.

McCook, L.J., J. Jompa, and G. Diaz-Pulido. 2001. Competition between corals and algae on coral reefs: A review of evidence and mechanisms. Coral Reefs 19:400-417.

McCook, L.J., E. Wolanski, and S. Spagnol. 2001. Modeling and visualizing interactions between natural disturbances and eutrophication as causes of coral reef degradation. In Oceanographic Processes of Coral Reefs: Physical and Biological Links in the Great Barrier Reef, ed. E. Wolanski, 113-125. Boca Raton: CRC Press.

McField, M.D. 1999. Coral response during and after mass bleaching in Belize. Bull. Mar. Sci. 64:155-172.

McManus, J.W., and J.F. Polsenberg. 2004. Coral-algal phase-shifts on coral reefs: Ecological and environmental aspects. Prog. Oceanogr. 60:263-279.

Mesolella, K.J. 1967. Zonation of uplifted Pleistocene coral reefs on Barbados, West Indies. Science 156:638-640.

Meyer, D.L., J.M. Bries, B.J. Greenstein, and A.O. Debrot. 2003. Preservation of in situ reef framework in regions of low hurricane frequency: Pleistocene of Curaçao and Bonaire, southern Caribbean. Lethaia 36:273-285.

Miller, M.W. 1998. Coral/seaweed competition and the control of reef community structure within and between latitudes. Oceanogr. Mar. Biol. Ann. Rev. 36:65-96.

Miller, M.W. 2001. Corallivorus snail removal: Evaluation of impact on Acropora palmata. Coral Reefs 19:293-295.

Miller, M.W. (compiler). 2002. Acropora corals in Florida: Status, trends, conservation, and prospects for recovery. In Proceedings of the Caribbean Acropora Workshop: Potential Application of the U.S. Endangered Species Act as a Conservation Strategy, ed. A. Bruckner, 59-70. NOAA-OPR-24.

Miller, M.W., I.B. Baums, D.E. Williams, and A.M. Szmant. 2002. Status of candidate coral, Acropora palmata, and its snail predator in the upper Florida Keys National Marine Sanctuary. NOAA Technical Memorandum NMFS-SEFSC-479.

Miller, M.W., A.S. Bourque, and J.A. Bohnsack. 2002. An analysis of the loss of acroporid corals at Looe Key, Florida, USA: 1983-2000. Coral Reefs 21:179-182.

Miller, M.W., M.E. Hay, S.L. Miller, D. Malone, E.E. Sotka, and A.M. Szmant. 1999. Effects of nutrients versus herbivores on reef algae: A new method for manipulating nutrients on coral reefs. Limnol. Oceanogr. 44:1847-1861.

Miller, M.W., E. Weil, and A.M. Szmant. 2000. Coral recruitment and juvenile mortality as structuring factors for reef benthic communities in Biscayne National Park, USA. Coral Reefs 19:115-123.

Miller, S.L., and M.P. Crosby. 1999. The extent and condition of U.S. coral reefs. In NOAA's State of the Coast Report, 1-34. Silver Spring: NOAA.

Miller, S.L., and D.W. Swanson. 1999. Rapid assessment methods for monitoring marine protected areas in the Florida Keys National Marine Sanctuary: Program design and effects of Hurricane Georges on reefs in the middle and lower Keys. In Abstracts with Program, International Conference on Scientific Aspects of Coral Reef Assessment, Monitoring, and Restoration, 139-140. Ft. Lauderdale: NCRI. 
Miller, S.L., D.W. Swanson, and M. Chiappone. 2002. Multiple spatial scale assessment of coral reef and hard-bottom community structure in the Florida Keys National Marine Sanctuary. Proc. Ninth Int. Coral Reef Symp. Bali 1:69-74.

Mitterer, R.M. 1974. Pleistocene stratigraphy in southern Florida based on amino acid diagenesis in fossil Mercenaria. Geology 2:425-428.

Muhs, D.R., B.J. Szabo, L. McCartan, P.B. Maat, C.A. Bush, and R.B. Halley. 1992. Uranium-series estimates of corals from Quaternary marine sediments of southern Florida. In The Plio-Pleistocene Stratigraphy and Paleontology of Southern Florida, eds. T.M. Scott and W.D. Allmon. Florida Geological Survey Special Publication 36:41-49.

Muller-Karger, F.E., C.R. McClain, T.R. Fisher, W.E. Esaias, and R. Varela. 1989. Pigment distribution in the Caribbean Sea: Observations from space. Prog. Oceanogr. 23:23-64.

Multer, H.G. 1977. Pleistocene back reef environments. In Field Guide to Some Carbonate Rock Environments-Florida Keys and Western Bahamas, ed. H.G. Multer, 258-271. Dubuque: Kendall/Hunt.

Multer, H.G., E. Gischler, J. Lundberg, K.R. Simmons, and E.A. Shinn. 2002a. Key Largo Limestone revisited: Pleistocene shelf-edge facies, Florida Keys, USA. Facies 46:229-272.

Multer, H.G., E. Gischler, J. Lundberg, K.R. Simmons, and E.A. Shinn. 2002b. Key Largo Limestone revisited: Pleistocene shelf-edge facies, Florida Keys, USA. Geol. Soc. Am. Abstr. Progr. 34:388.

Multer, H.G. and J.E. Hoffmeister. 1977. Petrology and significance of the Key Largo (pleistocene) Limestone. In Field Guide to Some Carbonate Rock EnvironmentsFlorida Keys and Western Bahamas, ed. H.G. Multer, 261-264. Dubuque: Kendall/Hunt.

Murdoch, T.J.T., and R.B. Aronson. 1999. Scale-dependent spatial variability of coral assemblages along the Florida reef tract. Coral Reefs 18:341-351.

Nagelkerken, I.K., C.D. Harvell, C. Heberer, K. Kim, C. Petrovic, L. Pors, and P. Yoshioka. 1997. Wide-spread disease in Caribbean sea fans: II. Patterns of infection and tissue loss. Mar. Ecol. Prog. Ser. 160:255-263.

National Research Council. 1988. Toward an Understanding of Global Change. Washington, DC: National Academy Press.

Neumann, A.C., and P.J. Hearty. 1996. Rapid sea-level changes at the close of the last interglacial (stage 5e) recorded in Bahamian Island geology. Geology 24:775-778.

Neumann, A.C., and I.G. Macintyre. 1985. Reef response to sea level rise: Keep-up, catchup or give-up. Proc. Fifth Int. Coral Reef Congr., Tahiti 3:105-110.

Neumann, C.J., B.R. Jarvinen, C.J. McAdie, and J.D. Elms. 1993. Tropical Cyclones of the North Atlantic Ocean, 1871-1992. Asheville: NOAA National Climatic Data Center.

Newell, N.D., J. Imbrie, E.G. Purdy, and D.L. Thurber. 1959. Organism communities and bottom facies, Great Bahamas Bank. Am. Mus. Nat. Hist. Bull. 117:181-228.

NOAA (National Oceanic and Atmospheric Administration). 2003. The Florida Keys: A progression in protection. www.noaanews.noaa.gov/magazine/stories/mag92.htm.

Nyström, M., C. Folke, and F. Moberg. 2000. Coral reef disturbance and resilience in a human-dominated environment. Trends Ecol. Evol. 15:413-417.

Ogden, J.C., J.W. Porter, N.P. Smith, A.M. Szmant, W.C. Jaap, and D. Forcucci. 1994. A long-term interdisciplinary study of the Florida Keys seascape. Bull. Mar. Sci. 54:1059-1071.

Osmund, J.K., J.R. Carpenter, and H.L. Windom. 1964. Th ${ }^{230} / \mathrm{U}^{234}$ age of Pleistocene corals and oolites of Florida. J. Geophys. Res. 70:1843-1847. 
Ostrander, G.K., K.M. Armstrong, E.T. Knobbe, D. Gerace, and E.P. Scully. 2000. Rapid transition in the structure of a coral reef community: The effects of coral bleaching and physical disturbance. Proc. Natl. Acad. Sci. USA 97:5297-5302.

Pandolfi, J.M. 1999. Response of Pleistocene coral reefs to environmental change over long temporal scales. Am. Zool. 39:113-130.

Pandolfi, J.M. 2001. Pleistocene persistence and the recent decline in Caribbean coral communities. PaleoBios 21:100.

Pandolfi, J.M. 2002. Coral community dynamics at multiple scales. Coral Reefs 21:13-23.

Pandolfi, J.M., R.H. Bradbury, E. Sala, T.P. Hughes, K.A. Bjorndal, R.G. Cooke, D. McArdle, L. McClenachan, M.J.H. Newman, G. Paredes, R.R. Warner, and J.B.C. Jackson. 2003. Global trajectories of the long-term decline of coral reef ecosystems. Science 301:955-958.

Pandolfi, J.M., and J.B.C. Jackson. 1997. The maintenance of diversity on coral reefs: Examples from the fossil record. Proc. Eighth Int. Coral Reef Symp., Panama 1:397-404.

Pandolfi, J., and J.B.C. Jackson. 2001. Community structure of Pleistocene coral reefs of Curaçao, Netherlands Antilles. Ecol. Monogr. 71:49-67.

Pasley, D. 1972. Field Guide - Field Trip \#1, Windley Key Quarry (Key Largo Limestone). Miami: American Quaternary Association Second National Conference.

Patterson, K.L., J.W. Porter, K.B. Ritchie, S.W. Polson, E. Mueller, E.C. Peters, D.L. Santavy, and G.W. Smith. 2002. The etiology of white pox, a lethal disease of the Caribbean elkhorn coral, Acropora palmata. Proc. Natl. Acad. Sci. USA 99:8725-8730.

Paul, J.H., J.B. Rose, J.K. Brown, E.A. Shinn, S. Miller, and S.R. Farrah. 1995. Viral tracer studies indicate contamination of marine waters by sewage disposal practices in Key Largo, FL. Appl. Environ. Microbiol. 61:2230-2234.

Paul, J.H., J.B. Rose, S.C. Jiang, X. Zhou, P. Cochran, C.A. Kellog, J.B. Kang, D.W. Griffin, S.R. Farrah, and J. Lulasik. 1997. Evidence for groundwater and surface marine water contamination by waste disposal wells in the Florida Keys. Water Res. 32:1448-1454.

Paulay, G. 1990. Effects of late Cenozoic sea-level fluctuations on the bivalve faunas of tropical oceanic islands. Paleobiology 16:415-434.

Pauly, D.W., J. Christiansen, J. Dahsgaard, R. Froese, and F.C. Torres, Jr. 1998. Fishing down marine food webs. Science 279:860-863.

Pennisi, E. 1997. Brighter prospects for the world's coral reefs? Science 277:491-493.

Perkins, R.D. 1977. Depositional framework of Pleistocene rocks in south Florida. In Quaternary Sedimentation in South Florida, Memoir 147, eds. P. Enos and R.D. Perkins, 131-198. Boulder: Geological Society of America.

Perkins, R.D., and P. Enos. 1968. Hurricane Betsy in the Florida-Bahama area-Geologic effects and comparison with Hurricane Donna. J. Geol. 76:710-717.

Peters, E.C. 1997. Diseases of coral reef organisms. In Life and Death of Coral Reefs, ed. C. Birkeland, 114-139. New York: Chapman and Hall.

Peters, E.C., and H.B. McCarty. 1996. Carbonate crisis? Geotimes 41:20-23.

Peters, E.C., P.P. Yevich, and J.J. Oprandy. 1983. Possible causal agent of 'white band disease' in Caribbean acroporid corals. J. Invertebr. Pathol. 41:394-396.

Pielou, E.C. 1991. After the Ice Age. Chicago: University of Chicago Press.

Pitts, P.A. 2002. The role of advection in transporting nutrients to the Florida reef tract. Proc. Ninth Int. Coral Reef Symp., Bali 2:1219-1224.

Playford, P.E. 1988. Guidebook of the geology of Rottnest Island. Geological Society of Australia. 
Podestá, G.P., and P.W. Glynn. 1997. Sea surface temperature variability in Panamá and Gálapagos: Extreme temperatures causing coral bleaching. J. Geophys. Res. 102:15749-15759.

Podestá, G.P., and P.W. Glynn. 2001. The 1997-98 El Niño event in Panamá and Galápagos: An update of thermal stress indices relative to coral bleaching. Bull. Mar. Sci. 69:43-59.

Porter, J.W., J.F. Battey, and J.G. Smith. 1982. Perturbation and change in coral reef communities. Proc. Natl. Acad. Sci. USA 79:1678-1681.

Porter, J.W., P. Dustan, W.C. Jaap, K.L. Patterson, V. Kosmynin, O.W. Meier, M.E. Patterson, and M. Parsons. 2001. Patterns of spread of coral diseases in the Florida Keys. Hydrobiologia 460:1-24.

Porter, J.W., W.K. Fitt, H.J. Spero, C.S. Rogers, and M.W. White. 1989. Bleaching in reef corals: Physiological and stable isotopic responses. Proc. Natl. Acad. Sci. USA 86:9342-9346.

Porter, J.W., V. Kosmynin, K.L. Patterson, K.G. Porter, et al. 2002. Detection of coral reef change by the Florida Keys Coral Reef Monitoring Project. In The Everglades, Florida Bay, and Coral Reefs of the Florida Keys; An Ecosystem Sourcebook, eds. J.W. Porter and K.G. Porter, 749-769. Boca Raton: CRC Press.

Porter, J.W., S.K. Lewis, and K.G. Porter. 1999. The effect of multiple stressors on the Florida Keys coral reef ecosystem: A landscape hypothesis and a physiological test. Limnol. Oceanogr. 44:941-949.

Porter, J.W., and O.W. Meier. 1992. Quantification of loss and change in Floridian reef coral populations. Am. Zool. 32:625-640.

Porter, J.W., and J.I. Tougas. 2001. Reef ecosystems: Threats to their biodiversity. In Encyclopedia of Biodiversity, Vol. 5, 73-95. New York: Academic Press.

Porter, J.W., J.D. Woodley, G.J. Smith, J.E. Neigel, J.F. Battey, and D.F. Dallmeyer. 1981. Population trends among Jamaican reef corals. Nature 294:249-250.

Precht, W.F. 1993. Stratigraphic evidence from reef studies for a double-high sea stand during the last interglacial maximum. Am. Assoc. Petrol. Geol. Bull. 77:1473.

Precht, W.F. (ed.). 2006. Reef Restoration Handbook-The Rehabilitation of an Ecosystem Under Siege. Boca Raton: CRC Press.

Precht, W.F., and R.B. Aronson. 1997. White band disease in the Florida Keys-A continuing concern. Reef Encounter 22:14-16.

Precht, W.F., and R.B. Aronson. 2002. The demise of Acropora in the Caribbean: A tale of two reef systems. In Proceedings of the Caribbean Acropora Workshop: Potential Application of the U.S. Endangered Species Act as a Conservation Strategy, ed. A. Bruckner, 147. NOAA-OPR-24.

Precht, W.F., and R.B. Aronson. 2004. Climate flickers and range shifts of reef corals. Front. Ecol. Environ. 6:307-313.

Precht, W.F., and R.B. Aronson. 2006. Death and resurrection of Caribbean reefs: A palaeoecological perspective. In Coral Reef Conservation, eds. I. Côté and J. Reynolds, 40-77. Cambridge: Cambridge University Press.

Precht, W.F., R.B. Aronson, P.J. Edmunds, and D.R. Levitan. 1993. Hurricane Andrew's effect on the Florida reef tract. Am. Assoc. Petrol. Geol. Bull. 77:1473.

Precht, W.F., R.B. Aronson, S.L. Miller, B.D. Keller, and B. Causey. 2005a. The folly of coral restoration programs following natural disturbances in the Florida Keys National Marine Sanctuary. Ecol. Restor. 23:24-28.

Precht, W.F., A.W. Bruckner, R.B. Aronson, and R.J. Bruckner. 2002. Endangered acroporid corals of the Caribbean. Coral Reefs 21:41-42. 
Precht, W.F., and W.H. Hoyt. 1991. Reef facies distribution patterns, Pleistocene (125 Ka) Falmouth Formation, Rio Bueno, Jamaica, WI. Am. Assoc. Petrol. Geol. Bull. 75:656-657.

Precht, W.F., I.G. Macintyre, R.E. Dodge, K. Banks, and L. Fisher. 2000. Backstepping of Holocene reefs along Florida's east coast. Abstr. Prog., Ninth Int. Coral Reef Symp., Bali 321.

Precht, W.F., S.L. Miller, R.B. Aronson, J.F. Bruno, and L. Kaufman. 2005b. Reassessing U.S. coral reefs. Science 308:1741.

Randazzo, A.F., and R.B. Halley. 1997. Geology of the Florida Keys. In The Geology of Florida, eds. A.F. Randazzo and D.S. Jones, 251-259. Gainesville: University Press of Florida.

Raymond, W.F. 1972. A geologic investigation of the offshore sands and reefs of Broward County, Florida. MS Thesis. Tallahassee: Florida State University.

Reich, C.D., E.A. Shinn, T.D. Hickey, and A.B. Tihansky. 2002. Tidal and meteorological influences on shallow marine groundwater flow in the upper Florida Keys. In The Everglades, Florida Bay, and Coral Reefs of the Florida Keys-An Ecosystem Sourcebook, eds. J.W. Porter and K.G. Porter, 827-881. Boca Raton: CRC Press.

Richardson, L.L. 1998. Coral diseases: What is really known? Trends Ecol. Evol. 13:438-443.

Richardson, L.L., and R.B. Aronson. 2002. Infectious diseases of reef corals. Proc. Ninth Int. Coral Reef Symp., Bali 2:1225-1230.

Richardson, L.L., W.M. Goldberg, K.G. Kuta, R.B. Aronson, G.W. Smith, K.B. Richie, J.C. Halas, J.S. Feingold, and S.L. Miller. 1998. Florida's mystery coral-killer identified. Nature 393:557-558.

Risk, M.J. 1999. Paradise lost: How marine science failed the world's coral reefs. Mar. Freshwater Res. 50:831-837.

Risk, M.J., J.M. Heikoop, E.N. Edinger, and M.V. Erdmann. 2001. The assessment 'toolbox': Community-based reef evaluation methods coupled with geochemical techniques to identify sources of stress. Bull. Mar. Sci. 69:443-458.

Ritchie, K.B., and G.W. Smith. 1998. Type II white-band disease. Rev. Biol. Trop. 46:199-203.

Roberts, C.M. 1995. Effects of fishing on the ecosystem structure of coral reefs. Conserv. Biol. 9:988-995.

Roberts, C.M. 1997. Connectivity and management of Caribbean coral reefs. Science 278:1454-1457.

Roberts, H.H., L.J. Rouse, Jr., and N.D. Walker. 1983. Evolution of cold-water stress conditions in high-latitude reef systems: Florida Reef Tract and the Bahama Banks. Caribb. J. Sci. 19:55-60.

Roberts, H.H., L.J. Rouse, Jr., N.D. Walker, and J.H. Hudson. 1982. Cold-water stress in Florida Bay and northern Bahamas: A product of winter cold-air outbreaks. $J$. Sediment. Petrol. 52:145-155.

Roberts, H.H., P.A. Wilson, and A. Lugo-Fernandez. 1992. Biologic and geologic responses to physical processes: Examples from modern reef systems of the CaribbeanAtlantic region. Cont. Shelf Res. 12:809-834.

Robinson, A. 1973. Natural vs. visitor-related damage to shallow water corals: Recommendations for visitor management and the design of underwater nature trails in the Virgin Islands. National Park Service Report, 1-23.

Rogers, C.S. 1983. Sublethal and lethal effects of sediments applied to common Caribbean reef corals in the field. Mar. Pollut. Bull. 14:378-382.

Rogers, C.S. 1985. Degradation of Caribbean and western Atlantic coral reefs and decline of associated fisheries. Proc. Fifth Int. Coral Reef Congr., Tahiti 6:491-496. 
Rogers, C.S. 1990. Responses of coral reefs and reef organisms to sedimentation. Mar. Ecol. Prog. Ser. 62:185-202.

Rogers, C.S. 1993a. Hurricanes and coral reefs: The intermediate disturbance hypothesis revisited. Coral Reefs 12:127-137.

Rogers, C.S. 1993b. A matter of scale: Damage from Hurricane Hugo (1989) to U.S. Virgin Islands reefs at the colony, community, and whole reef level. Proc. Seventh Int. Coral Reef Symp., Guam 1:127-133.

Rogers, C.S., and J. Beets. 2001. Degradation of marine ecosystems and decline of fishery resources in marine protected areas in the US Virgin Islands. Environ. Conserv. 28:312-322.

Rogers, C.S., H.C. Fitz III, M. Gilnack, J. Beets, and J. Hardin. 1984. Scleractinian coral recruitment patterns at Salt River Submarine Canyon, St. Croix, U.S. Virgin Islands. Coral Reefs 3:69-76.

Rogers, C., W. Gladfelter, D. Hubbard, E. Gladfelter, J. Bythell, R. Dunsmore, C. Loomis, B. Devine, Z. Hillis-Starr, and B. Phillips. 2002. Acropora in the US Virgin Islands: A wake or an awakening? In Proceedings of the Caribbean Acropora Workshop: Potential Application of the U.S. Endangered Species Act as a Conservation Strategy, ed. A. Bruckner, 95-118. NOAA-OPR-24.

Rosenberg, E., and Y. Ben-Haim. 2002. Microbial diseases of corals and global warming. Environ. Microbiol. 4:318-326.

Rosesmyth, M.C. 1984. Growth and survival of sexually produced Acropora recruits: A post-hurricane study at Discovery Bay. In Advances in Reef Science, eds. P.W. Glynn, P.K. Swart, and A.M. Szmant-Froelich, 105-106. Miami: Rosenstiel School of Marine and Atmospheric Science, University of Miami.

Roy, K., J.W. Valentine, D. Jablonski, and S.M. Kidwell. 1996. Scales of climatic variability and time averaging in Pleistocene biotas: Implications for ecology and evolution. Trends Ecol. Evol. 11:458-463.

Ruddiman, W.F., and A.C. Mix. 1991. The north and equatorial Atlantic at 9000 and 6000 yr B.P. In Global Climates Since the Last Glacial Maximum, eds. H.E. Wright, Jr., J.E. Kutzbach, T. Webb III, W.F. Ruddiman, F.A. Street-Perrott, and P.J. Bartlein, 94-124. Minneapolis: University of Minnesota Press.

Rützler, K., and I.G. Macintyre. 1982. The habitat distribution and community structure of the barrier reef complex at Carrie Bow Cay, Belize. In The Atlantic Barrier Reef Ecosystem at Carrie Bow Cay, Belize, I. Structure and Communities, eds. K. Rützler and I.G. Macintyre, 9-45. Washington, DC: Smithsonian Institution Press.

Rylaarsdam, K.W. 1983. Life histories and abundance patterns of colonial corals on Jamaican reefs. Mar. Ecol. Prog. Ser. 13:249-260.

Salvigsen, O., S.L. Forman. and G.H. Miller. 1992. Thermophilous molluscs on Svalbard during the Holocene and their paleoclimatic implications. Polar Res. 11:110.

Sammarco, P.W., M.J. Risk, H.P. Schwarcz, and J.M. Heikoop. 1999. Cross-continental shelf trends in $\delta^{15} \mathrm{~N}$ on the Great Barrier Reef: Further consideration of the reef nutrient paradox. Mar. Ecol. Prog. Ser. 180:131-138.

Sanford, S. 1909. The topography and geology of southern Florida. Florida Geological Survey Second Annual Report, 175-231.

Santavy, D.L., E. Mueller, E.C. Peters, L. MacLaughlin, J.W. Porter, K.L. Patterson, and J. Campbell. 2001. Quantitative assessment of coral diseases in the Florida Keys: Strategy and methodology. Hydrobiologia 460:39-52.

Santavy, D.L., and E.C. Peters. 1997. Microbial pests: Coral diseases in the western Atlantic. Proc. Eighth Int. Coral Reef Symp., Panama 1:607-612. 
Santavy, D.L., E.C. Peters, C. Quirolo, J.W. Porter, and C.N. Bianchi. 1999. Yellow-blotch disease outbreak on reefs of the San Blas Islands, Panama. Coral Reefs 19:97.

Sheppard, C. 1993. Coral reef environmental science: Dichotomies, not the Cassandras, are false. Reef Encounter 14:12-13.

Sheppard, C.R.C. 2003. Predicted recurrences of mass coral mortality in the Indian Ocean. Nature 425:294-297.

Shinn, E.A. 1963. Spur and groove formation on the Florida reef tract. J. Sediment. Petrol. 33:291-303.

Shinn, E.A. 1966. Coral growth rate, an environmental indicator. J. Paleontol. 40:233-240.

Shinn, E.A. 1976. Coral reef recovery in Florida and the Persian Gulf. Environ. Geol. $1: 241-254$.

Shinn, E.A. 1980. Geologic history of Grecian Rocks, Key Largo Coral Reef Marine Sanctuary. Bull. Mar. Sci. 30:646-656.

Shinn, E.A. 1984. Geologic history, sediment and geomorphic variations within the Florida reef tract. In Advances in Reef Science, 113-114. Miami: Rosenstiel School of Marine and Atmospheric Science, University of Miami.

Shinn, E.A. 1988. The geology of the Florida Keys. Oceanus 31:46-53.

Shinn, E.A. 1989. What is really killing the corals? Sea Front. 35:72-81.

Shinn, E.A. 1996. No rocks, no water, no ecosystem. Geotimes 41:16-19.

Shinn, E.A. 2001. African dust causes widespread environmental distress. St. Petersburg: US Geological Survey Open-File Report 01-246.

Shinn, E.A., J.H. Hudson, R.B. Halley, and B.H. Lidz. 1977. Topographic control and accumulation rate of some Holocene coral reefs, south Florida and Dry Tortugas. Proc. Third Int. Coral Reef Symp., Miami 2:1-7.

Shinn, E.A., J.H. Hudson, D.M. Robbin, and B.H. Lidz. 1981. Spurs and grooves revisited: Construction versus erosion, Looe Key Reef, Florida. Proc. Fourth Int. Coral Reef Symp., Manila 1:475-483.

Shinn, E.A., B.H. Lidz, and M.W. Harris. 1994. Factors controlling distribution of Florida Keys reefs. Bull. Mar. Sci. 54:1084.

Shinn, E.A., B.H. Lidz, J.L. Kindinger, J.H. Hudson, and R.B. Halley. 1989. Reefs of Florida and the Dry Tortugas. Field Trip Guidebook T176. Washington, DC: American Geophysical Union.

Shinn, E.A., R.S. Reese, and C.D. Reich. 1994. Fate and Pathways of Injection-Well Effluent in the Florida Keys. St. Petersburg: US Geological Survey Open-File Report 94-276.

Shinn, E.A., C.D. Reich, and T.D. Hickey. 2002. Seepage meters and Bernoulli's revenge. Estuaries 25:126-132.

Shinn, E.A., C.D. Reich, T.D. Hickey, and B.H. Lidz. 2003. Staghorn tempestites in the Florida Keys. Coral Reefs 22:91-97.

Shinn, E.A., G.W. Smith, J.M. Prospero, P. Betzer, M.L. Hayes, V. Garrison, and R.T. Barber. 2000. African dust and the demise of Caribbean coral reefs. Geophys. Res. Lett. 27:3029-3032.

Smith, J.E., C.M. Smith, P.S. Vroom, K.L. Beach, and S. Miller. 2004. Nutrient and growth dynamics of Halimeda tuna on Conch Reef, Florida Keys: Possible influence of internal tides on nutrient status and physiology. Limnol. Oceanogr. 49: 1923-1936.

Smith, N.P. 1994. Long-term Gulf-to-Atlantic transport trough tidal channels in the Florida Keys. Bull. Mar. Sci. 54:602-609. 
Smith, N.P., and P.A. Pitts. 2002. Regional-scale and long-term transport processes in the Florida Keys. In The Everglades, Florida Bay, and Coral Reefs of the Florida KeysAn Ecosystem Sourcebook, eds. J.W. Porter and K.G. Porter, 343-360. Boca Raton: CRC Press.

Smith, S.R., G. Webster, S. De Putron, T. Murdoch, S. McKenna, D. Hellin, L. Grayston, and A.M. Stanley. 2002. Coral population dynamics on Bermuda's reefs: A key to understanding reef development and persistence at high latitude. ISRS European Meeting Abstracts Volume, 91. Cambridge: International Society for Reef Studies.

Smith, S.V., and R.W. Buddemeier. 1992. Global change and coral reef ecosystems. Ann. Rev. Ecol. Syst. 23:89-118.

South-West Florida Dark-Water Observations Group. 2002. Satellite images track "black water" event off Florida coast. Eos 83: 281, 285.

Stachowicz, J., H. Fried, R.W. Osman, and R.B. Whitlatch. 2002. Biodiversity, invasion resistance, and marine ecosystem function: Reconciling pattern and process. Ecology 83:2575-2590.

Stanley, S.M. 1966. Paleoecology and diagenesis of Key Largo Limestone, Florida. Am. Assoc. Petrol. Geol. Bull. 50:1927-1947.

Stemann, T.A., and K.G. Johnson. 1992. Coral assemblages, biofacies, and ecological zones in the mid-Holocene reef deposits of the Enriquillo Valley, Dominican Republic. Lethaia 25:231-241.

Steneck, R.S. 1994. Is herbivore loss more damaging to reefs than hurricanes? Case studies from two Caribbean reef systems. In Proceedings of the Colloquium on Global Aspects of Coral Reefs: Health, Hazards and History, compiler R.N. Ginsburg, 220-226. Miami: Rosenstiel School of Marine and Atmospheric Science, University of Miami.

Steneck, R.S. 1998. Human influences on coastal ecosystems: Does overfishing create trophic cascades? Trends Ecol. Evol. 13:429-430.

Stober, Q.J., K. Thornton, R. Jones, J. Richards, C. Ivey, R. Welch, M. Madden, J. Trexler, E. Gaiser, D. Scheidt, and S. Rathbun. 2001. South Florida Ecosystem AssessmentPhase I/II-Everglades stressor interactions: Hydropatterns, euthrophication, habitat alteration, and mercury contamination. Monitoring for adaptive management: Implications for ecosystem restoration. United States Environmental Protection Agency, EPA 904-R-01-002.

Stoddart, D.R. 1963. Effects of Hurricane Hattie on the British Honduras reefs and cays, October 30-31, 1961. Atoll Res. Bull. 95:1-142.

Stoddart, R., and T.P. Scoffin. 1979. Microatolls: Review of form, origin and terminology. Atoll Res. Bull. 224:1-17.

Stokstad, E. 2001. Humans to blame for coral loss. Science 293:593.

Stone, L., A. Huppert, B. Rajagopalan, H. Bhasin, and Y. Loya. 1999. Mass coral reef bleaching: A recent outcome of increased El-Niño activity? Ecol. Lett. 2:325-330.

Strasser, M. 1999. Mya arenaria-An ancient invader of the North Sea coast. Helgol. Wiss. Meeresunters. 52:309-324.

Swart, P.K., A. Saied, and K. Lamb. 2005. Temporal and spatial variation in the $\delta^{15} \mathrm{~N}$ and $\delta^{13} \mathrm{C}$ of coral tissue and zooxanthellae in Montastraea faveolata collected from the Florida reef tract. Limnol. Oceangr. 50:1049-1058.

Szabo, B.J. 1979. Uranium-series age of coral reef growth on Rottnest Island, Western Australia. Mar. Geol. 29:M11-M15. 
Szmant, A.M. 1997. Nutrient effects on coral reefs: A hypothesis on the importance of topographic and trophic complexity to reef nutrient dynamics. Proc. Eighth Int. Coral Reef Symp., Panama 2:1527-1532.

Szmant, A.M. 2002. Nutrient enrichment on coral reefs: Is it a major cause of coral reef decline? Estuaries 25:743-766.

Szmant, A.M., and A. Forrester. 1996. Water column and sediment nitrogen and phosphorus distribution patterns in the Florida Keys, USA. Coral Reefs 15:21-41.

Taira, K. 1979. Holocene migrations of the warm-water front and sea-level fluctuations in the northwestern Pacific. Palaeogeogr. Palaeoclimatol. Palaeoecol. 28:197-204.

Taylor, J.F., and C.H. Saloman. 1968. Some effects of hydraulic dredging and coastal development in Boca Ciega Bay, Florida. US Fish Wildl. Serv. 67:213-241.

Textoris, S.D., J.M. Fuhr, and D.F. Merriam. 1989. Patch reefs in the Pleistocene of south Florida and their implications. Geol. Soc. Am. Abstr. Progr. 21:41.

Thompson, L.G., M.E. Davis, E. Mosley-Thompson, T.A. Sowers, K.A. Henderson, V.S. Zagorodnov, P.-N. Lin, V.N. Mikhalenko, R.K. Campen, J.F. Bolzan, J. Cole-Dai, and B. Francou. 1998. A 25,000-year tropical climate history from Bolivian ice cores. Science 282:1858-1864.

Tomascik, T., and F. Sander. 1987. Effects of eutrophication on reef-building corals. II. Structure of scleractinian coral communities on fringing reefs, Barbados, West Indies. Mar. Biol. 94:53-75.

Torrance, D.C. 1991. Deep ecology: Rescuing Florida's coral reefs. Nature Conservancy 4:9-17.

Toscano, M.A., and J. Lundberg. 1998. Early Holocene sea-level record from submerged fossil reefs on the southeast Florida margin. Geology 26:255-258.

Toscano, M.A., and J. Lundberg. 1999. Submerged Late Pleistocene reefs on the tectonically-stable S.E. Florida margin: High-precision geochronology, stratigraphy, resolution of Substage 5a sea-level elevation, and orbital forcing. Quat. Sci. Rev. 18:753-767.

Toscano, M.A., and I.G. Macintyre. 2000. Response of southeast Florida and Bahamas Holocene relict reefs to deglacial sea-level rise. Abstr. Progr., Ninth Int. Coral Reef Symp., Bali 59.

Toscano, M.A., and I.G. Macintyre. 2003. Corrected western Atlantic sea-level curve for the last 11,000 years based on calibrated ${ }^{14} \mathrm{C}$ dates from Acropora palmata and mangrove intertidal peat. Coral Reefs 22:257-270.

Treml, E., M. Colgan, and M. Keevican. 1997. Hurricane disturbance and coral reef development: A geographic information system (GIS) analysis of 501 years of hurricane data from the Lesser Antilles. Proc. Eighth Int. Coral Reef Symp., Panama 1:541-546.

Trend-Staid, M., and W.L. Prell. 2002. Sea surface temperature at the Last Glacial Maximum: A reconstruction using the modern analog technique. Paleoceanography 17:1065-1083.

Tunnicliffe, V. 1981. Breakage and propagation of the stony coral Acropora cervicornis. Proc. Natl. Acad. Sci. USA 78:2427-2431.

Tunnicliffe, V. 1983. Caribbean staghorn coral populations-Pre-Hurricane Allen conditions in Discovery Bay, Jamaica. Bull. Mar. Sci. 33:132-151.

Vargas-Ángel, B., J.D. Thomas, and S.M. Hoke. 2003. High-latitude Acropora cervicornis thickets off Fort Lauderdale, Florida, USA. Coral Reefs 22:465-474.

Vaughan, T.W. 1914. Investigations of the geology and geologic processes of the reef tracts and adjacent areas of the Bahamas and Florida. Carnegie Inst. Washington Yearb. 12:1-183. 
Vaughan, T.W. 1918. The temperature of the Florida coral reef tract. Carnegie Inst. Washington Publ. 213:321-339.

Vaughan, T.W. 1919a. Fossil corals from Central America, Cuba, and Puerto Rico, with an account of the American Tertiary, Pleistocene and Recent coral reefs. US Natl. Mus. Bull. 103:189-524.

Vaughan, T.W. 1919b. Corals and the formation of coral reefs. Smithsonian Inst. Ann. Rep.-1917, 189-238.

Veron, J.E.N. 1992. Environmental control of Holocene changes to the world's most northern hermatypic coral outcrop. Pac. Sci. 46:405-425.

Vitousek, P.M., J. Aber, R.W. Howarth, G.E. Likens, P.A. Matson, D.W. Schindler, W.H. Schlesinger, and D.G. Tilman. 1997. Human alteration of the global nitrogen cycle: Sources and consequences. Ecol. Appl. 7:737-750.

Vollmer, S.V., and S.R. Palumbi. 2002. Hybridization and the evolution of reef coral diversity. Science 296:2023-2025.

Voss, G.L. 1960. First underseas park. Sea Front. 6:87-94.

Voss, G.L. 1973. Sickness and health in Florida's coral reefs. Nat. Hist. 82:40-47.

Voss, G.L. 2002. An environmental assessment of the John Pennekamp Coral Reef State Park and the Key Largo Coral Reef Marine Sanctuary (Unpublished 1983 Report). In NOAA Technical Memorandum NOS NCCOS CCMA 161, eds. N. Voss, A.Y. Cantillo, and M.J. Bello. Joint NOAA/UMiami report. NOAA LISD Current References 2002-6. University of Miami RSMAS TR 2002-03.

Walker, N.D., H.H. Roberts, L.J. Rouse, Jr., and O.K. Huh. 1982. Thermal history of reefassociated environments during a record cold-air outbreak event. Coral Reefs 1:83-87.

Walker, N.D., L.J. Rouse, Jr., and O.K. Huh. 1987. Response of subtropical shallow-water environments to cold-air outbreak events: Satellite radiometry and heat flux modeling. Cont. Shelf Res. 7:735-757.

Walther, G.-R., E. Post, P. Convey, A. Menzel, C. Parmesan, T.J.C. Beebee, J.-M. Fromentin, O. Hoegh-Guldberg, and F. Bairlein. 2002. Ecological responses to recent climate change. Nature 416:389-395.

Wapnick, C., W.F. Precht, and R.B. Aronson. 2004. R.B. Millennial-Scale dynamics of staghorn coral in Discovery Bay, Jamaica. Ecol. Lett. 7:354-361.

Ward, F. 1990. Florida's coral reefs are imperiled. Natl. Geogr. Mag. 178:115-132.

Ward-Paige, C.A., M.J. Risk, and O.A. Sherwood. 2005. Reconstruction of nitrogen sources on coral reefs: $\delta^{15} \mathrm{~N}$ and $\delta^{13} \mathrm{C}$ in gorgonians from Florida Reef Tract. Mar. Ecol. Prog. Ser. 296:155-163.

Warzeski, E.R. 1977. Data relating to water and climatic conditions in the Florida Keys. In Field Guide to Some Carbonate Rock Environments Florida Keys and Western Bahamas, ed. H.G. Multer, 317-323. Dubuque: Kendall/Hunt.

Weiss, M.P., and D.A. Goddard. 1977. Man's impact on coastal reefs-An example from Venezuela. In Reefs and Related Carbonates-Ecology and Sedimentology, eds. S.H. Frost, M.P. Weiss, and J.B. Saunders, 111-124. Tulsa: American Association of Petroleum Geologists.

Wellington, G.M., P.W. Glynn, A.E. Strong, S.A. Navarette, E. Wieters, and D. Hubbard. 2001. Crisis on coral reefs linked to climate change. Eos 82:1, 5.

Wells, S., and N. Hanna. 1992. The Greenpeace Book of Coral Reefs. New York: Stirling. Wheaton, J.L., and W.C. Jaap. 1988. Corals and other prominent benthic cnidaria of Looe Key National Marine Sanctuary. Fla. Mar. Res. Publ. 43:1-25.

White, B., H.L. Curran, and M.A. Wilson. 1998. Bahamian coral reefs yield evidence of a brief sea-level lowstand during the last interglacial. Carbonates Evaporites 13:10-22. 
Wilkinson, C.R. 1993. Coral reefs of the world are facing widespread devastation: Can we prevent this through sustainable management practices? Proc. Seventh Int. Coral Reef Symp., Guam 1:11-21.

Wilkinson, C. (ed.). 2000. Status of Coral Reefs of the World: 2000. Cape Ferguson and Dampier: Australian Institute of Marine Science.

Wilkinson, C. (ed.). 2002. Status of Coral Reefs of the World: 2002. Cape Ferguson and Dampier: Australian Institute of Marine Science.

Wilkinson, C. (ed.). 2004. Status of Coral Reefs of the World: 2004. Cape Ferguson and Dampier: Australian Institute of Marine Science.

Williams, E.H., Jr., and L. Bunkley-Williams. 1990. The world-wide coral reef bleaching cycle and related sources of coral mortality. Atoll Res. Bull. 335:1-71.

Williams, E.H., Jr., and L. Williams. 2000. Marine major ecological disturbances of the Caribbean. Infect. Dis. Rev. 2:110-127.

Williams, I.D., and N.V.C. Polunin. 2001. Large-scale associations between macroalgal cover and grazer biomass on mid-depth reefs in the Caribbean. Coral Reefs 19:358-366.

Williams, I.D., N.V.C. Polunin, and V.J. Hendrick. 2001. Limits to grazing by herbivorous fishes and the impact of low coral cover on macroalgal abundance on a coral reef in Belize. Mar. Ecol. Prog. Ser. 222:187-196.

Wing, S.R., and E.S. Wing. 2001. Prehistoric fisheries in the Caribbean. Coral Reefs 20:1-8. Wood, R. 1999. Reef Evolution. New York: Oxford University Press.

Woodley, J.D. 1992. The incidence of hurricanes on the north coast of Jamaica since 1870: Are the classic reef descriptions atypical? Hydrobiologia 247:133-138.

Woodley, J.D., E.A. Chornesky, P.A. Clifford, J.B.C. Jackson, L.S. Kaufman, N. Knowlton, J.C. Lang, M.P. Pearson, J.W. Porter, M.C. Rooney, K.W. Rylaarsdam, V.J. Tunnicliffe, C.M. Wahle, J.L. Wulff, A.S.G. Curtis, M.D. Dallmeyer, B.P. Jupp, M.A.R. Koehl, J. Neigel, and E.M. Sides. 1981. Hurricane Allen's impact on Jamaican coral reefs. Science 214:749-755.

Zhou, Z., Y. Baoyin, and N. Petit-Marie. 1998. Paleoenvironments in China during the Last Glacial Maximum and the Holocene Optimum. Episodes 21:152-158.

Zubakov, V.A., and I.I. Borzenkova. 1990. Global Paleoclimate of the Late Cenozoic. Developments in Palaeontology and Stratigraphy 12. Amsterdam: Elsevier. 